\title{
اصطلاحات الأحكام في علم القراءات وفن الأداء بين المدلول الشرعي والاستعمال الصناعي
}

اصطلاهات الأهكام فيي علم القراءات وفز الأداء بين المدلول الشر عي

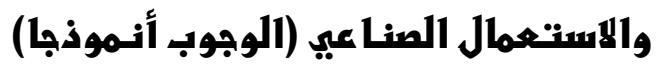

د. عبد الله محمد يوسف محمود("(

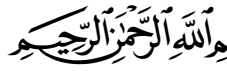

مقدمة

الحمد الله رب العالمين ، والصلاة والسلام على خاتم الأنبياء والمرسـلين،

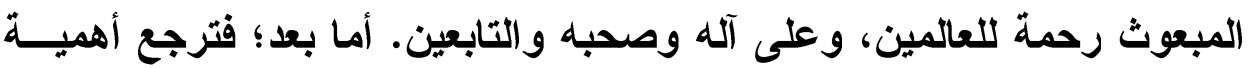

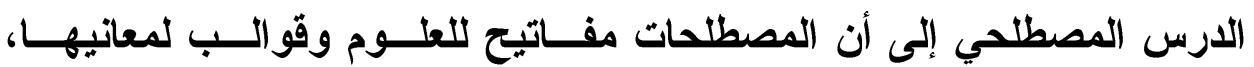

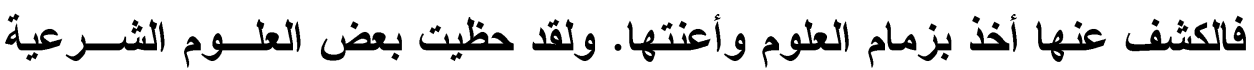

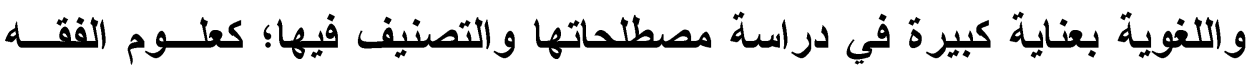
و الحديث والنحو وغيرها، ولم تحظ علوم أخرى بمثل ما حظيث بهابه هذه العلوم؛

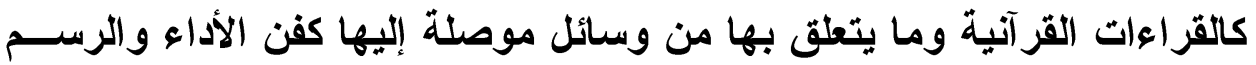
وعدّ الآي ونحوها.

ومن هنا كاتت الحاجة ماسة إلى إماطة اللثام عن خبايا المصطلح القرائسي

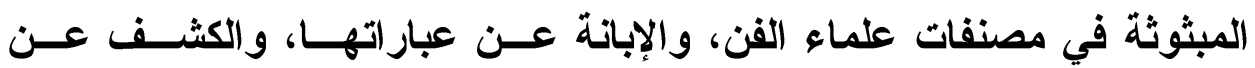

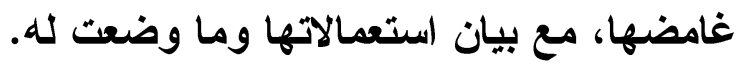

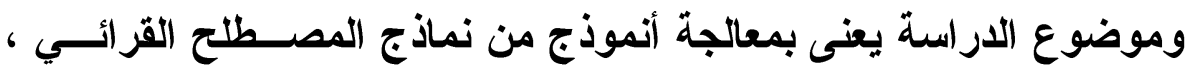

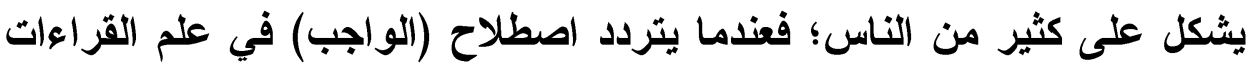

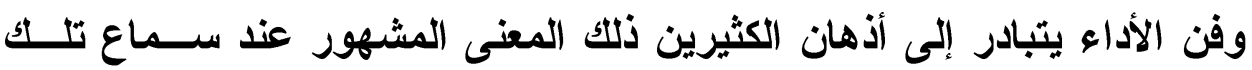
اللفظة؛ ألا وهو ما يلزم المكلفين فعله، وما يترتب على ذلك من إثابة الفاعـلــل

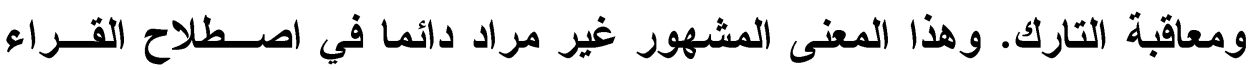

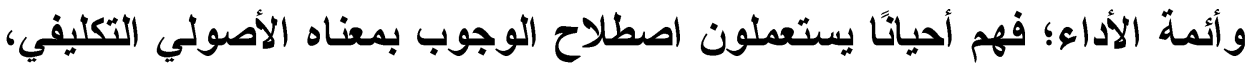


وأحيانًا أخرى بمعناه الأدائي الصناعي؛ لذا كان من الأهمية بمكان تسجيل وقفة

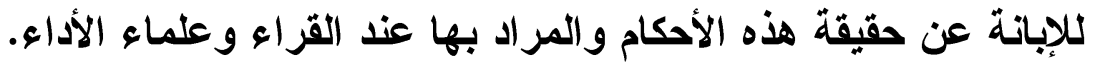

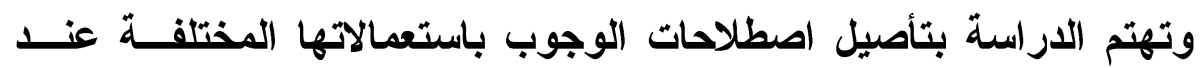

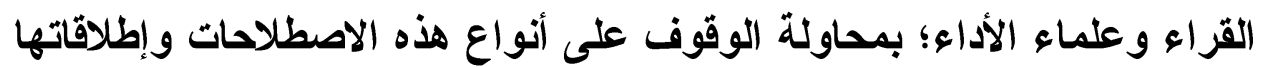
ومفاهيمها، مع مناقشة بعض النماذج التطبيقية لتلك الاصطلاحات؛ على سبيل

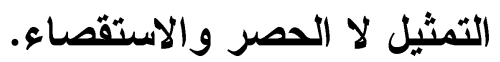

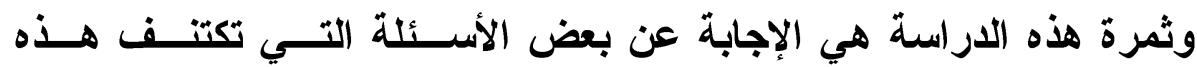

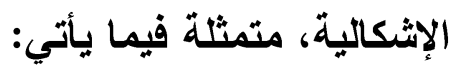

- ما مدى أهمية ضبط المصطلحات في علوم الثريعة وعلم القراعات؟

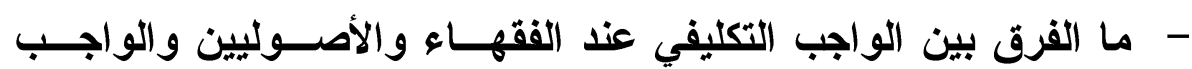
الأدائي الصناعي عند القراء وأئمة الأداء؟ أباء

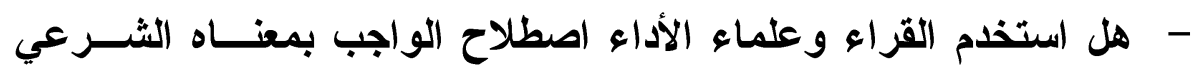

$$
\text { التكليفي }
$$

- ما أهمية هذه التفرقة المصطلحية في التطبيقات التي تناول فيها القراء

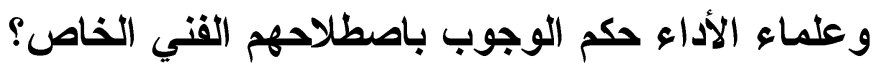

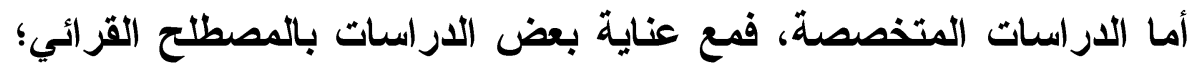

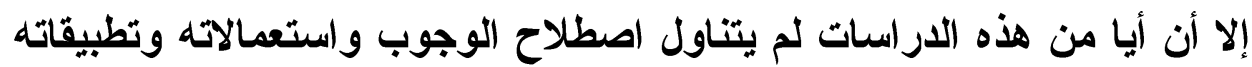

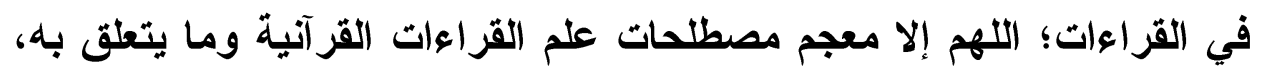

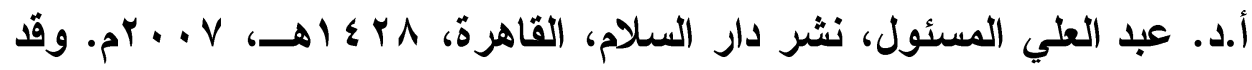
تناول فيه بعض تعاريف اصطلاح الوجوب دون أن يتعقب استعمالاته وأوجـهـ لوانه الفرق بينها، ولم يتعرض لتطبيقاته ونماذجه.

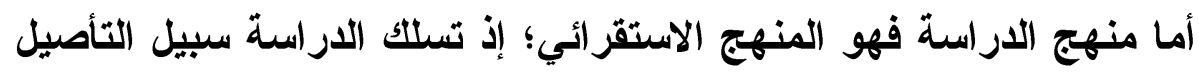

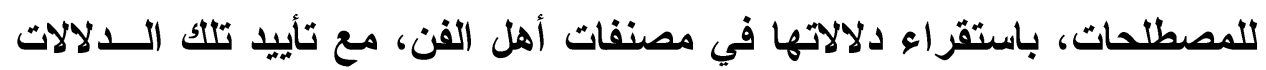

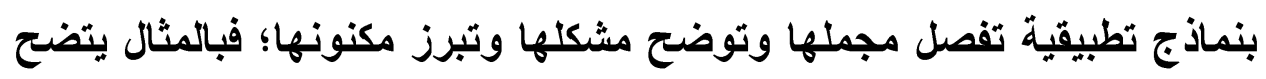
المقال. هذا وتقوم الار اسة على مقدمة وتمهيذ وثلاثة مباحث وخاتمة، على النحو 
اصطلاحات الأحكام في علم القراءات وفن الأداء بين المدلول الشرعي والاستعمال الصناعي

المقدمة : وفيها بيان أهمية الاراسة ودوافعها وأسئلتها والار اســات الســابقة

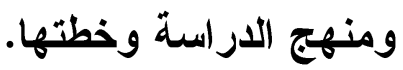

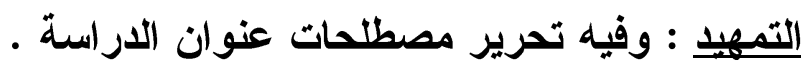

المبحث الأول : وهو بعنوان: المصطلح القرائي: أهميته والتأليف فيه، ويشتمل ماته على مطلبين:

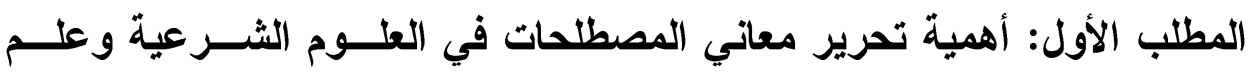

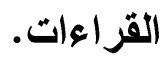

المطلب الثاني: التأليف في المصطلح القرائي قديمًا وحديثا.

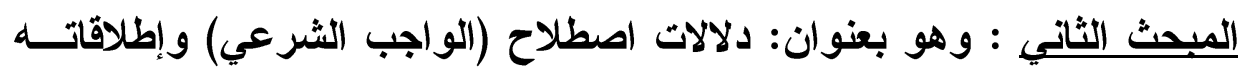
في علم القراءات وفن الأداء ، ويشتمل على ثلاثئة مطالب:

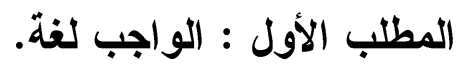
المطلب الثاني: الواجب التكليفي الثرعي وما يتعلق به عند الأصوليين. المطلب الثالث: الواجب التكليفي الثرعي عند القراء وعلماءو الألداء.

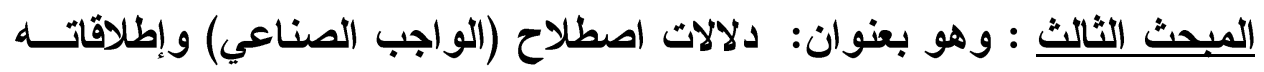
في علم القراعات وفن الأداء، ويشتمل على مطلى دلبين:

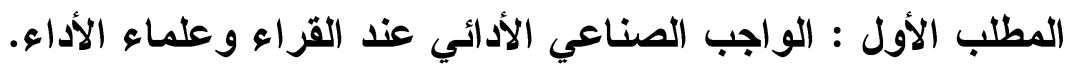

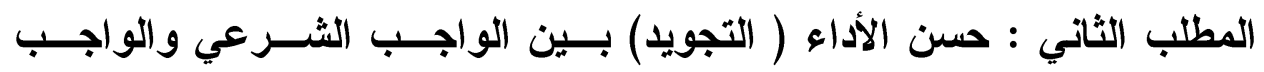
الصناعي.

وأخيرًا الخاتمة ؛ وبها أهم نتائج الدراسة وتوصياتها.

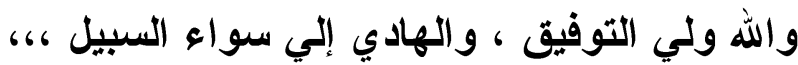

د. عبدالله محمد يوسف محمود 


\section{التمهيد}

إذا كان تحرير المصطلحات هو منطلق الدراسة ومبدؤها الأي تنبعث منه؛

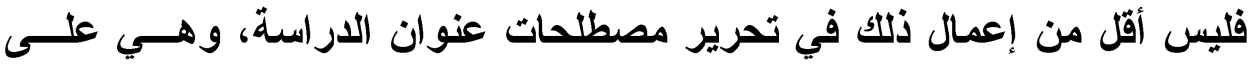
النحو الآتي.

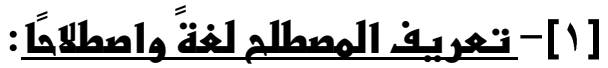

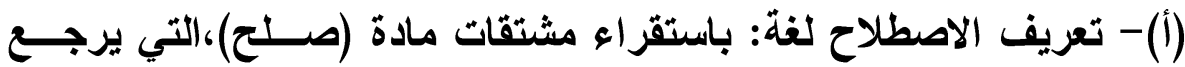

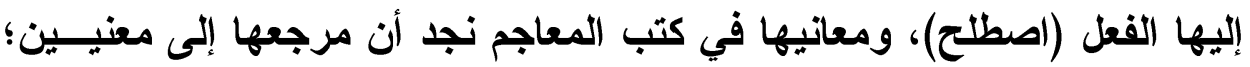

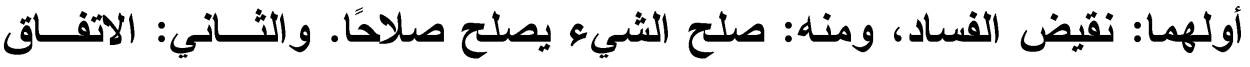

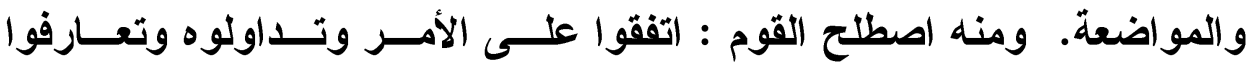
علبd (1)

والاصطلاح: اتفاق طائفة على شيء مخصوص؛ يقول ابن فارس في كتابه

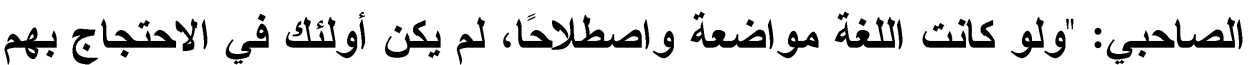

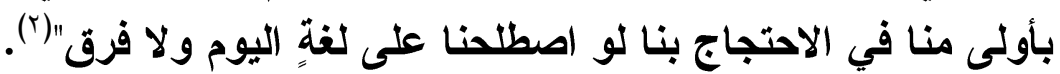

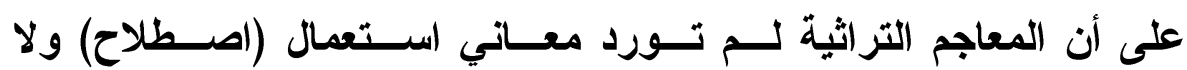

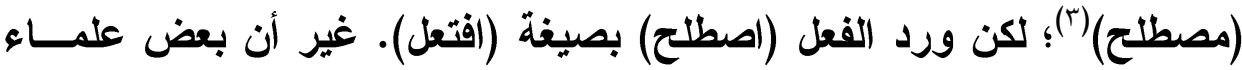

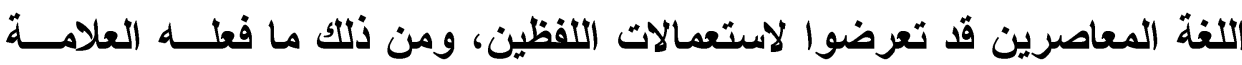

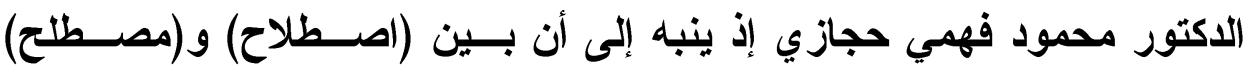

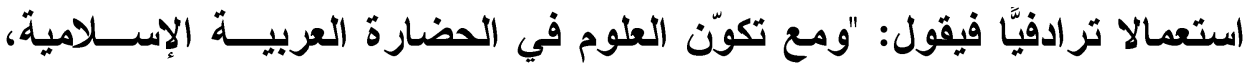

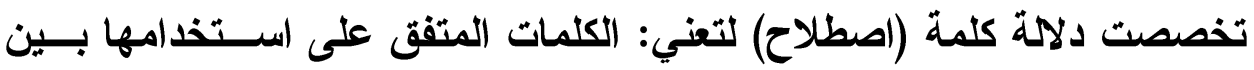

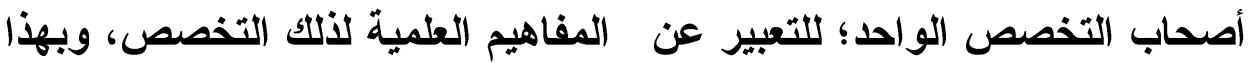

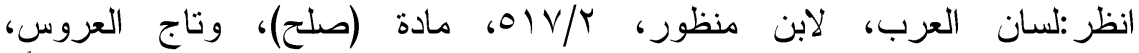

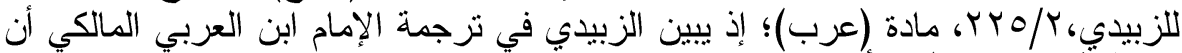

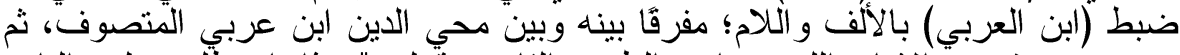

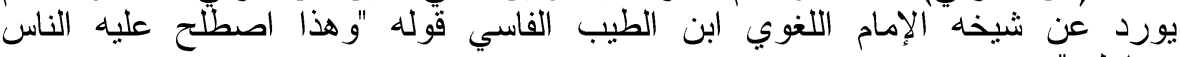

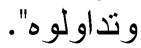

الصاحبي في فقه اللغة، لابن فارس ، ص ع عاولاه

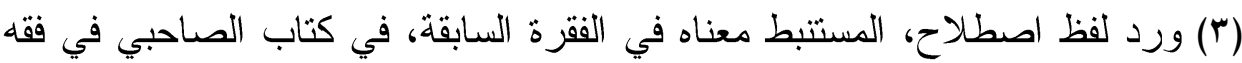
اللغة لابن فارس، وهو ليس من كتب المعاجم بل من كتب فقه اللغة كما فئن فئن عنو ان الكتاب ومضمونه. 
اصطلاحات الأحكام في علم القراءات وفن الأداء بين المدلول الشرعي والاستعمال الصناعي

المعني استخدمت أيضًا كلمة مصطلح"('). ويتبين مما قرره حجازي أن هذا من

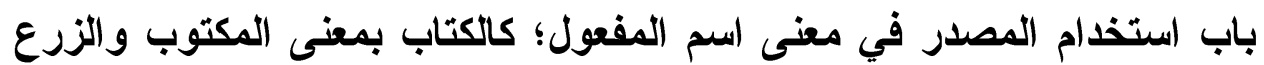
بمعنى المزروع.

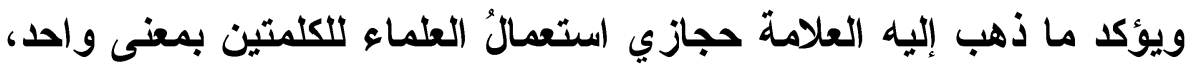

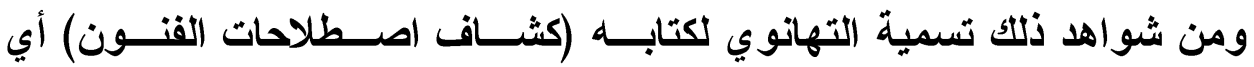

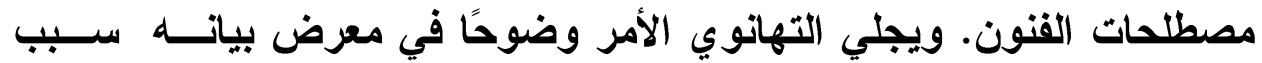

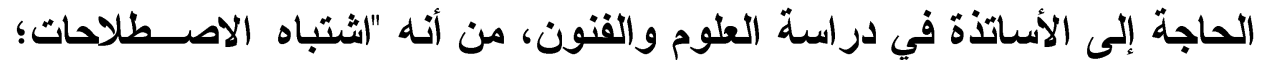

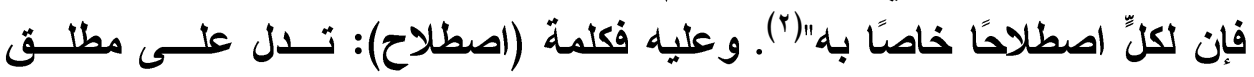

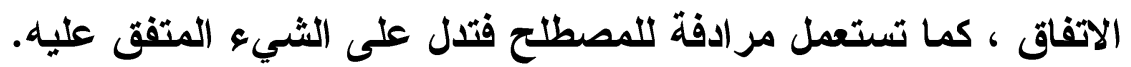

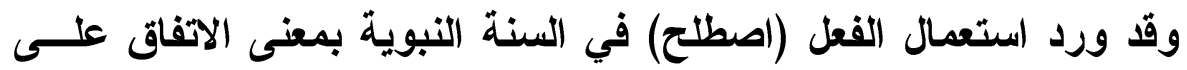

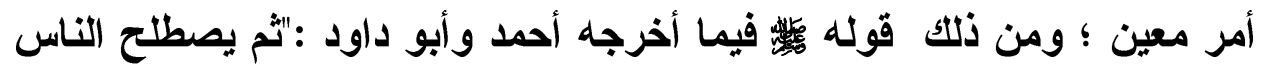

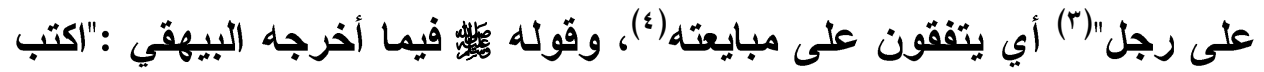

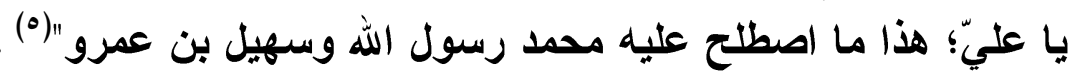

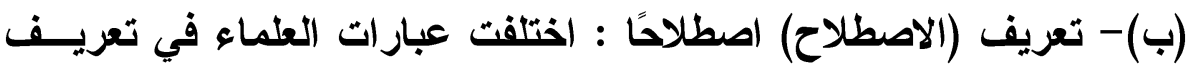
(الاصطلاح) ، فقد أورد الجرجاتي في (تعريفاته) خمسس تعريفــات مختلفــة

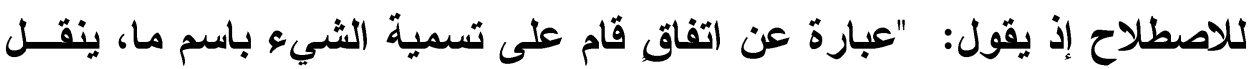

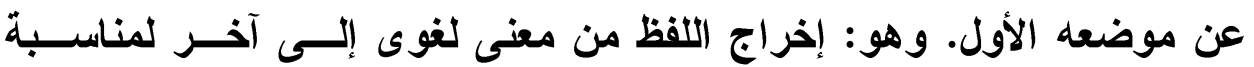
بينهما. وقيل الاصطلاح: اتفاق على وضع اللفظ باز اهول المعنى. وقيل الاصطلاح:

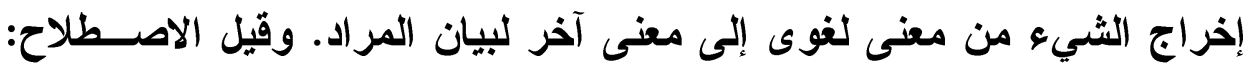

$$
\begin{aligned}
& \text { (1) الأسس اللغوية لعلم المصطلح ، د. محمود فهمي حجازي، ص } 1 \text { (باني }
\end{aligned}
$$

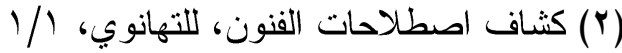

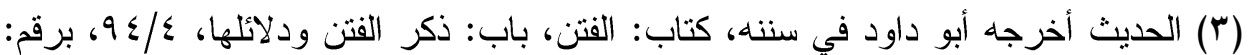

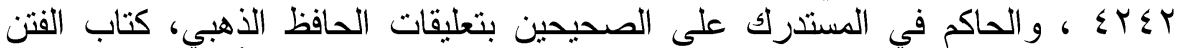

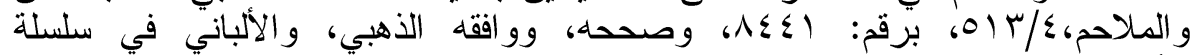

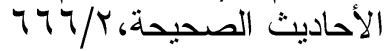

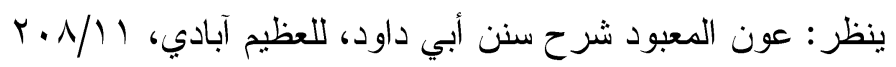

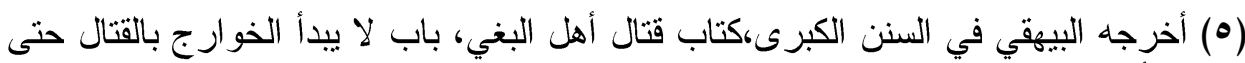

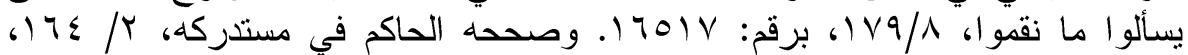


لفظ معين بين قوم معينين"(1). ويلاحظ أن التعريف الأخير للجرجاني يال على

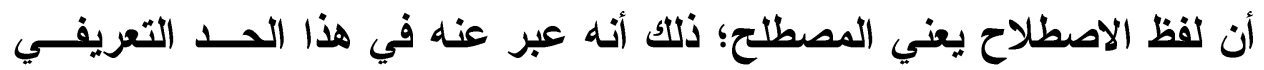
بقوله (لفظ معين) فليس المراد هنا الاتفاق؛ بل اللفظ الفظ المتفق عليه.

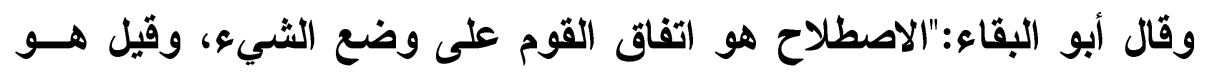

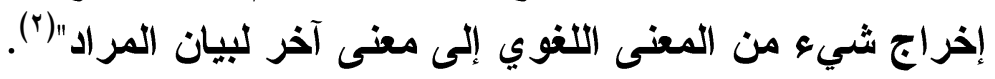

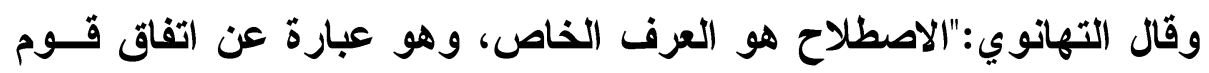

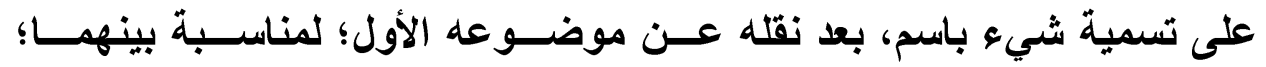

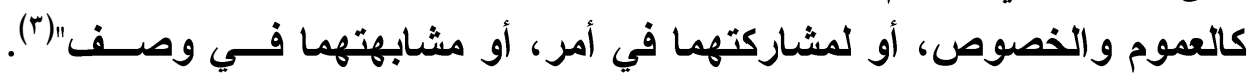

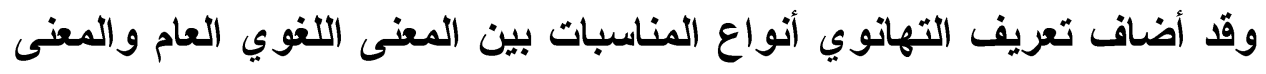
العرفي الخاص.

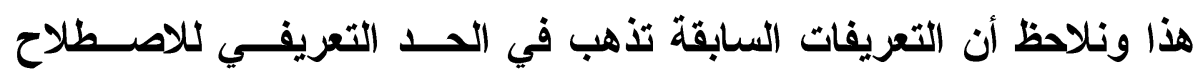

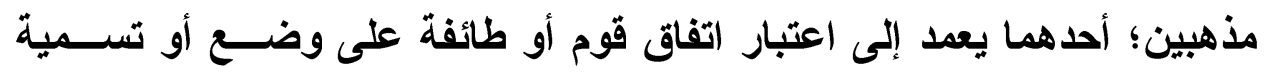

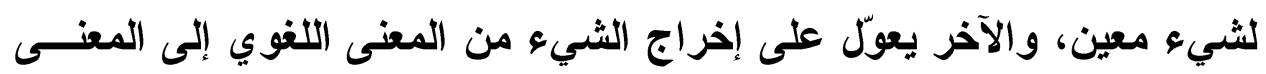
العرفي الخاص، وأرى أنه أدقهما.

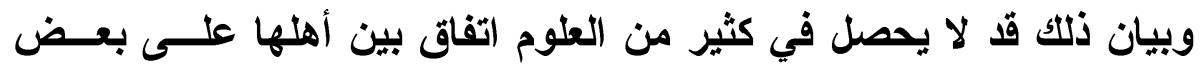

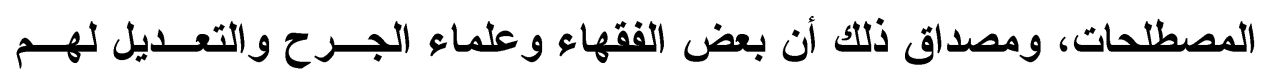

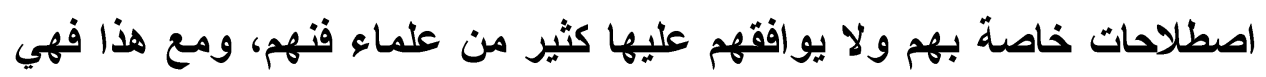
(مصطلحات) في هذا الفن، لكنها منسوبة إلى من قال بها. ويؤيد ذلك ما قرره

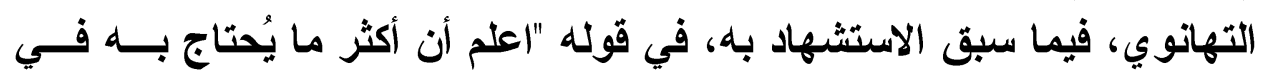

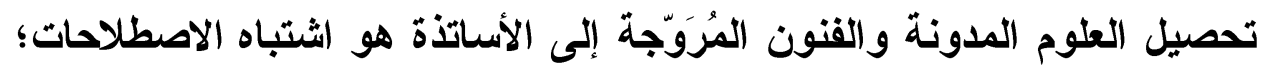

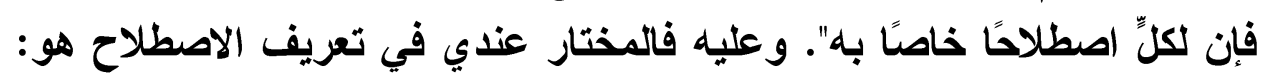

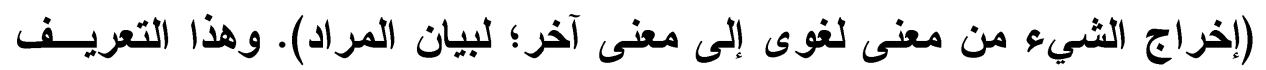
علاوة على دقته؛ فإنه قد أبان عن الغزئ من من استعمال الاصطلاح. 
اصطلاحات الأحكام في علم القراءات وفن الأداء بين المدلول الشرعي والاستعمال الصناعي

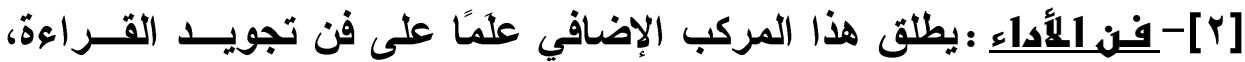

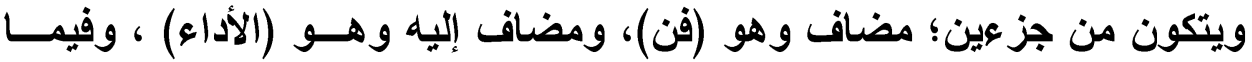

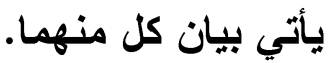
(أ)- الأداء لغة واصطلاحًا : أصل الأداء في اللغة الإيصال والقيام بالثيء؛

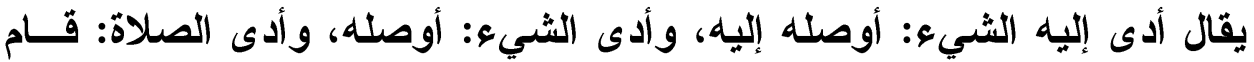

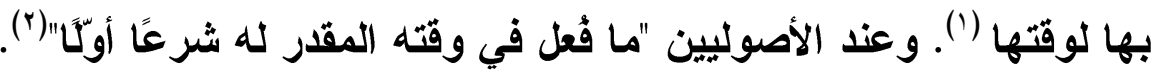

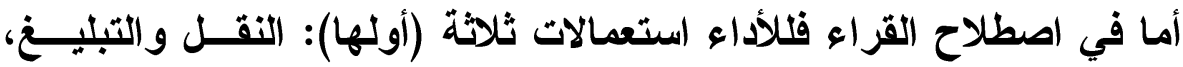

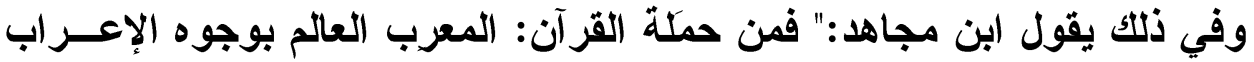

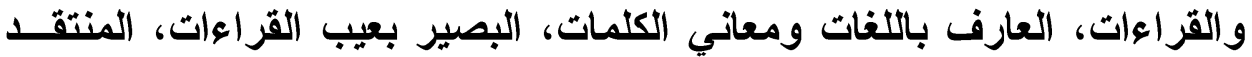

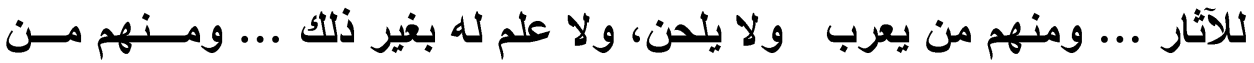

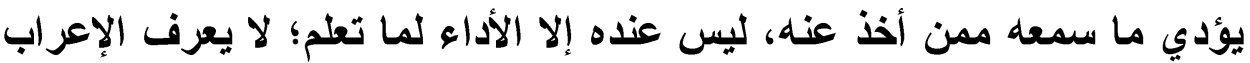

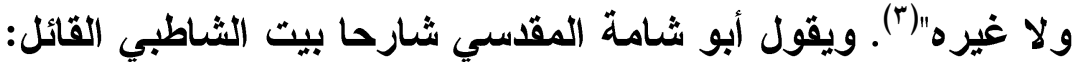

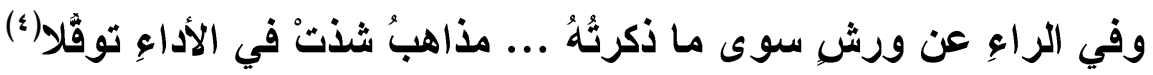

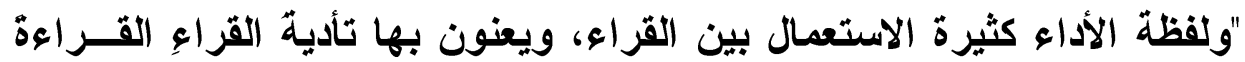

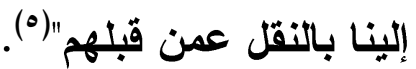
(وثانيها): الأخذ عن الثيوخ: قال في غاية النهاية في معرض ترجمة خلف

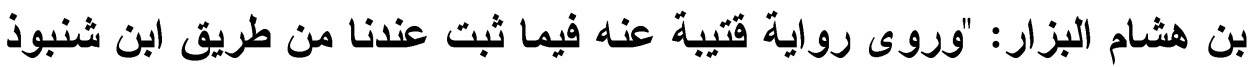

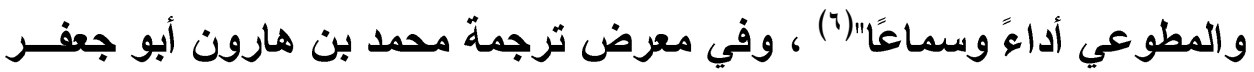

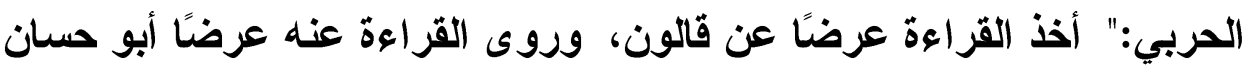

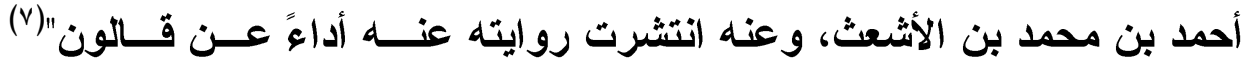

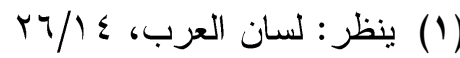

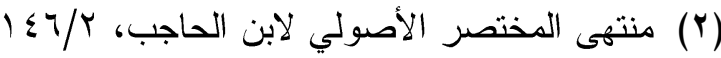

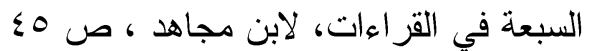

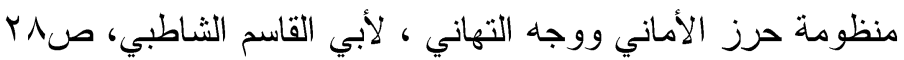

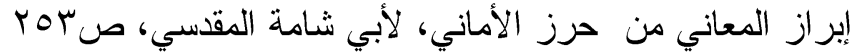

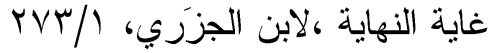

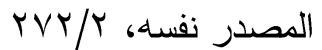


مجلة كلية الآداب، جامعة سوهاج، العدد السادس والأربعون، الجزء الأول، يناير 1 I • بم

وواضح من سياق الترجمة أنها تتناول طرق الرواية والأخذ عن الثيوخ، ومن

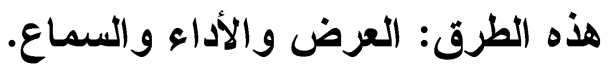

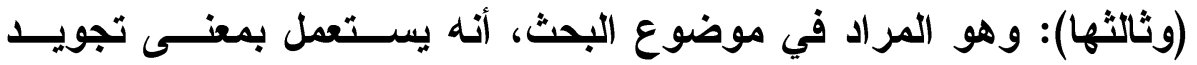
القراءة، وهو المهارة في إحكام مخارج الحروف وتحقيق صفاتها، ولذا يُةـــال

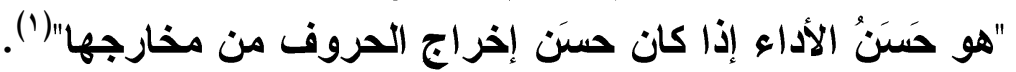

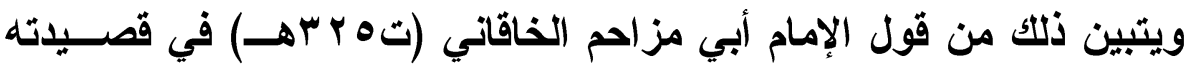
الخاقانية في البيت الخامس:

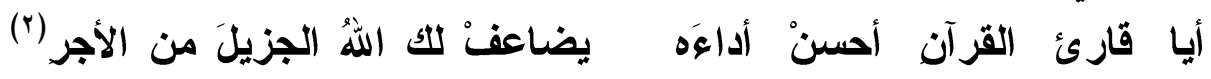
وفي البيث السابع عشر:

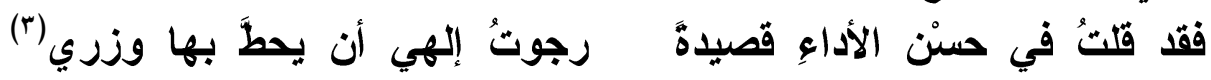
والقصيدة الخاقانية هي أول مؤلف وضع في علم التجويد كما يبين الدكتور

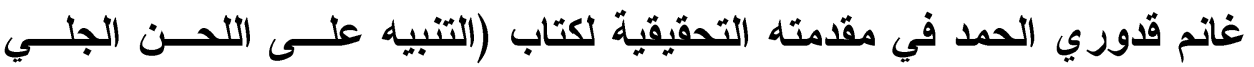
و اللحن الخفي) إذ يقول في معرض بيان الأهمية التاريخية للكتاب:"أما الناحيــة التئة

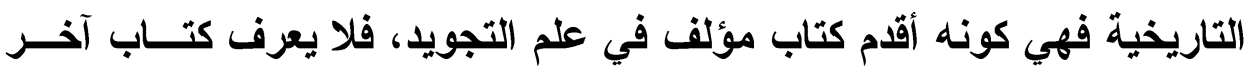
يسبقه في هذا المجال إلا القصيدة الخاقانية التي نظمها أبو مزاحم الخاقاني في

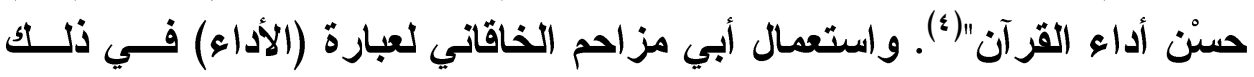

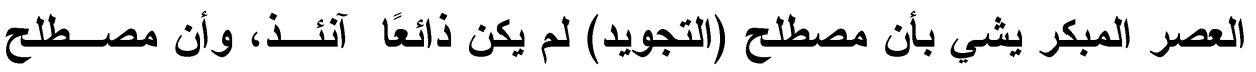
(الأداء) أقدم استعمالا.

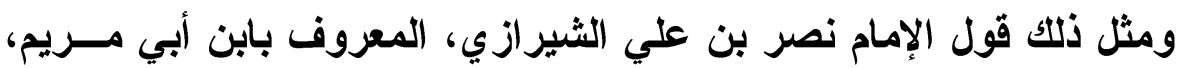

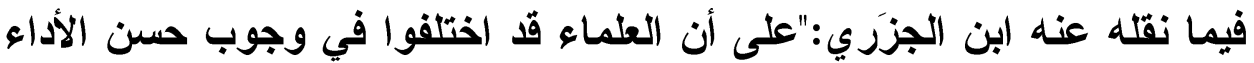

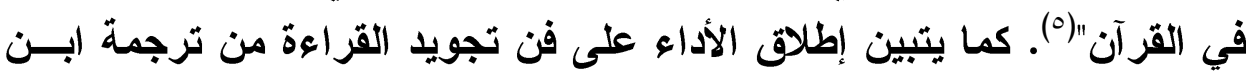

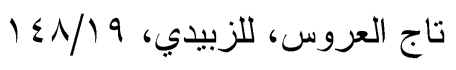

(Y) القصيدة حققها ونشرها الدكتور غانم قدوري الحمدي، ضمن الحن كتابه : أبحاث في علم

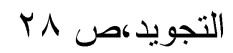

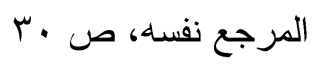

بحث بعنوان: (كتاب التنبيه على اللدن الجلي واللحن الخفي، لأبي الحسن علي بن بن جعفر

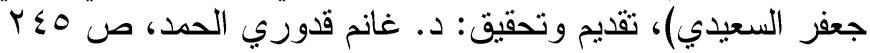

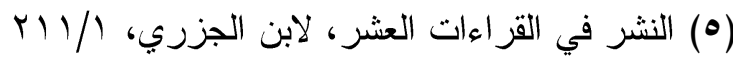


اصطلاحات الأحكام في علم القراءات وفن الأداء بين المدلول الشرعي والاستعمال الصناعي

الجزَري للإمام ورش إذ يقول : "مولاهم القبطي المصري، الملقب بورش، شيخ

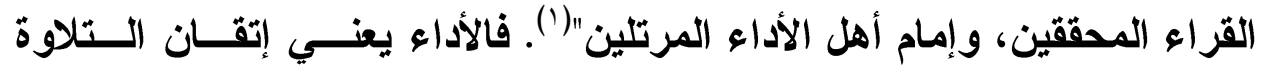
والترتيل. ويقول عن مطرّف بن عبد الرحمن :" وله كتاب حسن في الأداء"(؟).

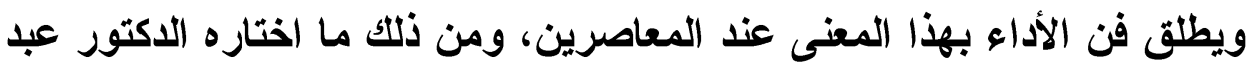

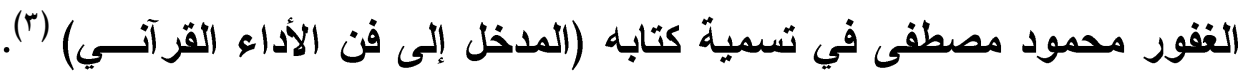

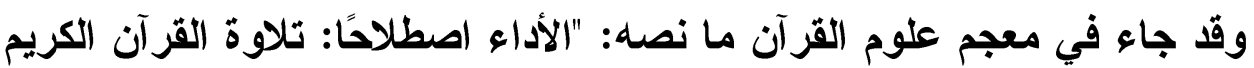
وتجويده وفق القواعد والأصول التجويدية المصطلح عليها بين القراء" أ(أ)

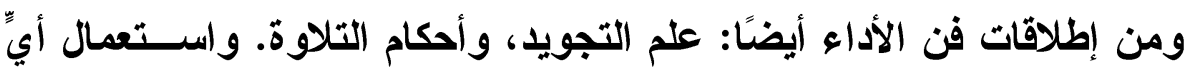

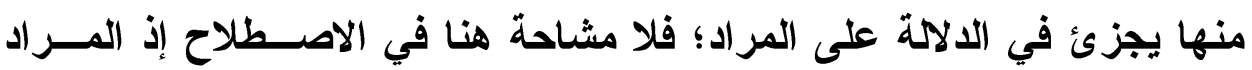
واحد.

(ب)- وجه تسميته فنَّا : أما وجه تسميته فنا، فله اعتبـــاران: (أحســهما) إطلاق الفن بمعني العلم توسعًا، وعلى هذا درج كثير من العلماء، ومن شواهئه أهد ذلك قول السيوطي عن صفات المجدد:

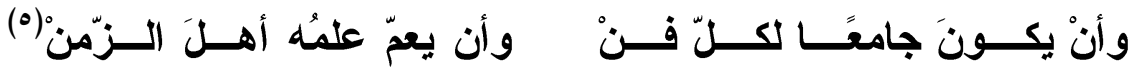

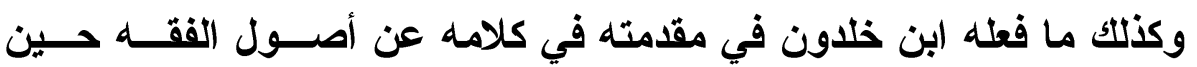

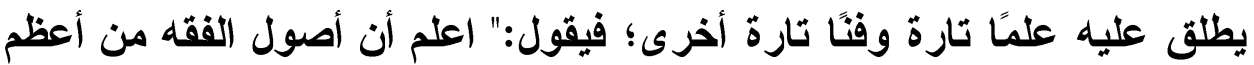

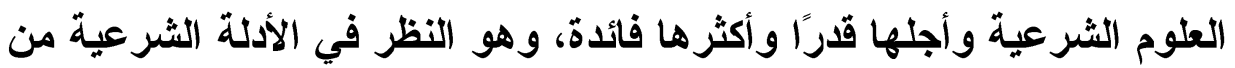

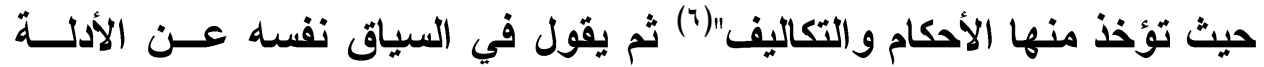

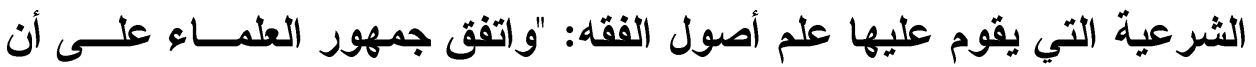

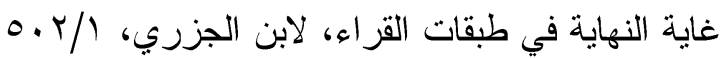

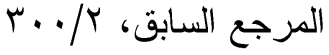

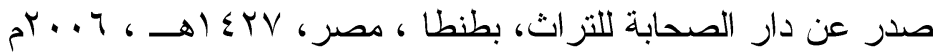

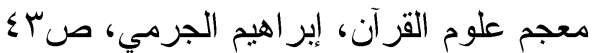

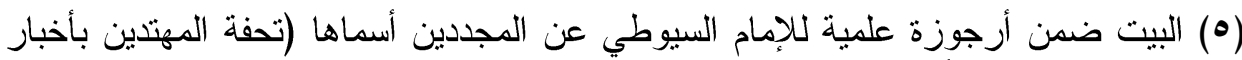

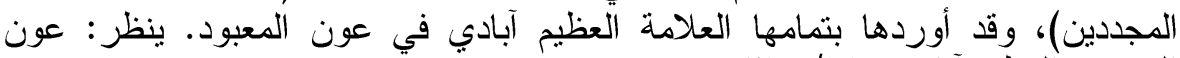

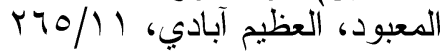

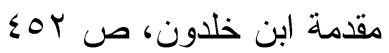


هذه هي أصول الأدلة، وإن خالف بعضهم في الإجماع و القياس ، فكان من أول

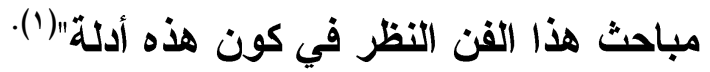

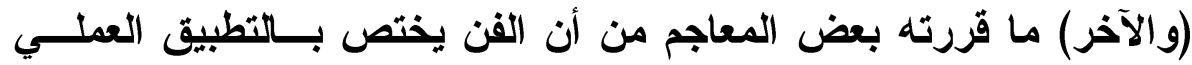

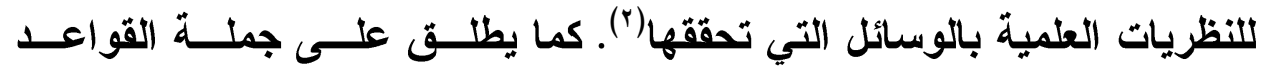

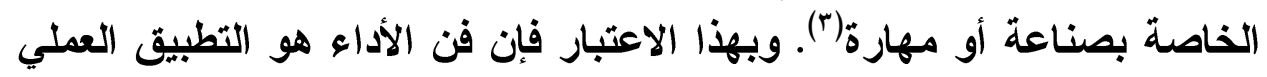

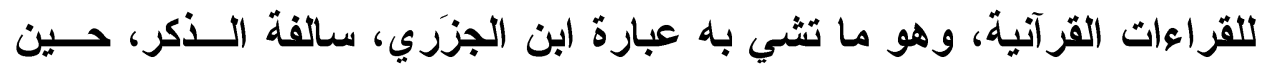

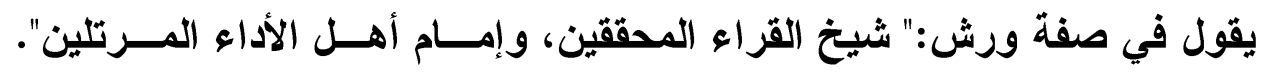

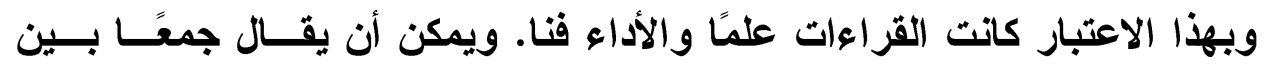
الاعتبارين إن الفن هو علمّ تطبيقي. [ץ] - الاستعمال الصناعي (الصناعة والصنعة) : تطلق الصناعة على التفنن

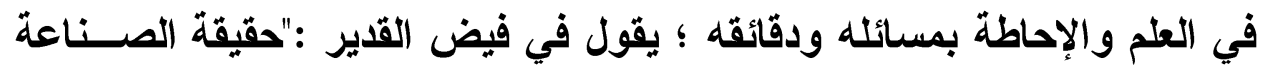

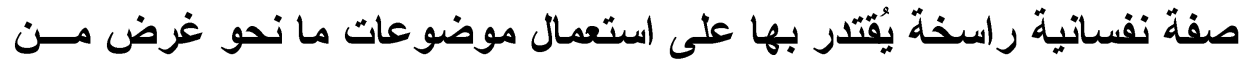

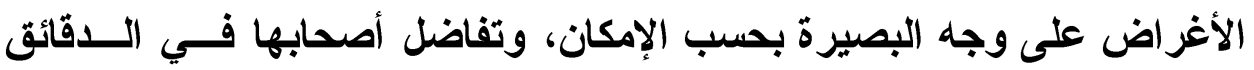

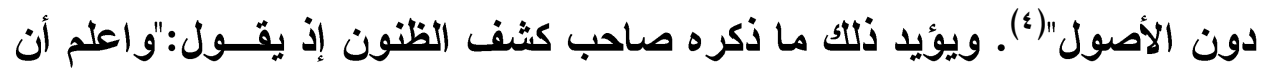

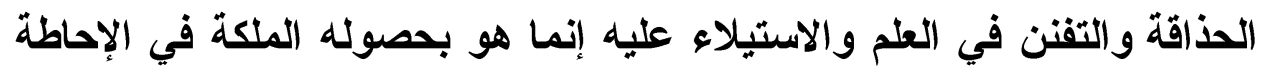

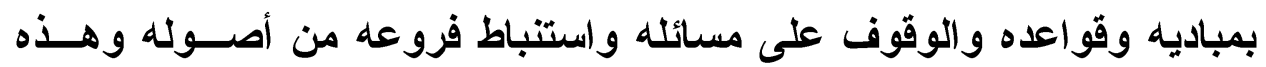

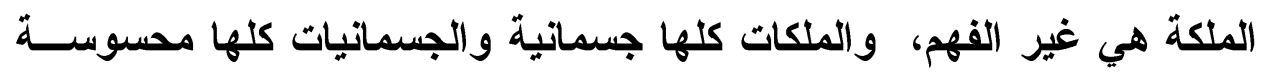

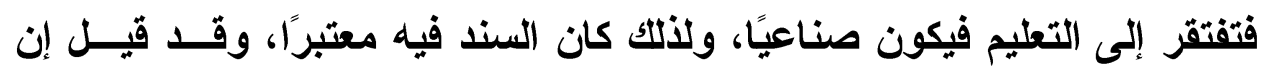

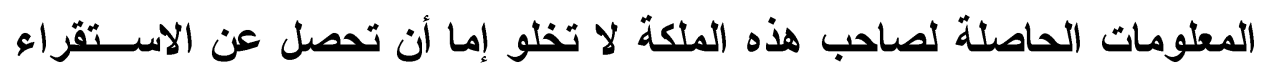

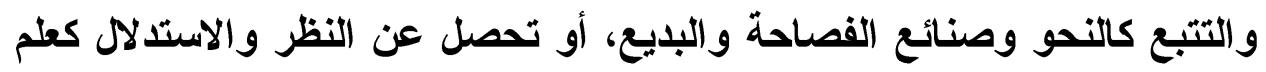

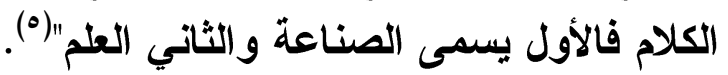

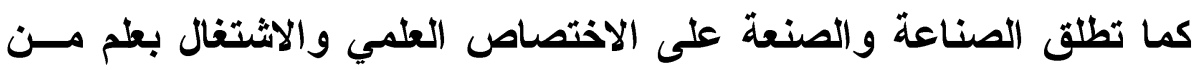

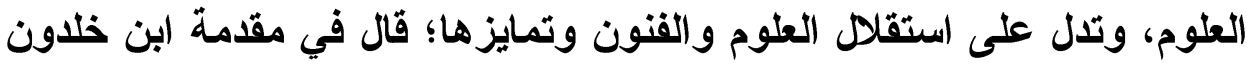

$$
\begin{aligned}
& \text { المصدر نفسه، ص ror }
\end{aligned}
$$

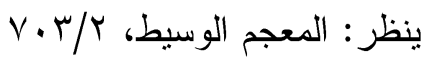

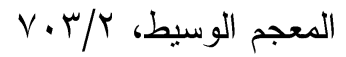

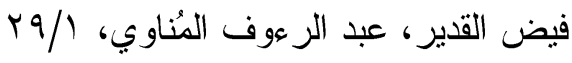

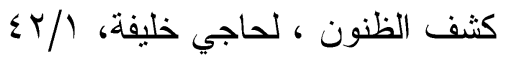


اصطلاحات الأحكام في علم القراءات وفن الأداء بين المدلول الشرعي والاستعمال الصناعي

في معرض كلامهه عن نشأة أصول الفقه: "فلما ذهــب الصــــر الأول وانقلبــ

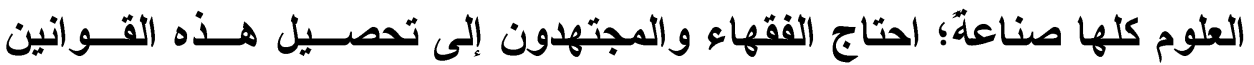

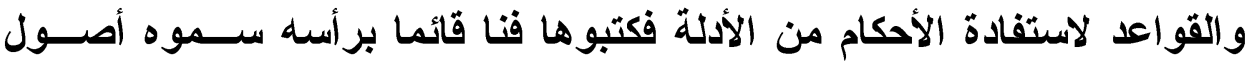
الفقه"('). وجاء في فيض القدير "والحق أن كل علم مارسه الإنسان سواء الأ كان

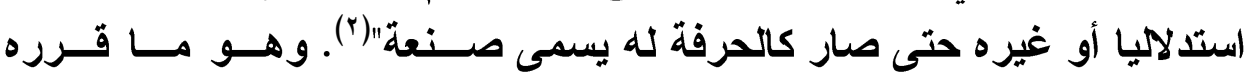

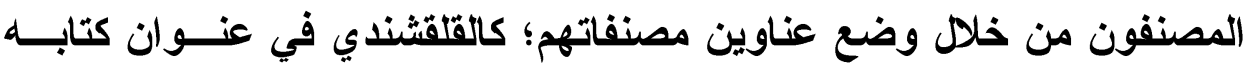

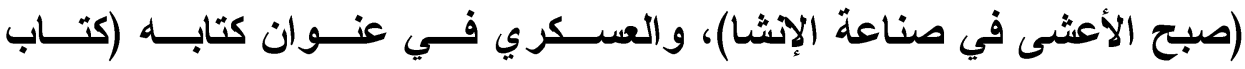
(الصناعتين: النظم والنثر).

والمقصود من (الاستعمال الصناعي) في هذا البحث: استعمال (الوجــوب)

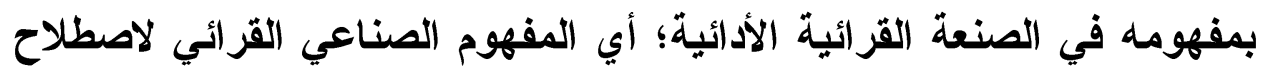

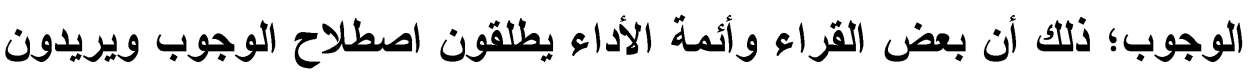

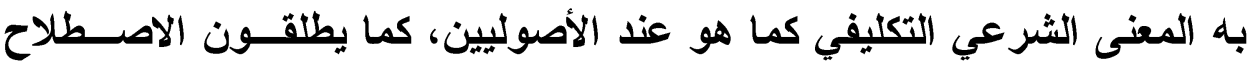

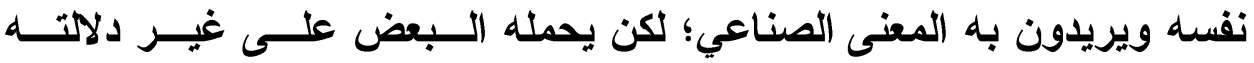
الصناعية. ومن ثم يهدف البحث إلى التفريق بين الاستعمالين.

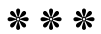

\section{المبــin}

المصطلح القرائي: أهميته والننأليف فيه

المطلب الأول : أهمية تحربر معانيى المصطلحات في العلوم الشر عية وعلم

1لقراءات :

يعد الاهتمام بالمصطلح ضرورة منهجية في العلوم الثرعية؛ ذلك أنه يعنى

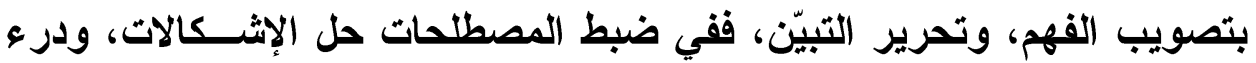

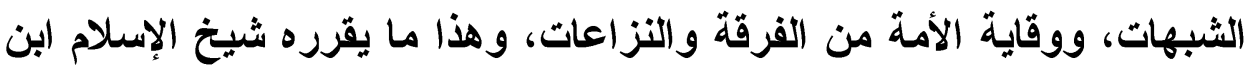

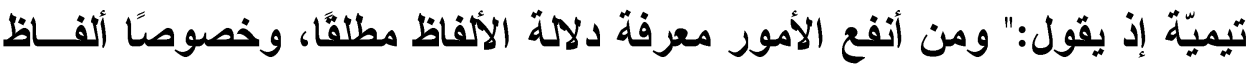

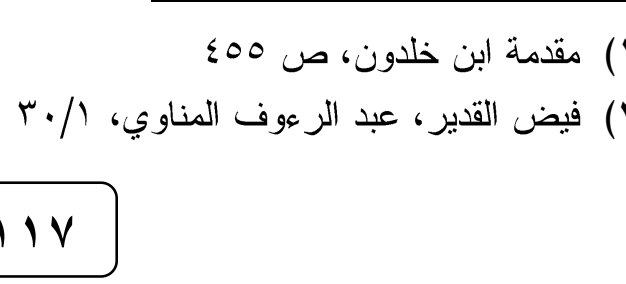


الكتاب والسنة، وبه تزول شبهات كثيرة، كثر فيها نزاع الناس، مسن جملتهــا

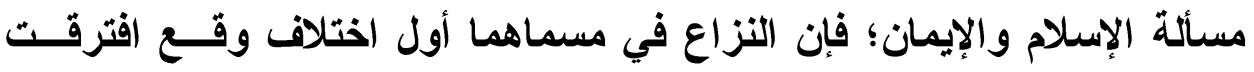

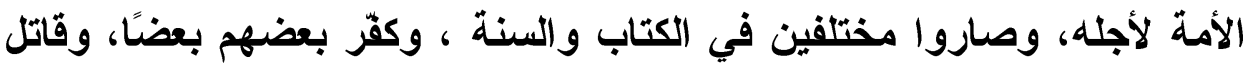

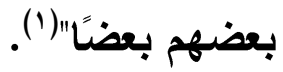
لذا نجد القرآن العظيم يولي عناية كبيرة بالمصطلح، فيؤدب المؤمنين بأن يستعملوا الكلمات الواضحة التي لا لبس فيها؛ حتى لا يستفلها المبطلون مجالا

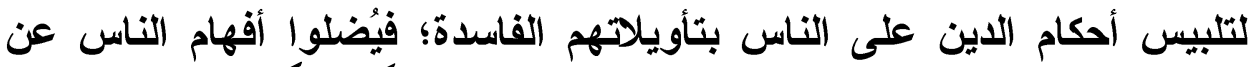

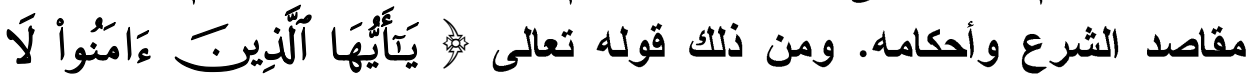

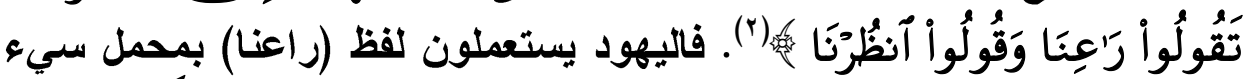

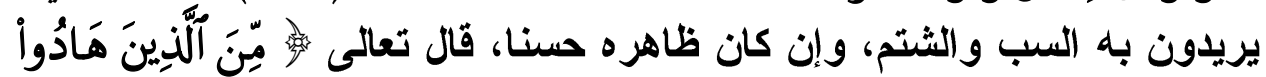

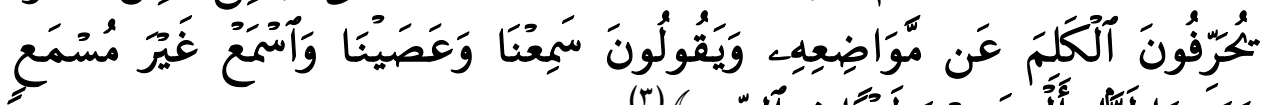

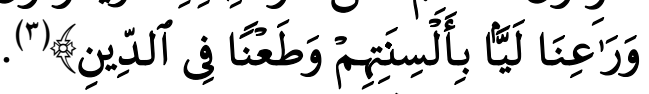

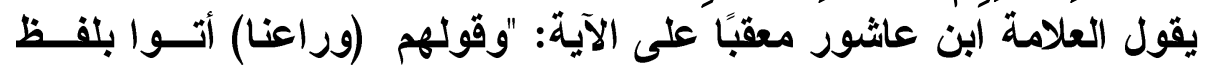

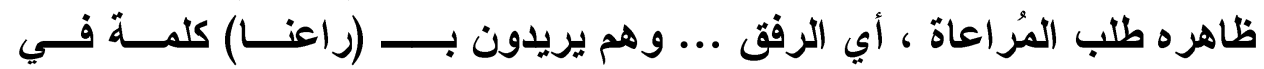

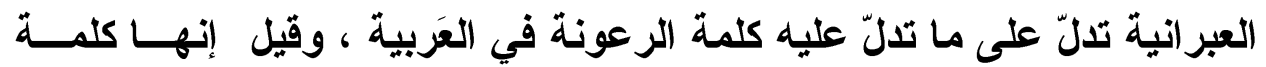

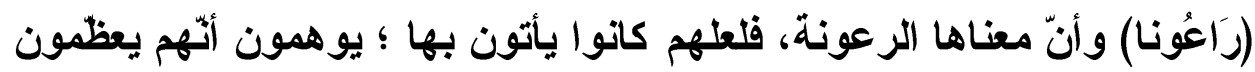

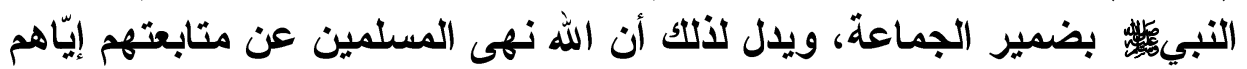

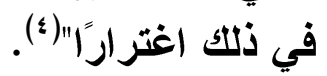

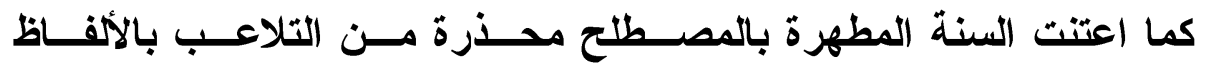

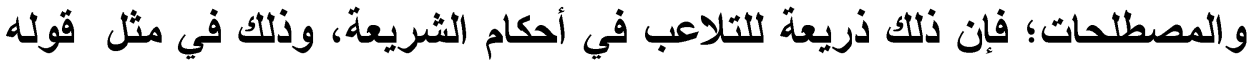

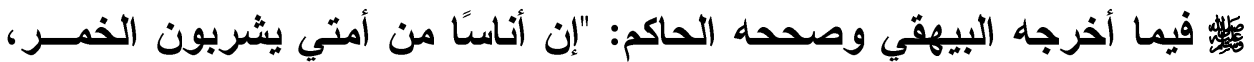

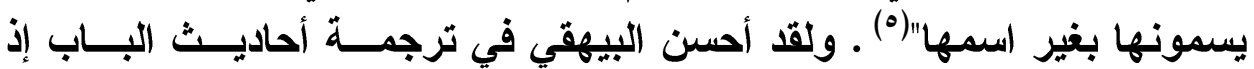

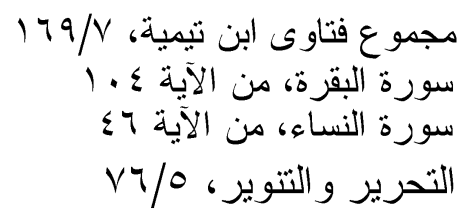

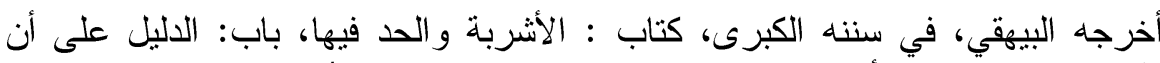

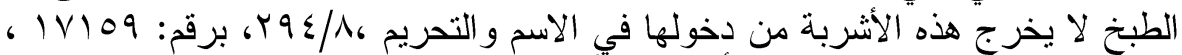

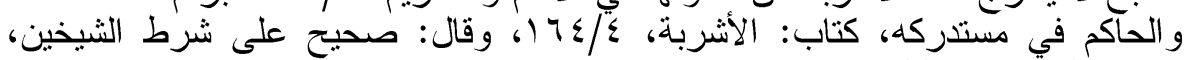


اصطلاحات الأحكام في علم القراءات وفن الأداء بين المدلول الشرعي والاستعمال الصناعي

يقول:" باب الاليل على أن الطبخ لا يخرج هذه الأشربة من دخولها في الاســـ

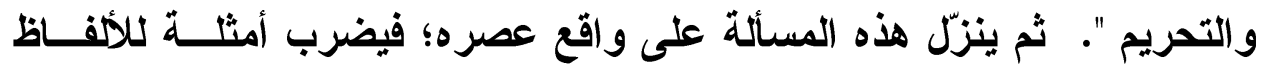

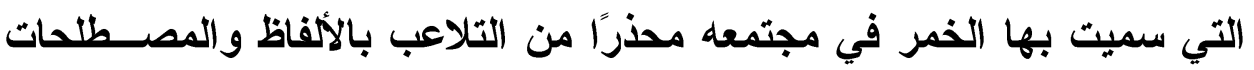

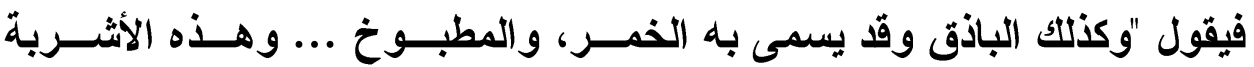

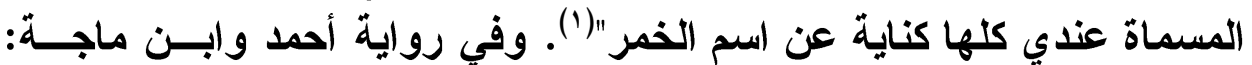

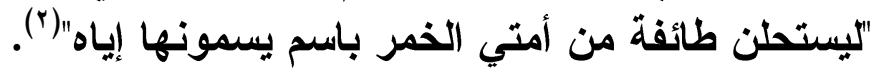
ومصداق ما تتبأت به السنة النبوية ما نراه في الفمب عصرنا الحاضر من تسمية

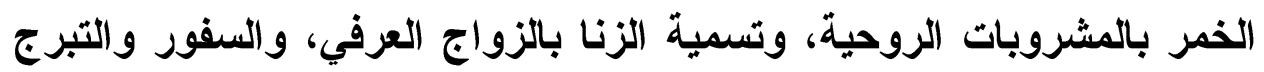

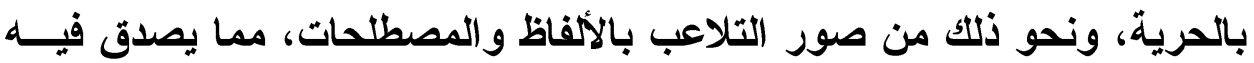

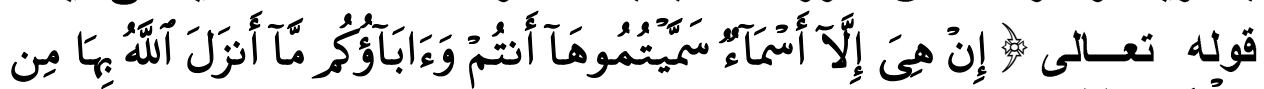

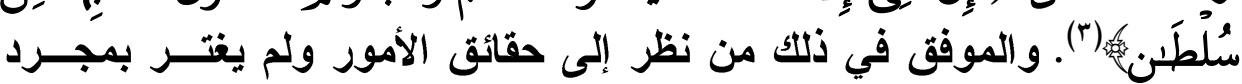

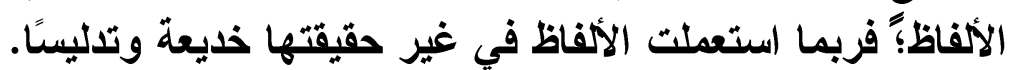

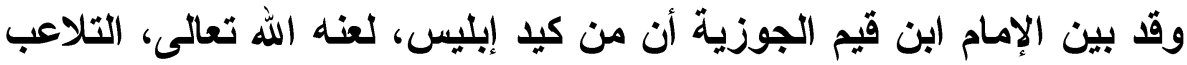

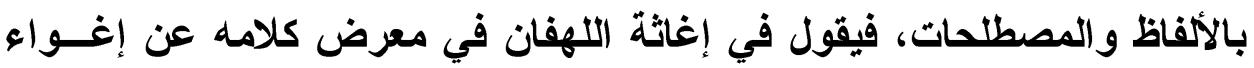

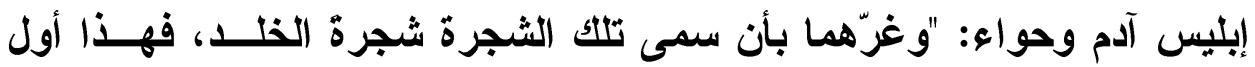

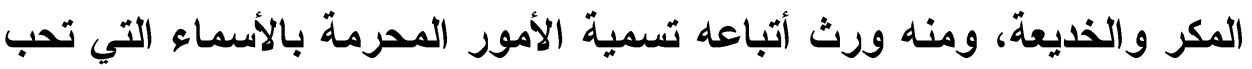

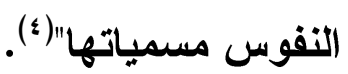

ويتبين مما قررته نصوص الكتاب والسنة خطورة المصطلح وأهميته ؛ ذللك

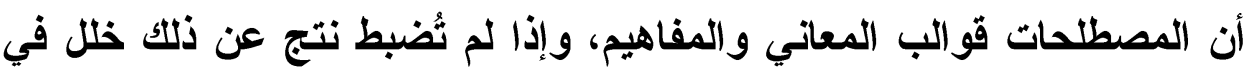

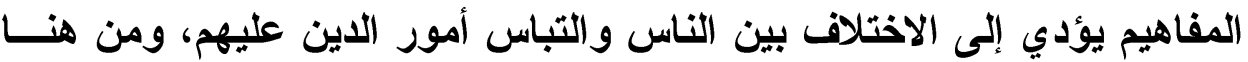

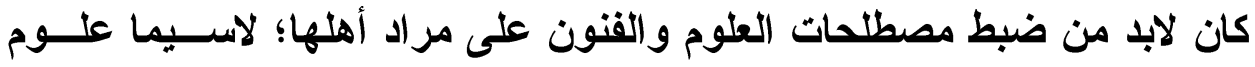

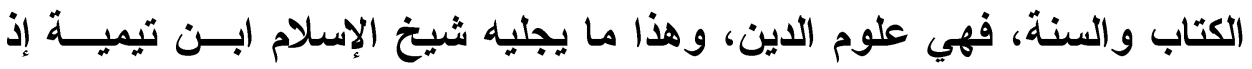

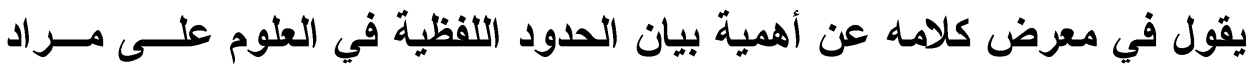

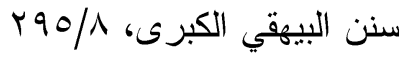

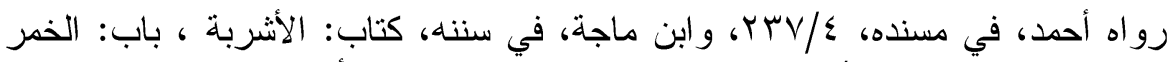

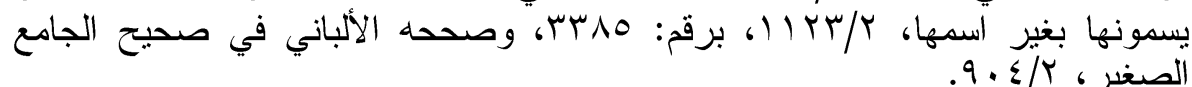

سورة النجم، من الآية سبك

إغاثة اللهفان من مصائد الثيطان، لابن قيم الجوزية، / II/ 
أهلها: "فأنان المقصود ذكر مراد المتكلم بتلك الأسماء، وهذا الحد هـــم متفةـــون

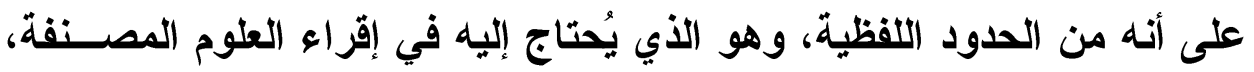

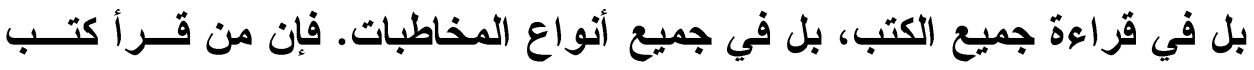

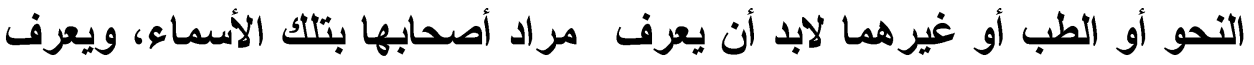

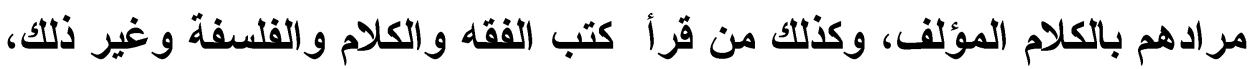

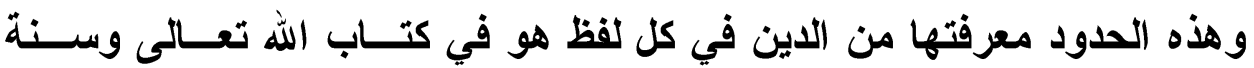

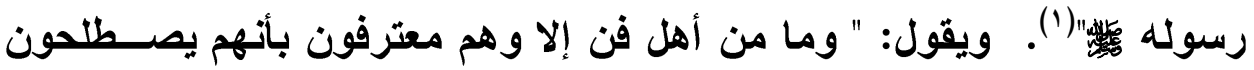

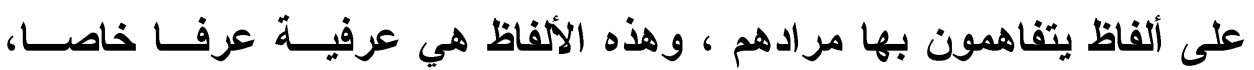

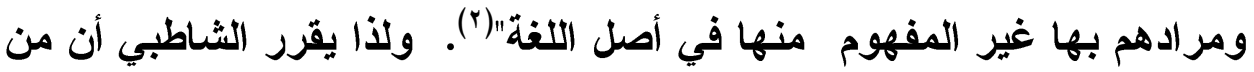

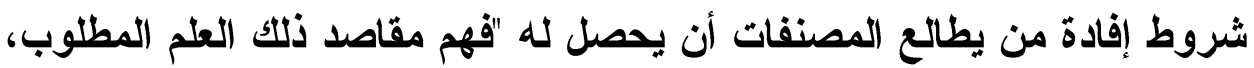

ومعرفة اصطلاحاث أهله" ("آ.

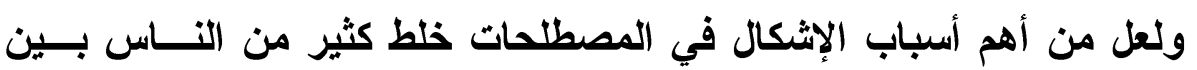
مفهوم شرعي واصطلاح أحدثه أرباب العلوم والفنون؛ فيلتبس عليهم الأمر بين

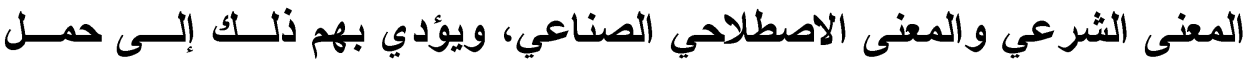

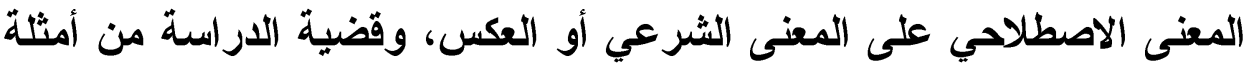
هذا الإشكال في المصطلح القرائي.

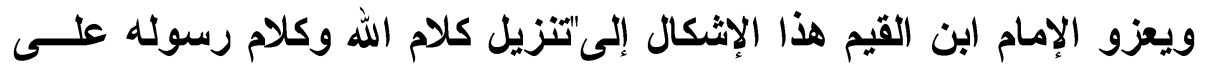
الاصطلاحات التي أحدثها أرباب العلوم، من الأصوليين، والفقهاء، وعلم الأئمال أحوال

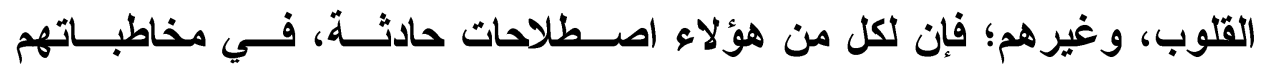

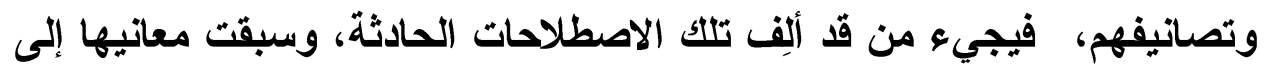
قلبه فلم يعرف سواها، فيسمع كلام الشارع فيحمله على ما ألفِه من الاصطلاح؛

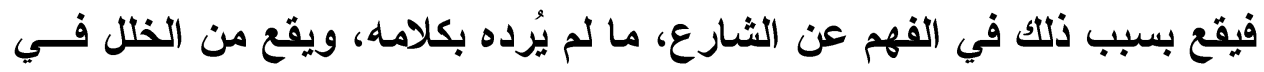
نظره ومناظرته ما يقع، وهذا من أعظم أسباب الغلط "( أ).

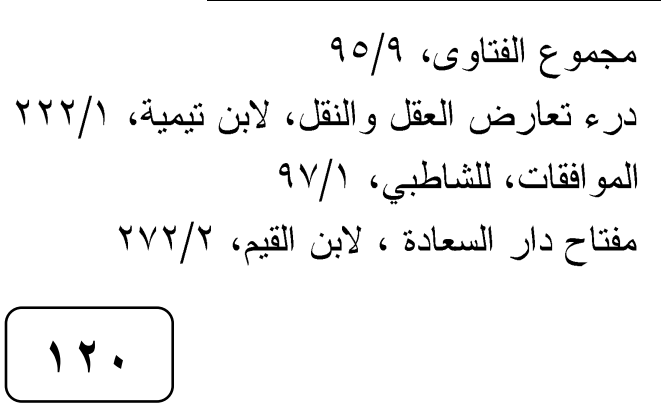


ومن هنا تبرز أهمية الدرس المصطلحي القرائي في توضيح ما أثكل على

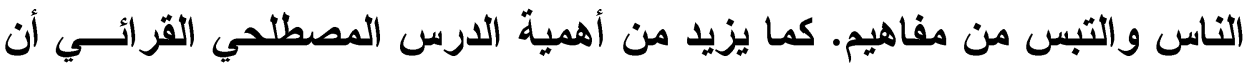

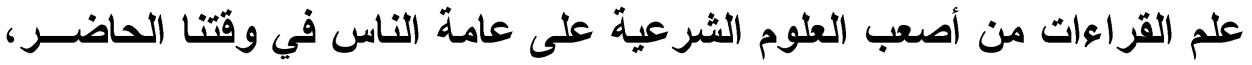

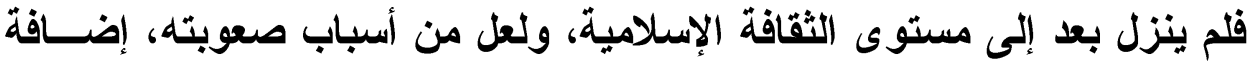

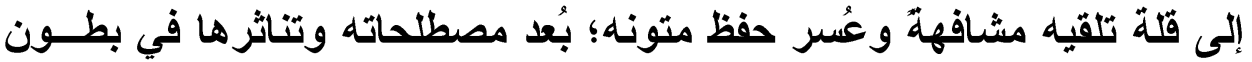

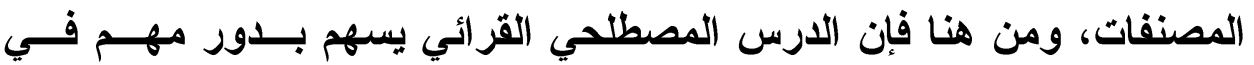
تقريب القراعات وتهذيبها، فللمصطلحات دور رئيس في تجديد العلوم وتقريبها،

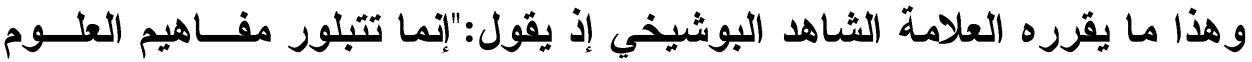

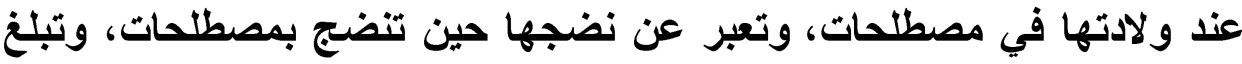
أثدها حين تبلغه بأنساق من المصطلحات، ولا سبيل إلى تجديد أي علــــ دون

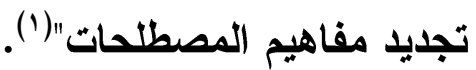

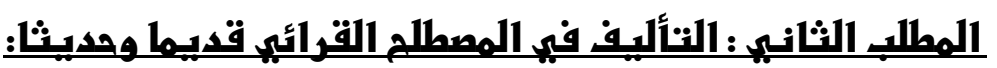
لا تكاد تخلو تضاعيف مصنف من مصنفات علوم القراعات والتجويد مسن

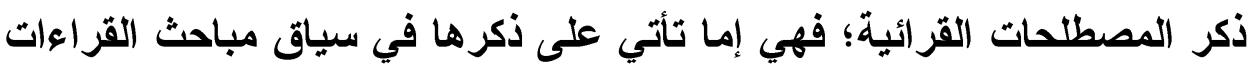

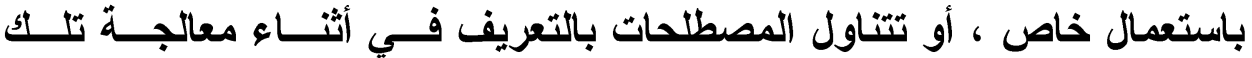
المباحث.

غير أن بعض المؤلفات قد عنيت بالمصطلح القرائــي عنايـــة خاصـــة؛ إذ إذ تمحضت لبيان المصطلح القرائي وتوضيح علائق بعض المصطلحات بــبعض، وما تندرج تحته المصطلحات من أصول القراعة، ومن أهم هذه المؤلفات:

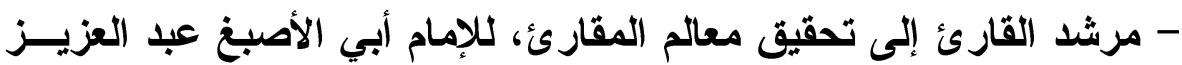

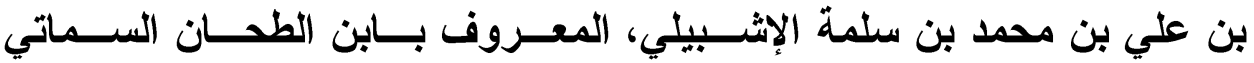

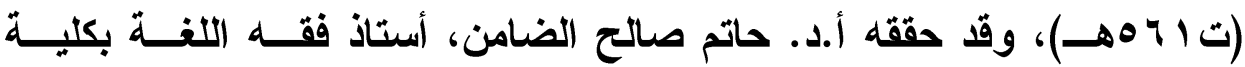

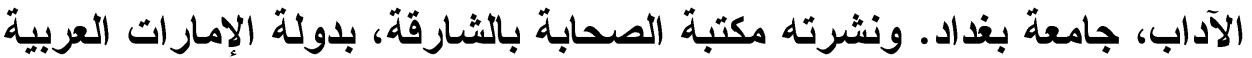

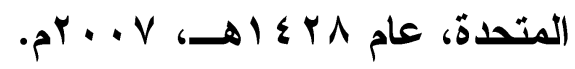

والكتاب يتألف من مقدمتين؛ أولاهما مقدمة في التجويد؛ ضمّنها المؤلــف

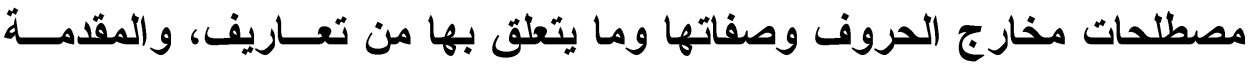

$$
\text { (1) نظرات في المصطلح و المنهج، د. الثاهد البوشيخي، ص } 10
$$




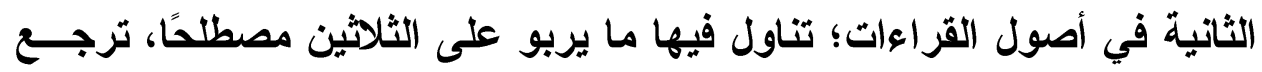

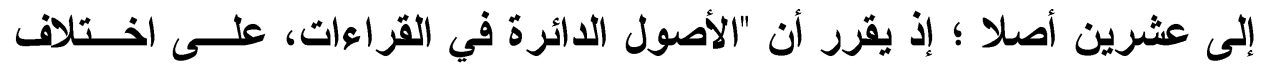

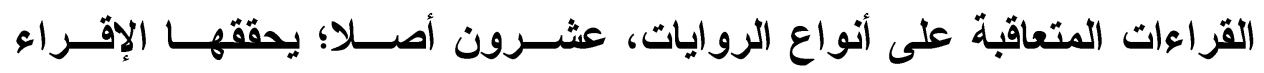
ويُحكمها الأداء" (1).

- القواعد والإشـارات في أصول القراعات، للإمام أحمد بن عمر الحمــوي

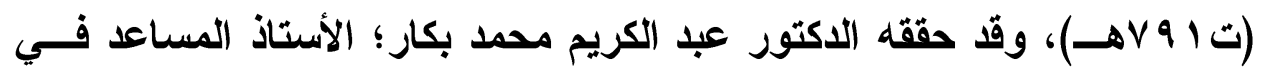

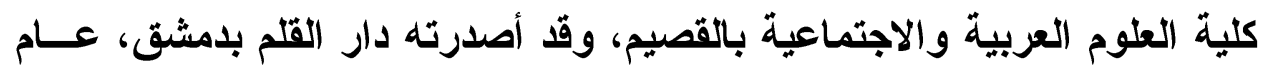

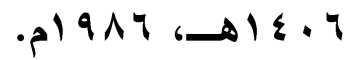
وقا عالج فيه الحمويّ ما يربو على الأربعين مصطلحا؛ تندرج في اثنـين

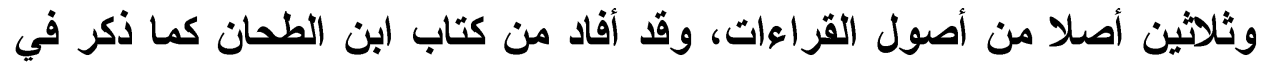

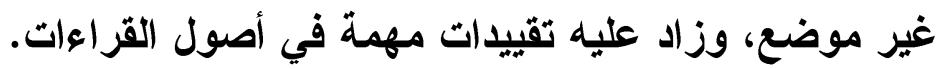

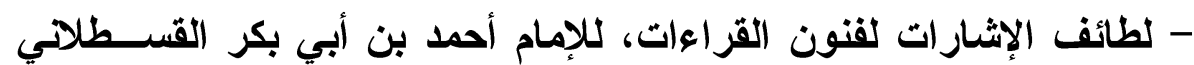

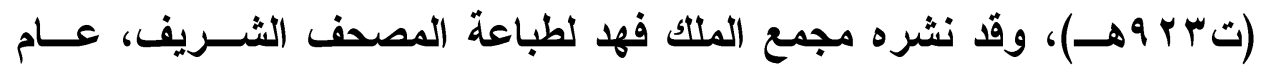

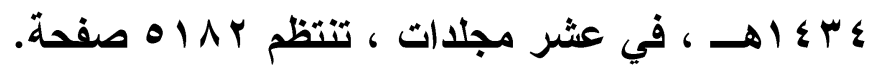

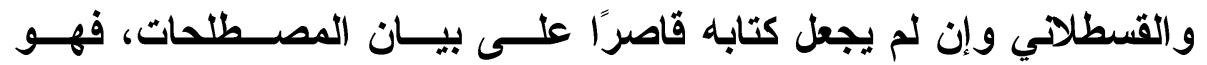

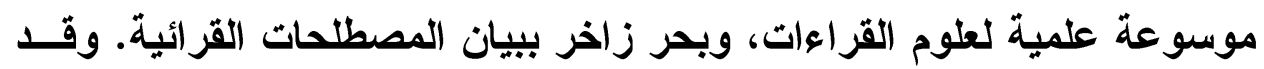

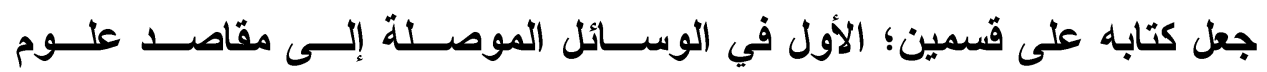

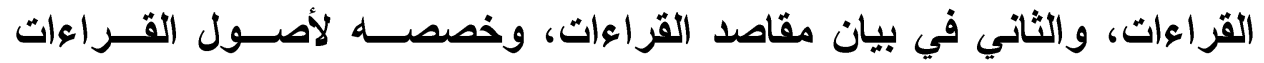
وفرشها، وما تثتمل عليه من مصطلحات قرائية.

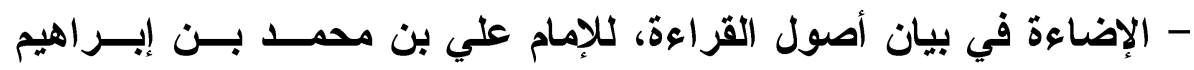

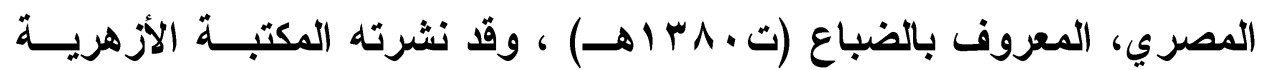

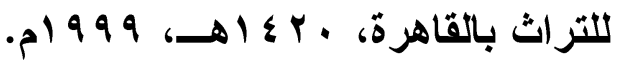

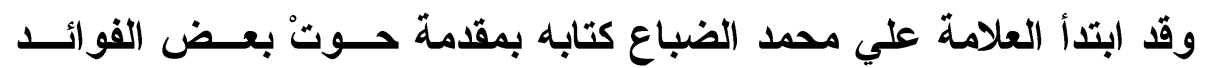

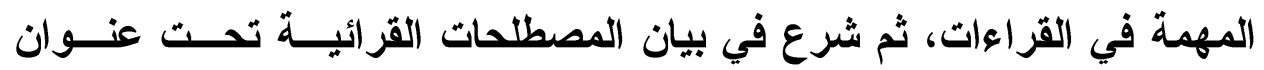
(المقصد في بيان أصول القراعات)، وضمّن ذلك القسم سبعة وثلاثين مصطلحًا.

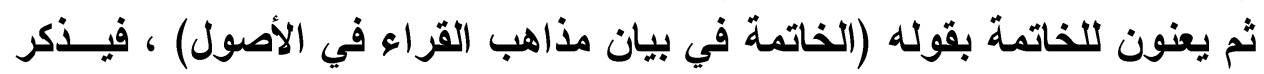


اصطلاحات الأحكام في علم القراءات وفن الأداء بين المدلول الشرعي والاستعمال الصناعي

فيها أصول كل قراعة من القراعات العثر المتواترة، مع إفراد أصول روايتـي قالون وورش عن نافع.

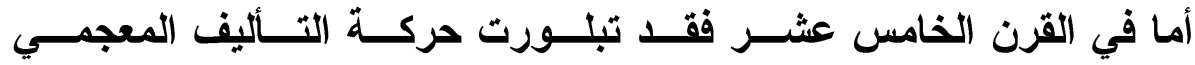
للمصطلحات القرائية؛ ذلك أن عددًا من الباحثين النابهين قد أفردوا المصـــاح

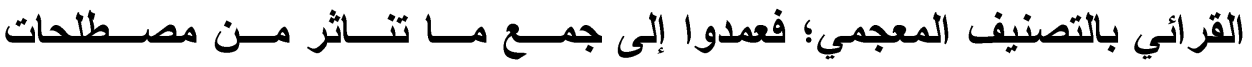

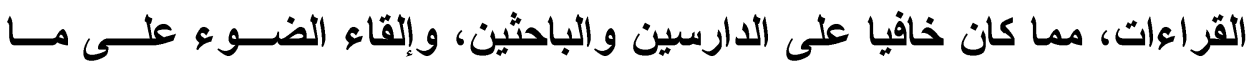
غمض من مفاهيمها، في قالب معجمي رصين، ومن نماذج هذه الجهات فود:

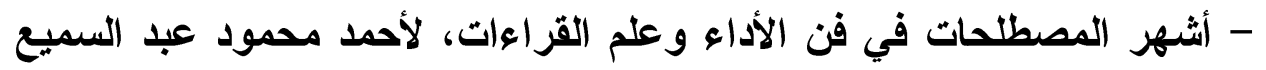

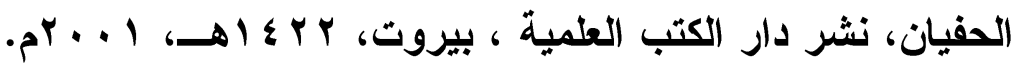

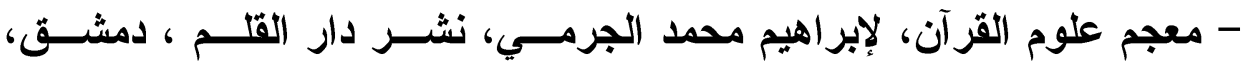

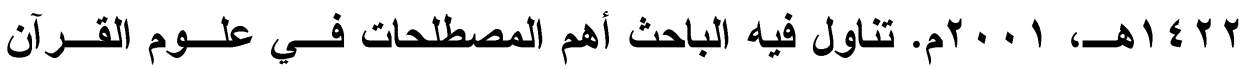

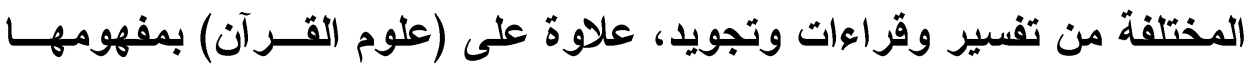
الاصطلاحي التركيبي الخاص.

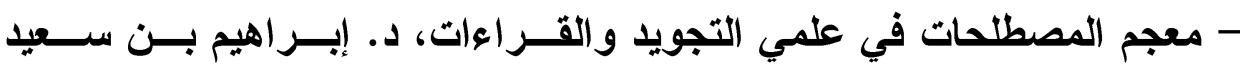

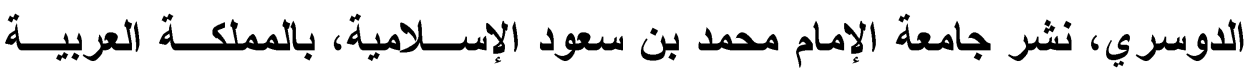

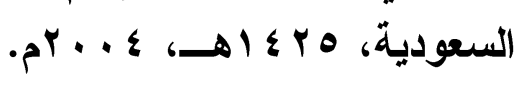

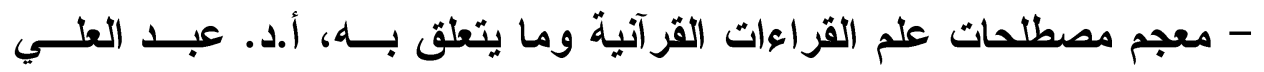

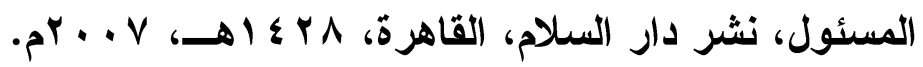

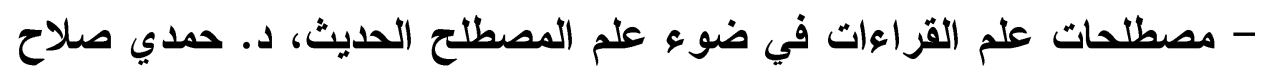

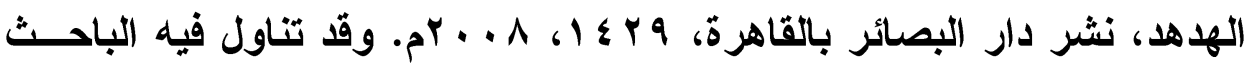
نشأة مصطلحات القراعات القرآنية وتطورها عبر القرون، ثم أردف ذلثك بمعجم

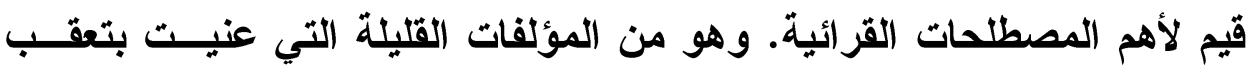
الاستعمال التاريخي للمصطلحات القرائية من بين ما ألف في المصطلح القرائي في عصرنا الحديث. - المعجم التجويدي لأثهر ألفاظ علم التجويد، د. عمر خليفة الثايجي، نشــر

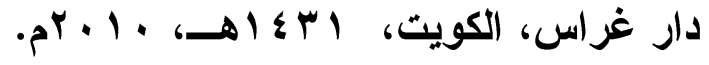


- معجم مصطلحات علوم القرآن، محمـــ بـن عبــــ الــرحمن الثـــايع، دار

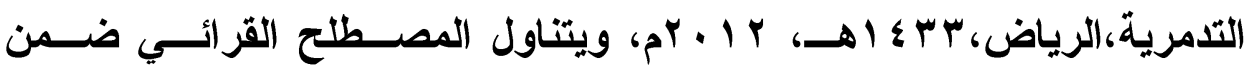
مصطلحات علوم القرآن المختلفة. وهذه المؤلفات المباركة التي جادت بها تلك القرائح الزاكية قد قطعت شوطا

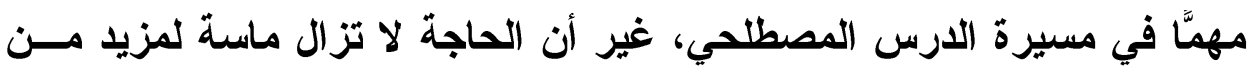
البيان والتقريب والتهذيب؛ ذلك أن هذه المؤلفات، ليست وافية تمام الوفاء بما

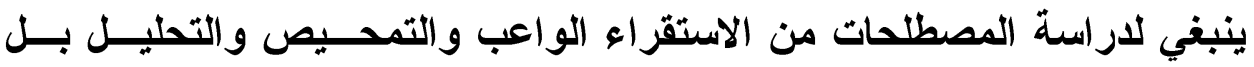

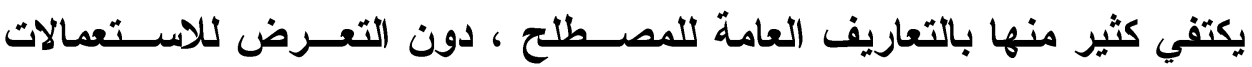

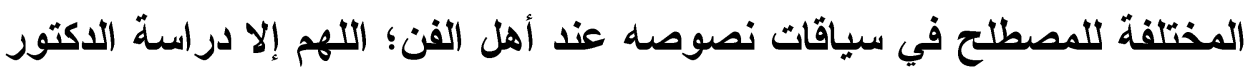
حمدي الهرهد. علاوة على فوت بعض المصطلحات القرائية في كثير من هذه المؤلفــات،

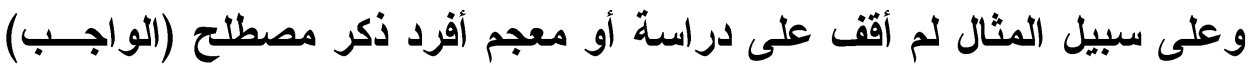

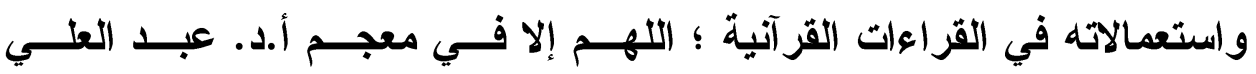

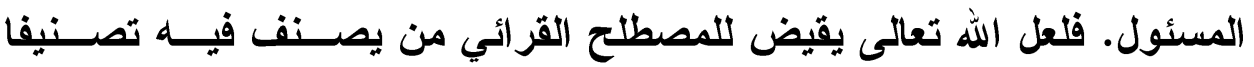

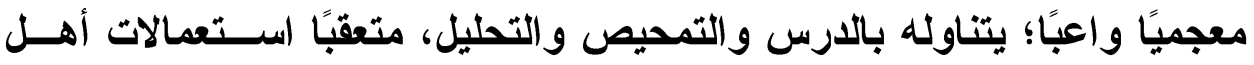

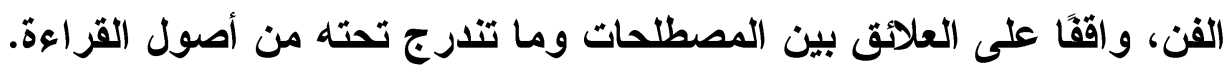
***

\section{المبرهذ النانيى}

دالات اصطلاج (الواجب الثر عي) وإطلاقاته في علم القراءات وفن الأداء المطالب الأول : الواهب لغة الغةً:

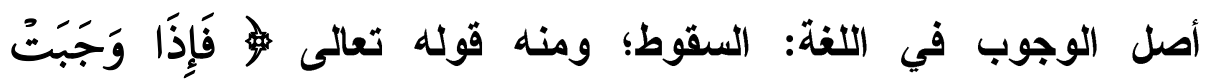

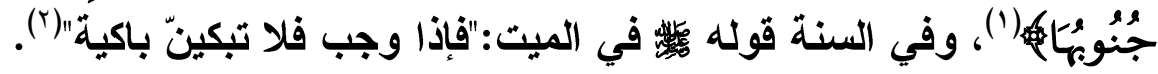

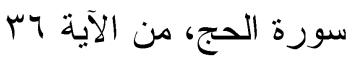

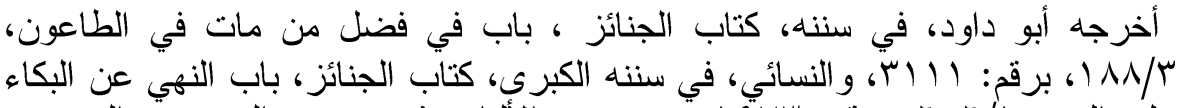

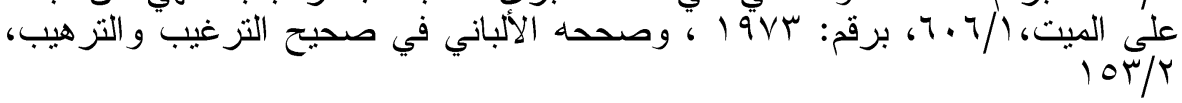


اصطلاحات الأحكام في علم القراءات وفن الأداء بين المدلول الشرعي والاستعمال الصناعي

ولما كان الساقط يلزم مكانه سُمي اللازم الأي لاخلاص منه واجبًا؛ قال ابن

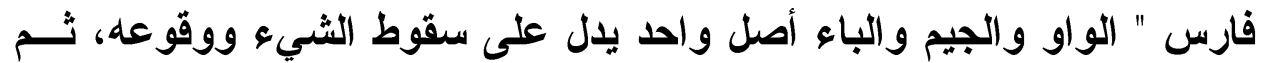
يتفرع"(')، ووجب الثيء يجب وجوبًا أي لزم وثبث، وأوجبه الله: استحقه (؟).

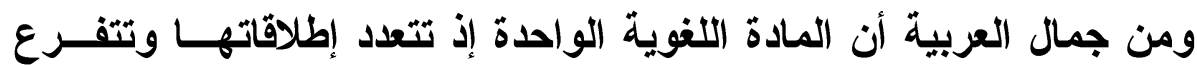

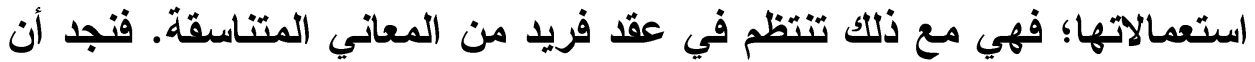

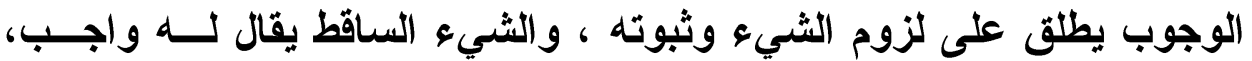

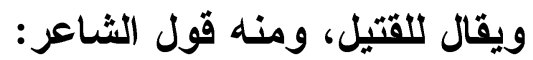

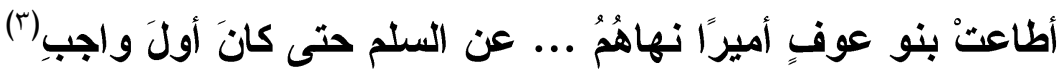

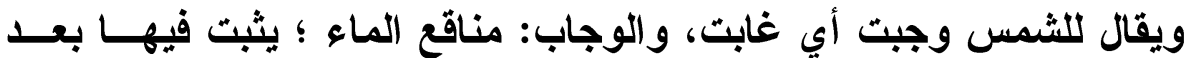
السيل ويلزم مكانه، والوجبة: أكلة واحدة في اليوم والليلة إلى مثلثها في الغـــــ

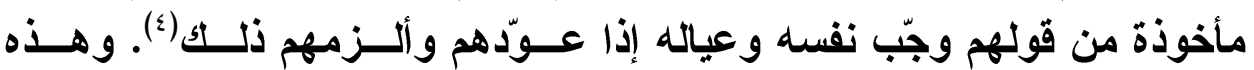

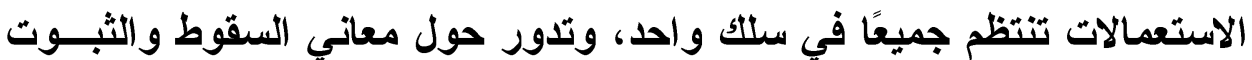
واللزوم.

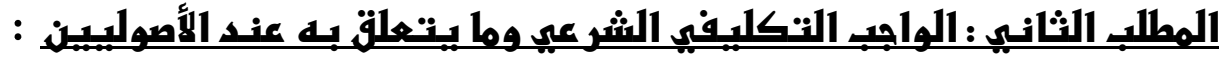

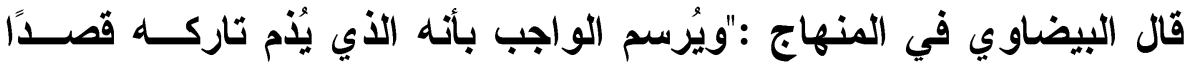

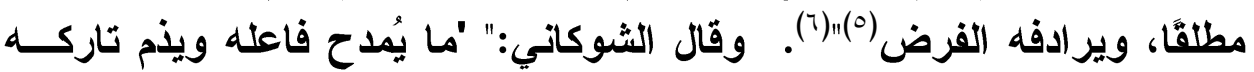
على بعض الوجوه "(V)

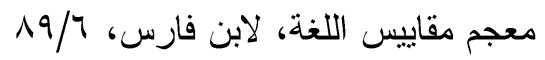

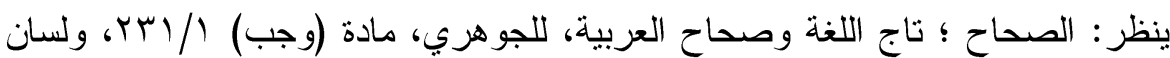

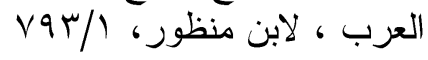

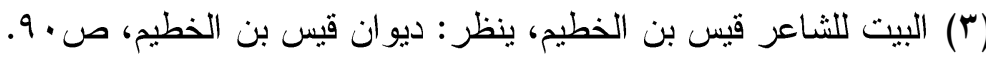

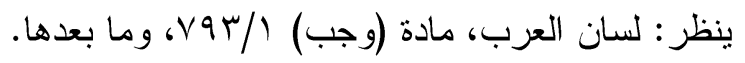

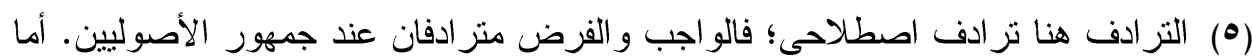

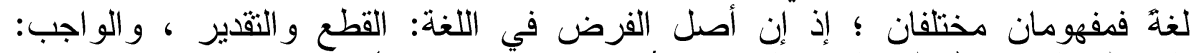

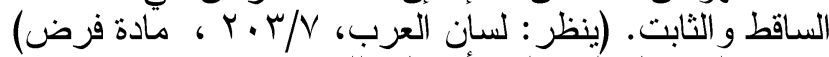

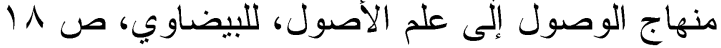

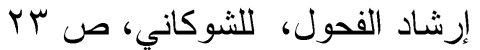




\section{بين الؤواجب والفرض:}

يفرق الحنفية بين الواجب والفرض كما يتبين من نسبة الإمام البيضــاوي

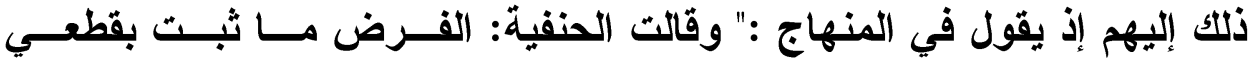
و الواجب بظني"(') قال محقق تيسير الوصول شرح منهاج الأصول، في بيان

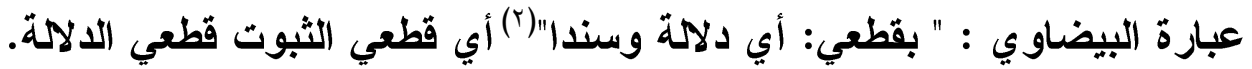

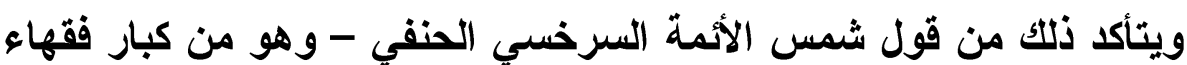

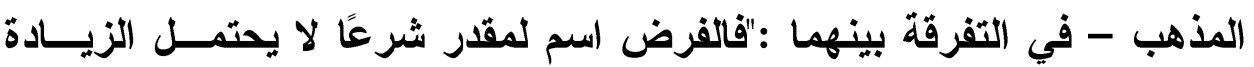
و النقصان، ومقطوع به... فأما الواجب فهو ما يكون لازم الأداء شرعًا، ولازم

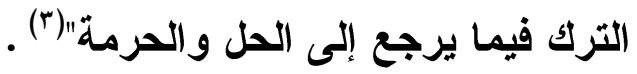

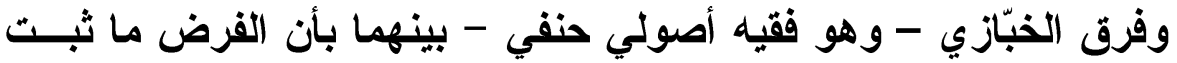

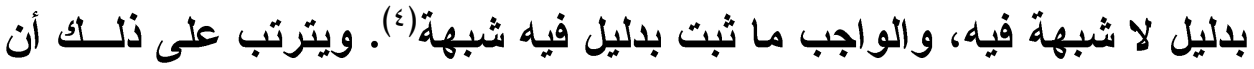

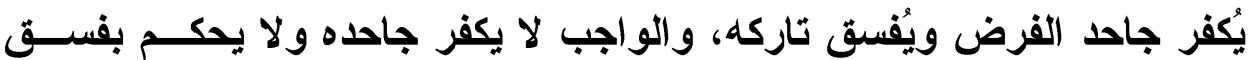

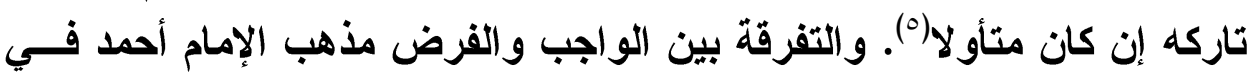

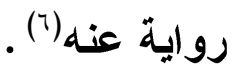

أما جمهور الأصوليين فلا يفرقون بين الواجب والفرض، وهو ما يتبين من

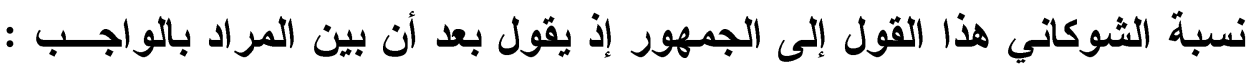

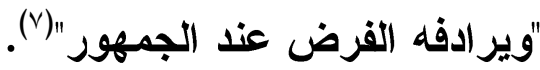
غير أن بعض الأصوليين ذهب إلى أن الخلاف لفظي، وأن ذلك مرده إلــى

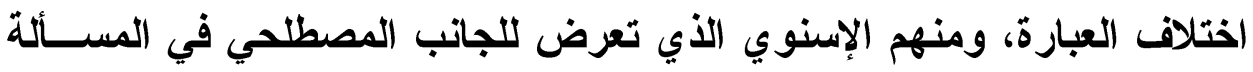

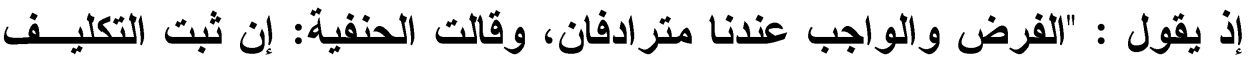

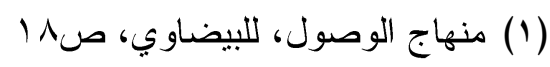
(ץ) تيسير الوصول إلى منهاج الأصول، لابن إمام الكاملية، تحقيق: د.عبدالفتاح أحمد قطب، r 1 r

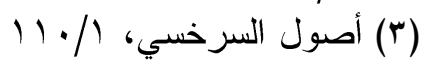

(ع) و المر اد بالثبهة هنا ما كان ظني الدلالة كالآية المؤولة، أو ظني الثبوت كخبر الآحاد.

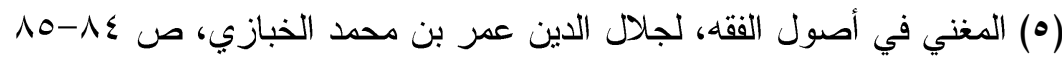

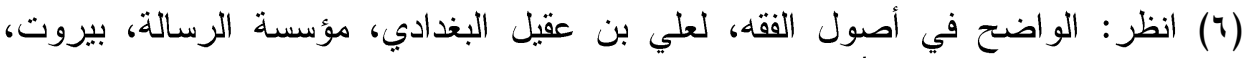

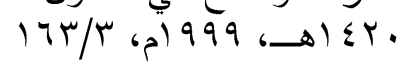

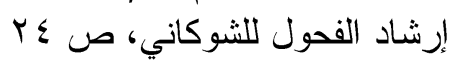


اصطلاحات الأحكام في علم القراءات وفن الأداء بين المدلول الشرعي والاستعمال الصناعي

بلايل قطعي مثل الكتاب والسنة المتواترة فهو الفرض كالصلوات الخمس، وإن

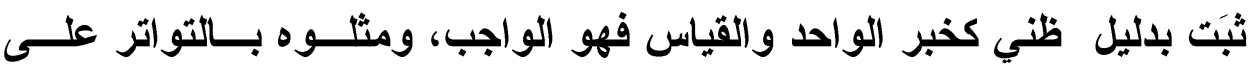

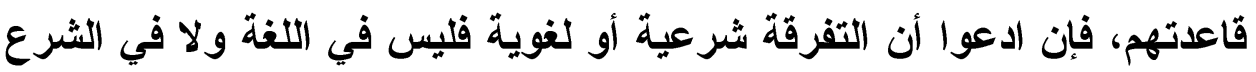

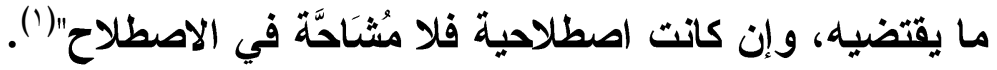

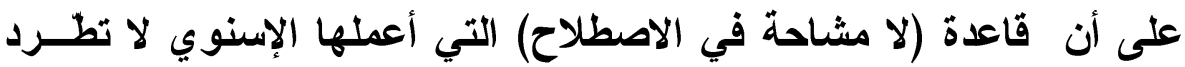

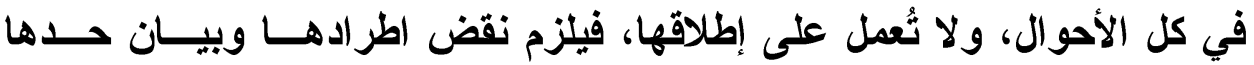

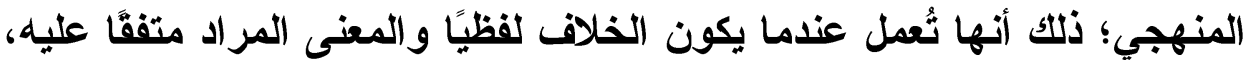

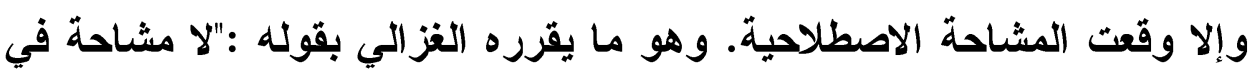

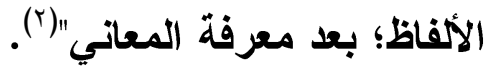

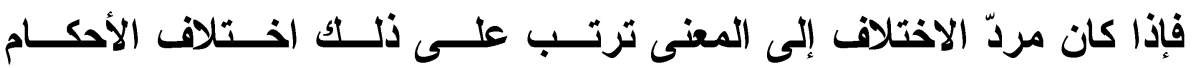
و المفاهيم ووقعت المشاحة، ومصداق ذلك أن الحنفية قد رتبوا على التى التفرقة بين

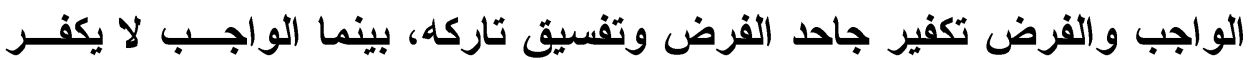

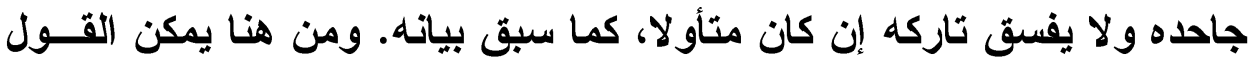

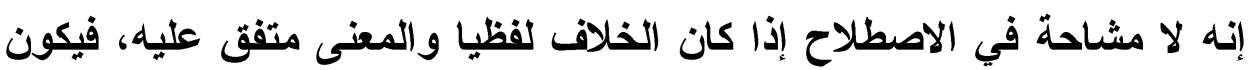
الخلاف في اللفظ لا المعنى، وفي العبارة لا الاعتبار، وإلا وقعت المشاحة فــي الاهي الاصطلاح.

و إذا كان مجال البحث لا يتسع لتحقيق القول في أدلة كلا الفريقين وأوجـهـ

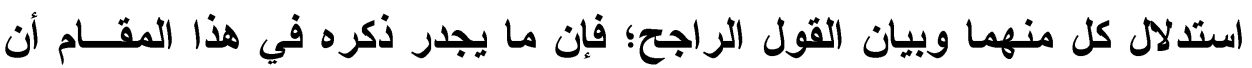

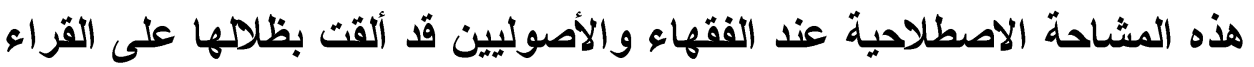

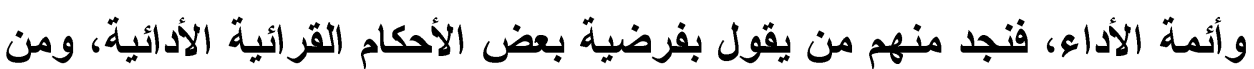

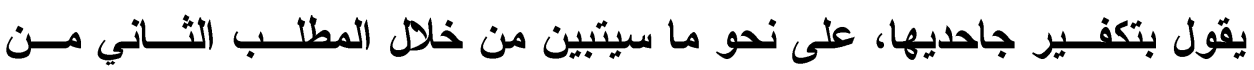

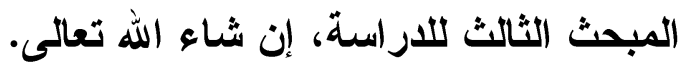




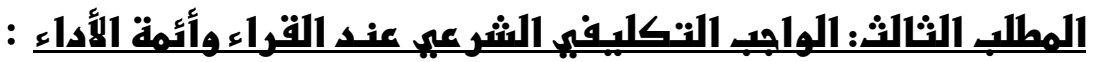
يطلق اصطلاح (الواجب الثرعي) عند المقرئين وائمة التجويد ، ويراد به

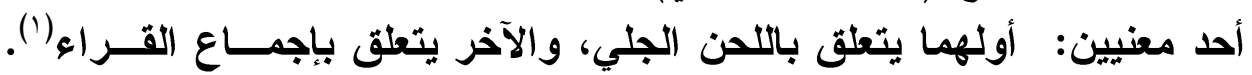
وفيما يأتي بيان كل منهما.

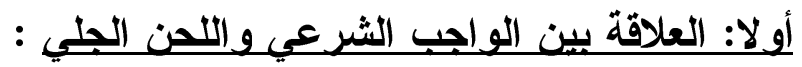

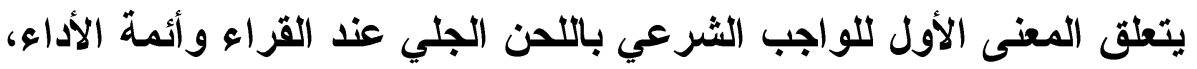

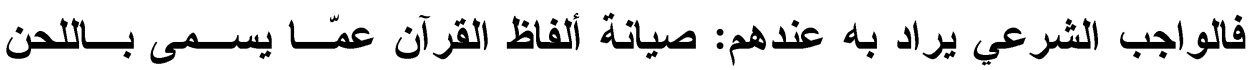

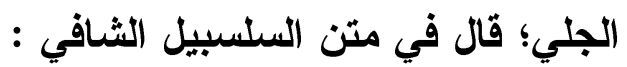

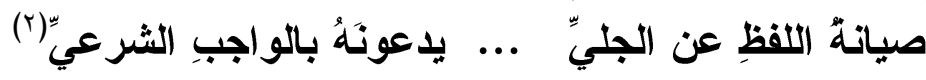

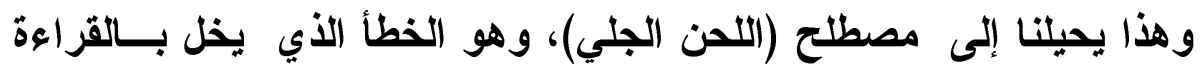

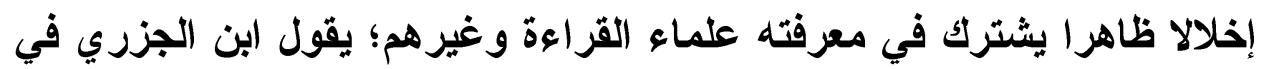

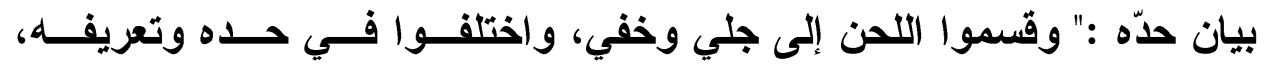
والصحيح أن اللحن فيهما خلل يطرأ على الألفاظ فيخل وإلا أن الجلي يخلّ إخلالاً

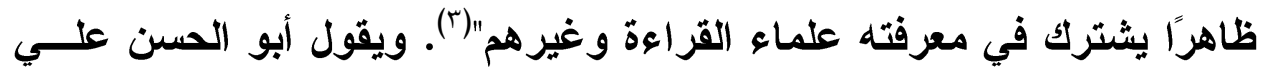

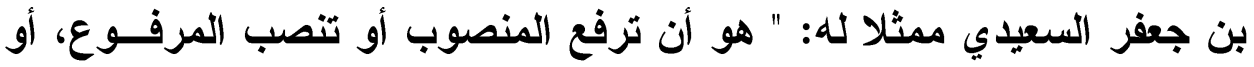

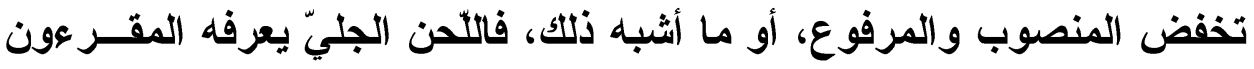

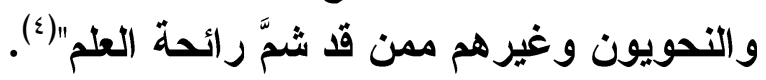

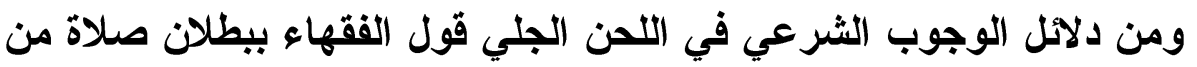

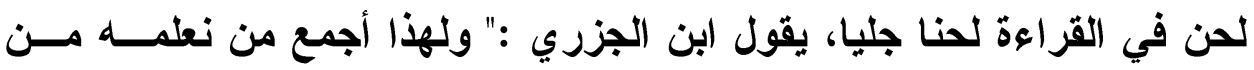

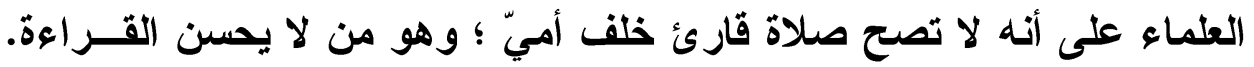

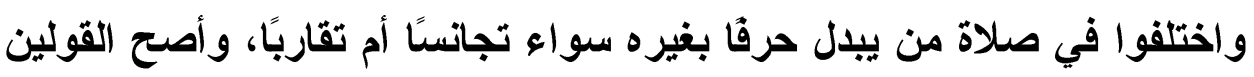

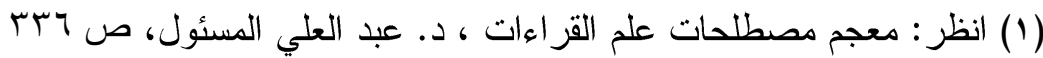

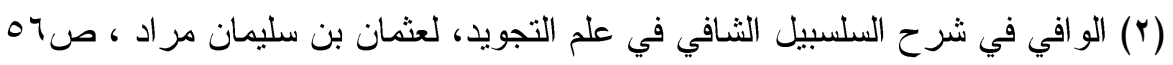

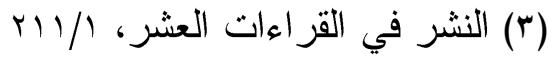

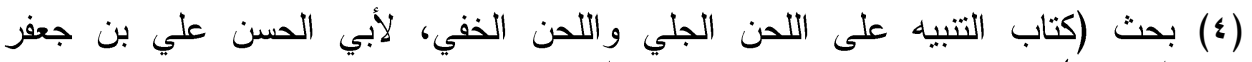

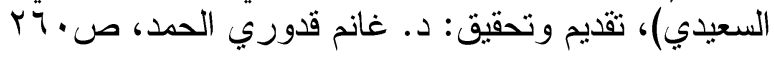


اصطلاحات الأحكام في علم القراءات وفن الأداء بين المدلول الشرعي والاستعمال الصناعي

عدم الصحة"('). ولا يخفى ما للإمام ابن الجزري من رسوخ فقهي علاوة على إمامته القر ائية(؟) وفرق الفقهاء في ذلكك بين الفاتحة وغيرها؛ إذ الفاتحة ركن في الصلاة، فلا

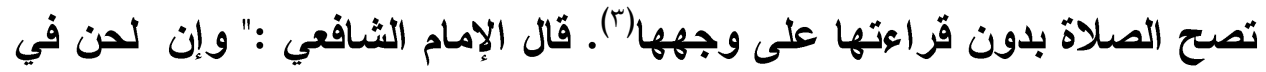

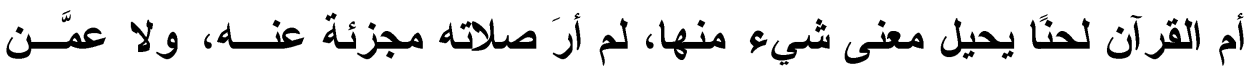

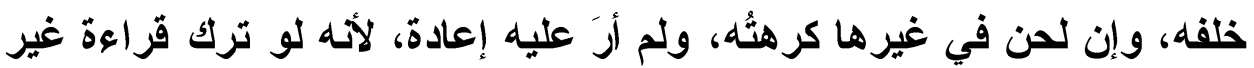

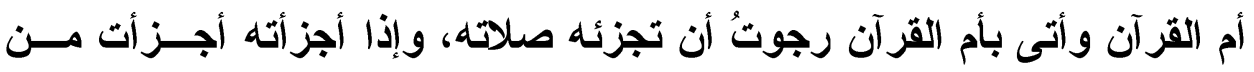

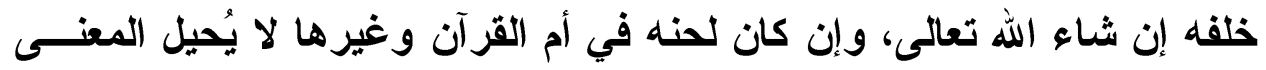

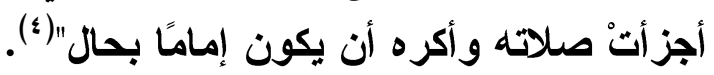

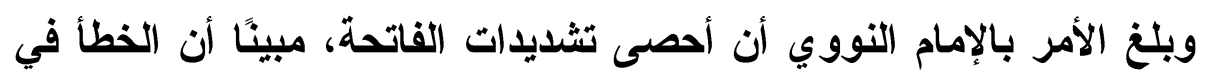

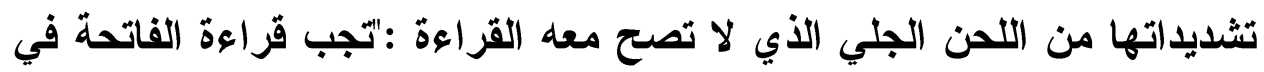

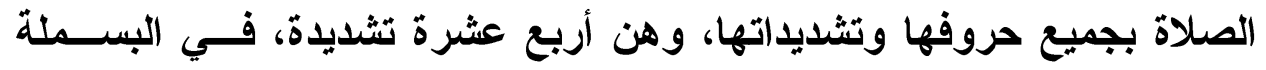

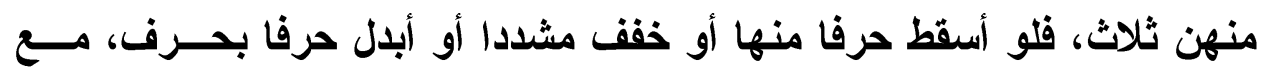

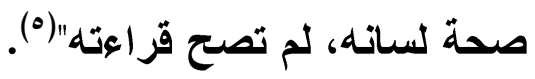
وقال الموفق ابن قدامة :" ومن ترك حرفا من حروف الفاتحة ؛ لعجزه عنهه،

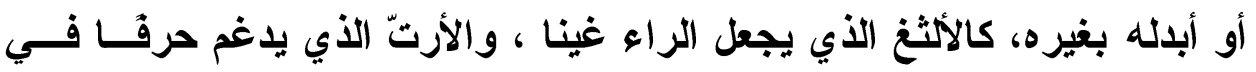

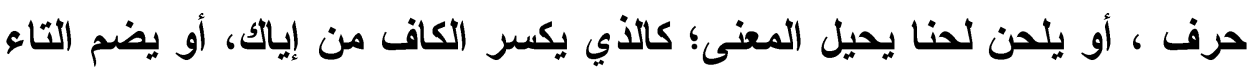

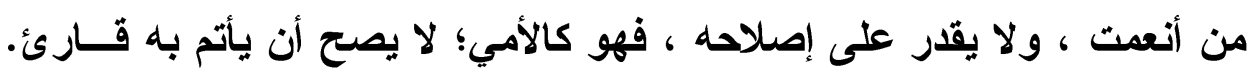

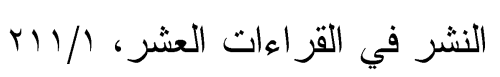

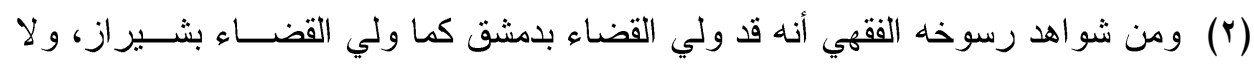

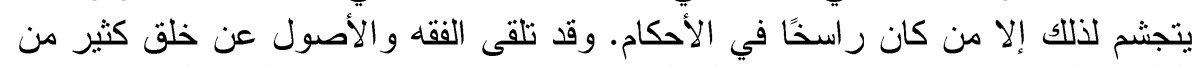

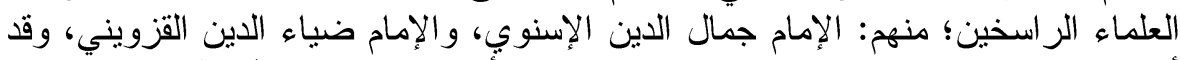

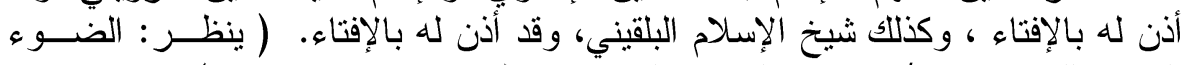

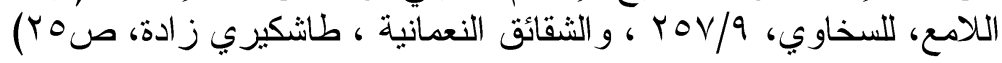

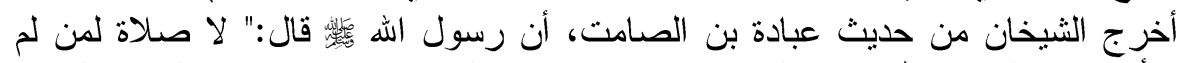

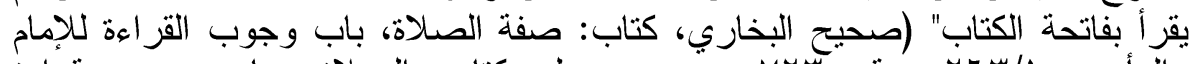

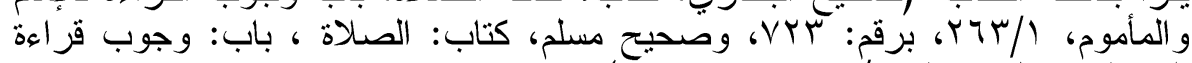

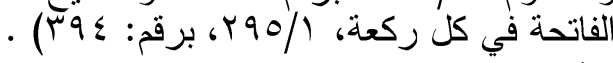

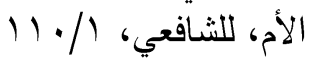

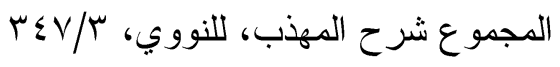


ويجوز لكل واحد منهم أن يؤم مثله ؛ لأههما أميان ، فجاز لأحـــهما الائثــام

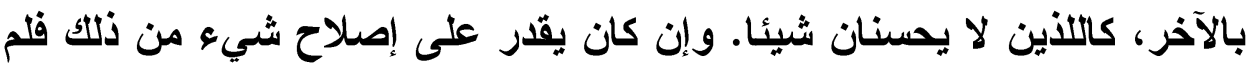

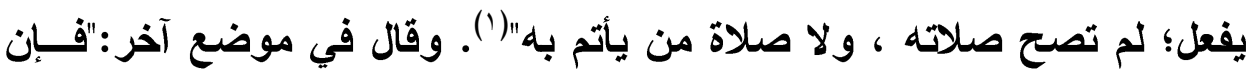

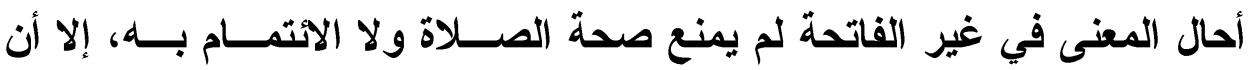

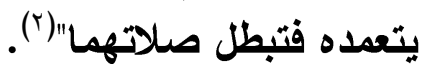

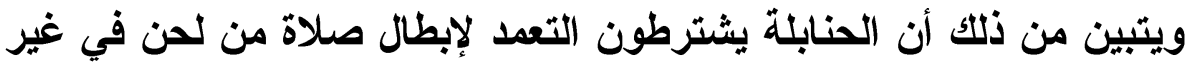

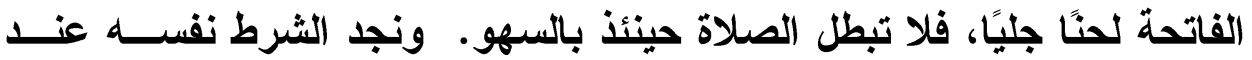

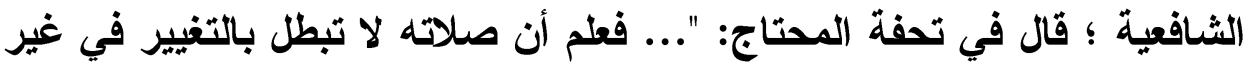

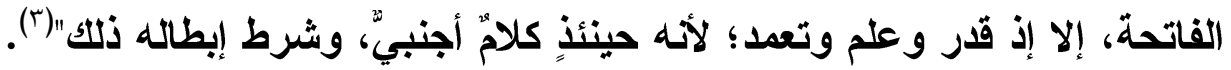

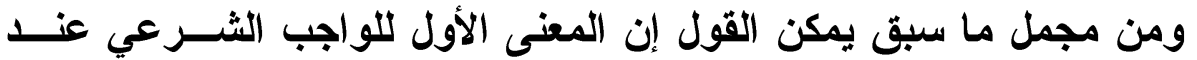

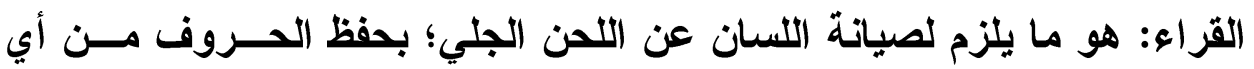

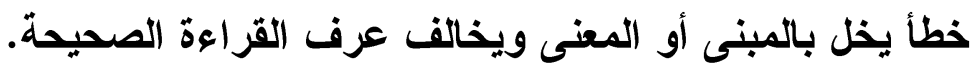

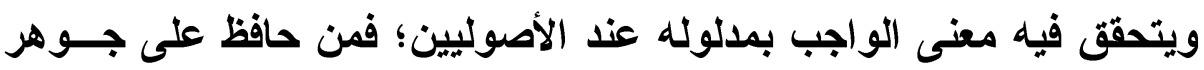

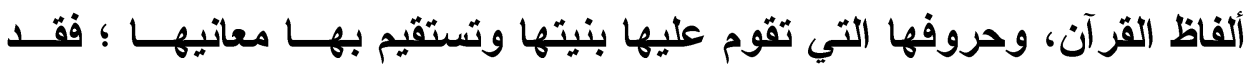

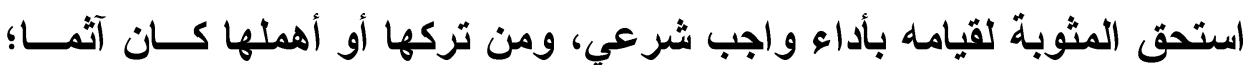
لتركه الواجب الثرعي.

\section{ثانبا: العلاقة بين الواجب الثرعي وإجماع القزاء :} والمعنى الثاني للواجب الشرعي: ما وقع عليه إجماع القراع، قال في متن السلسبيل الشافي:

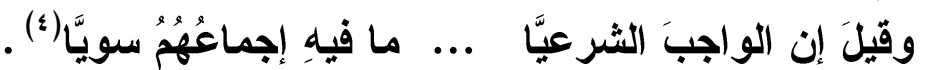

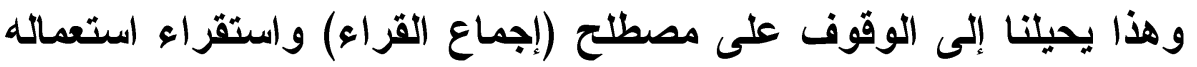

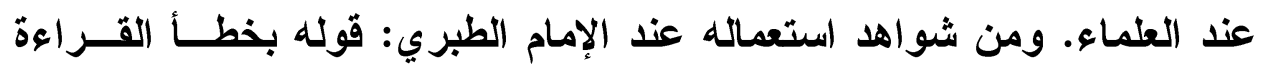
وشذوذها إذا خرجت عن إجماع القراء ، وله في التعبير عن إجمـاعهم صــيغ الطمين

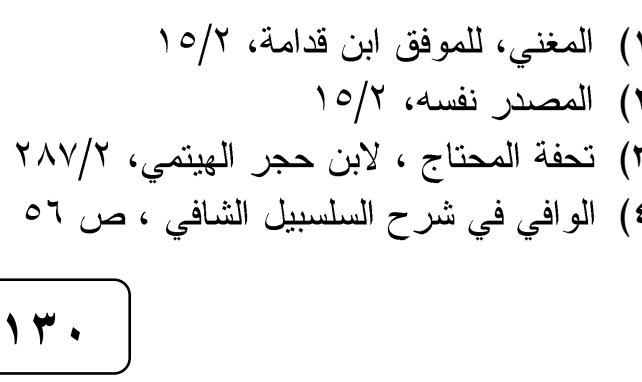

Ir. 


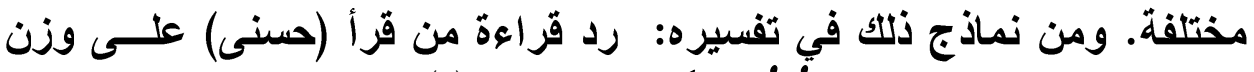

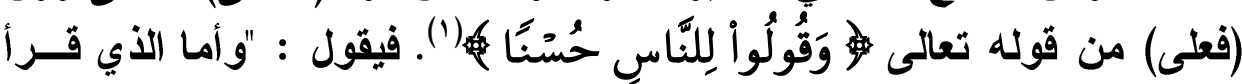

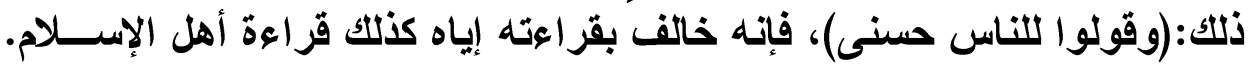

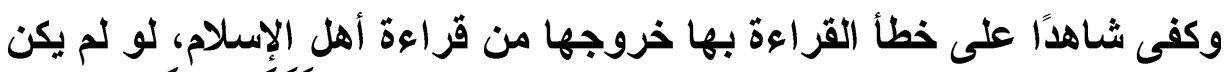

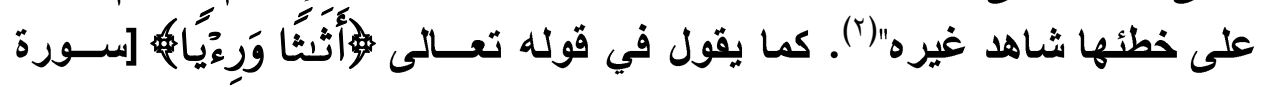

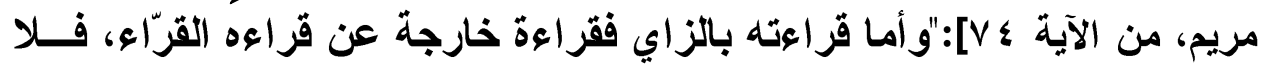

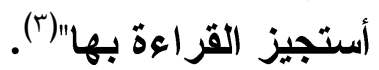

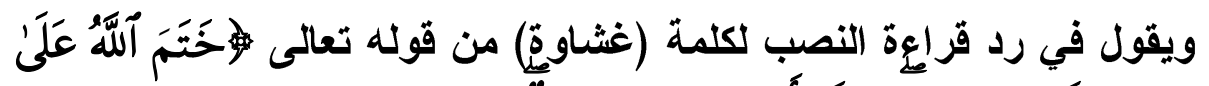

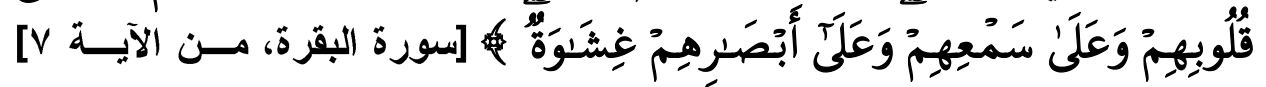

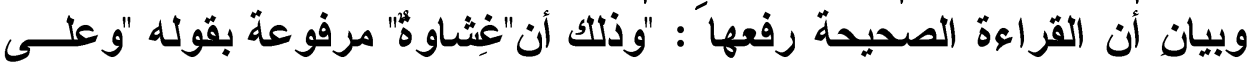

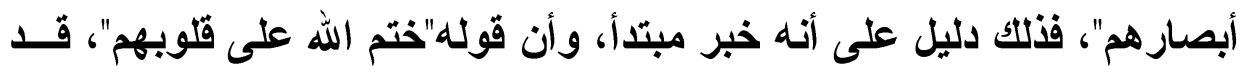

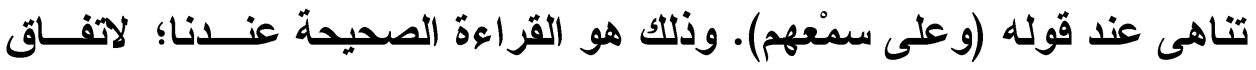

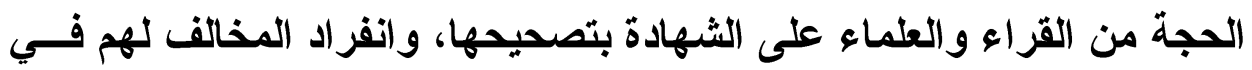

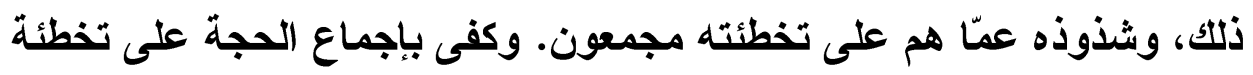

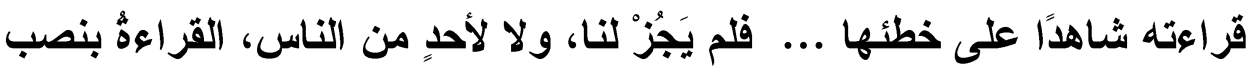

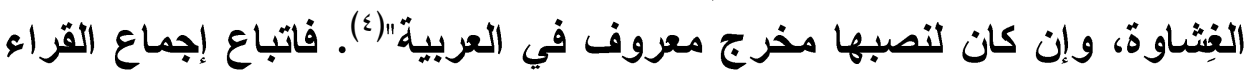

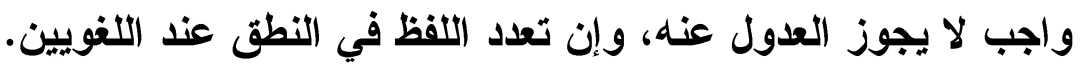

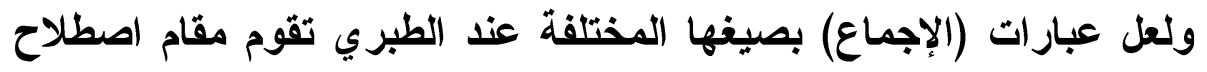

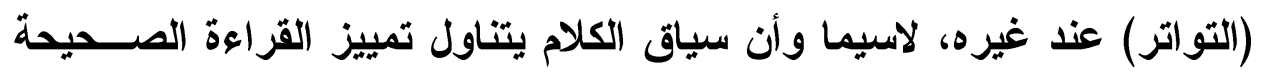

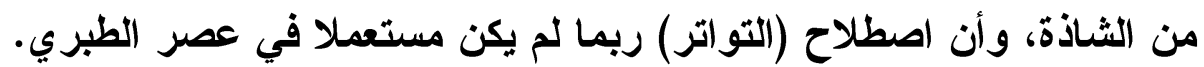

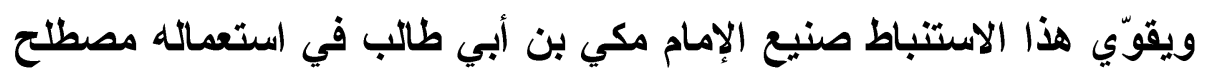

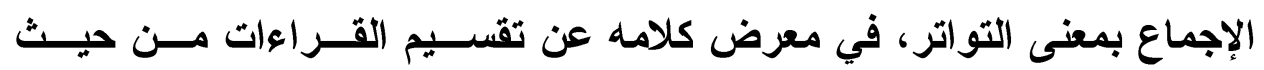

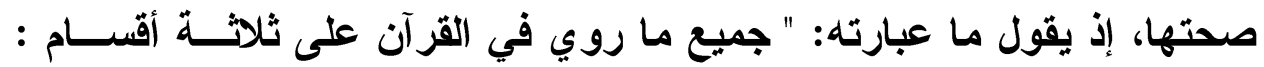

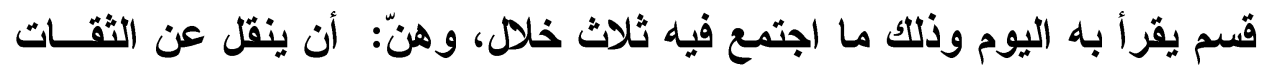

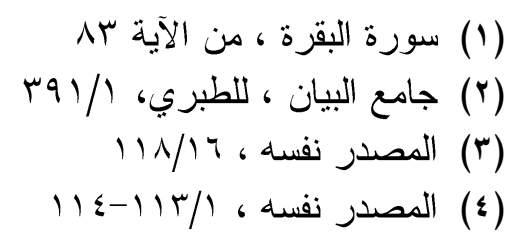




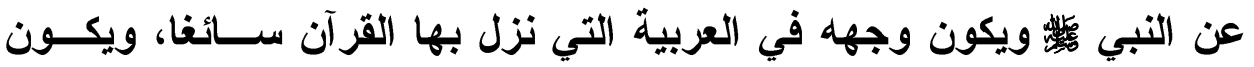

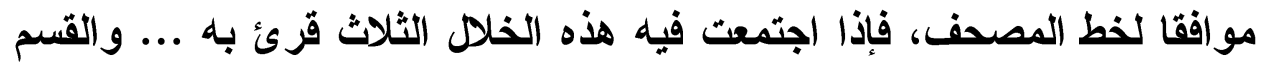

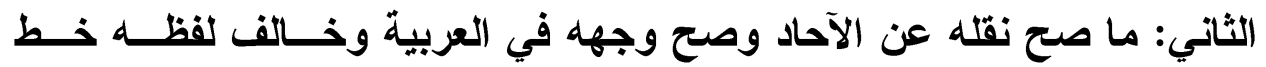

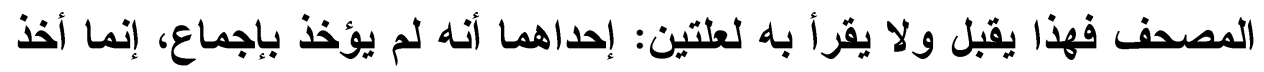

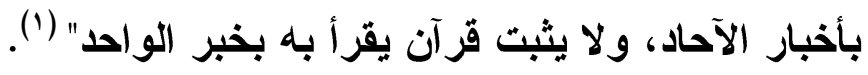

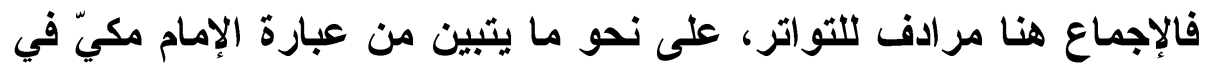

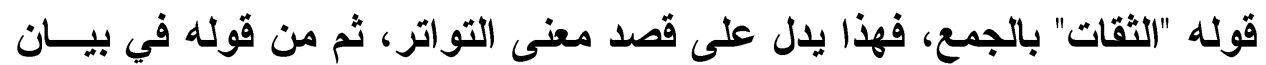

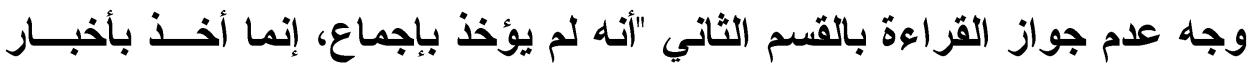
الآحاد".

كما يتبين أن اصطلاح (قبول القراعة) في قول مكيّ "فهذا يقبل ولا يقرأ به"

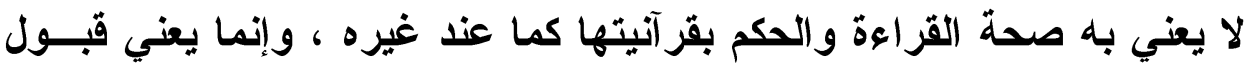

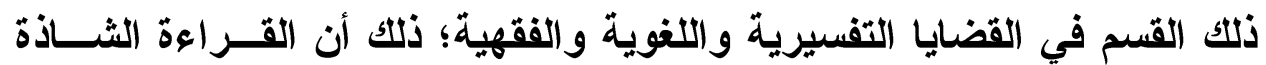

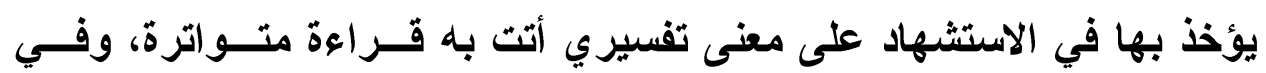
الاحتجاج لصحة قاعدة نحوية أو صرفية، كما يحتج بها بعض لفول الفقهاء لآرائهم.

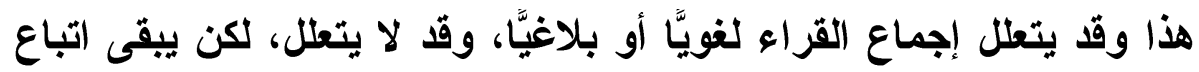

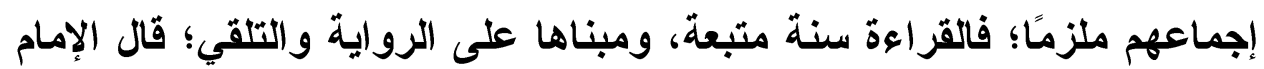

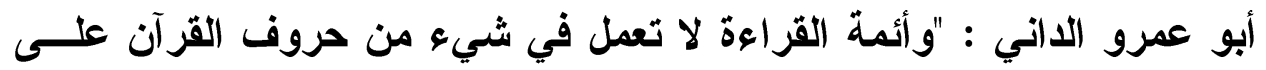

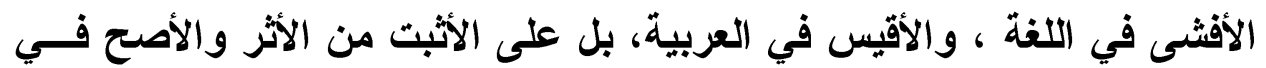

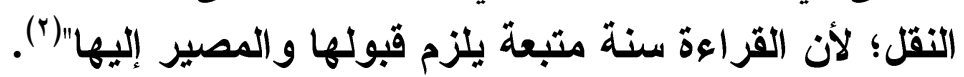

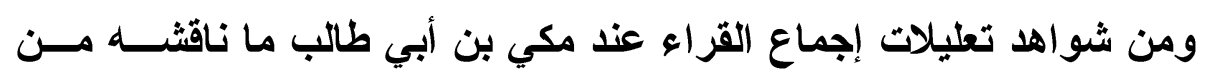

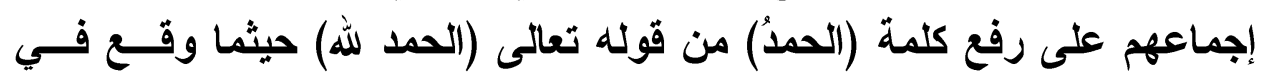

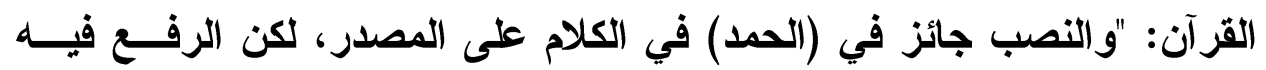

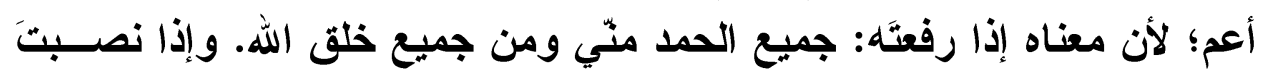

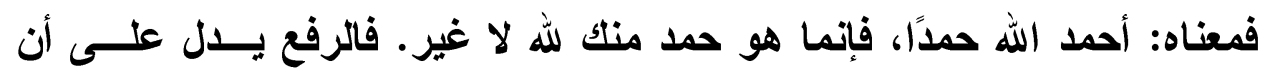

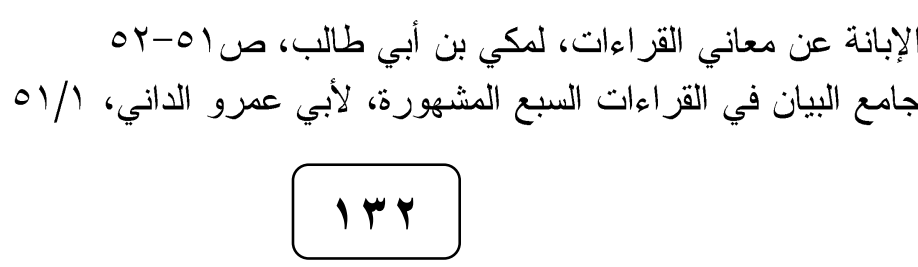




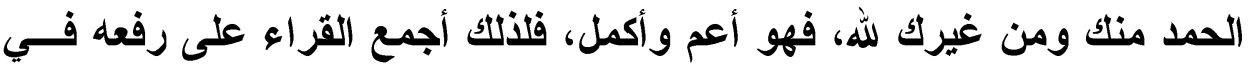
جميع ما وقع في القرآن من لفظ (الحمد لله)"(1).

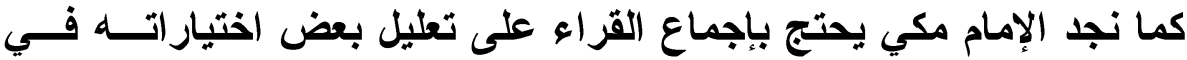

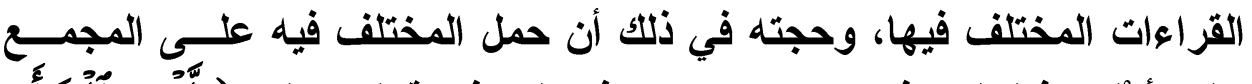

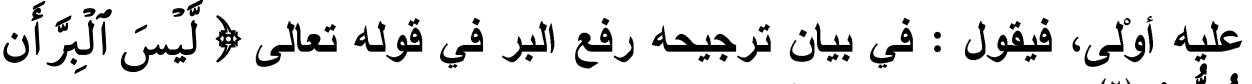

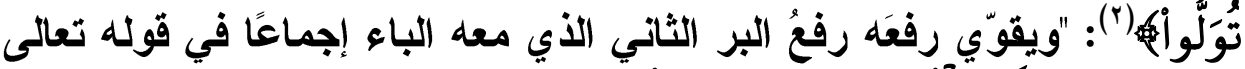

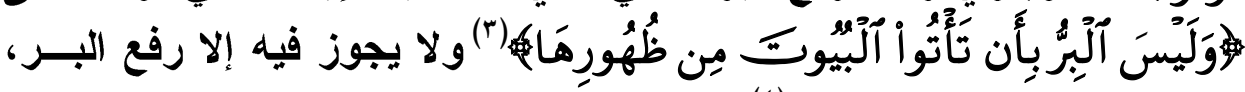

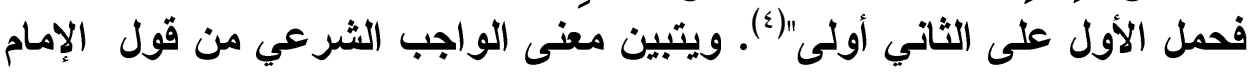

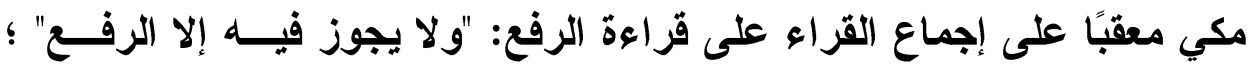

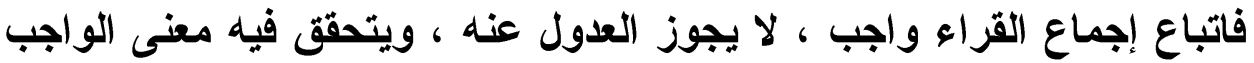
بمعناه الشرعي كما هو عند الأصوليين. ولفظ البر المقترن بـ (ليس) قد ورد في القرآن على حرفين: أحدهما فـي الهي

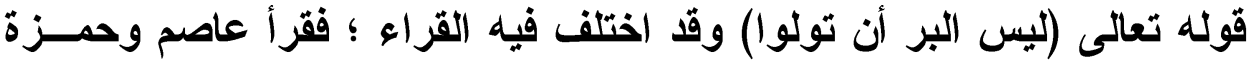

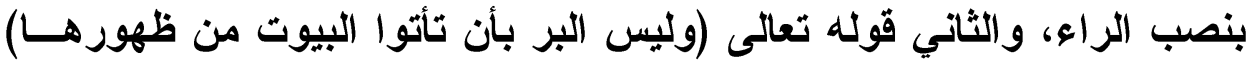

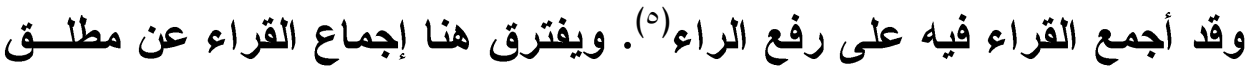

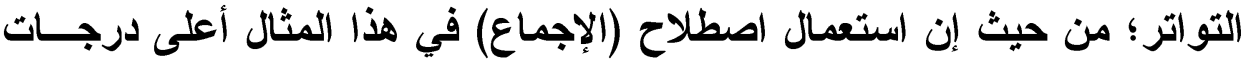

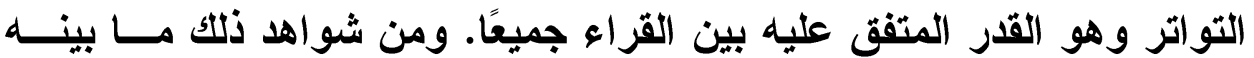

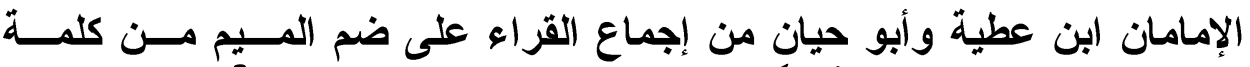

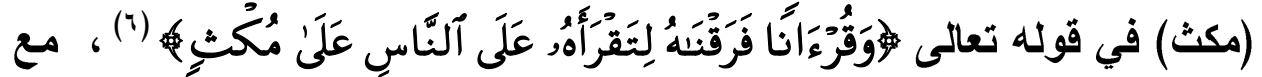

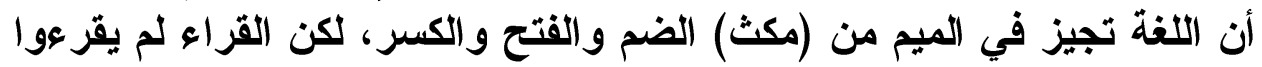

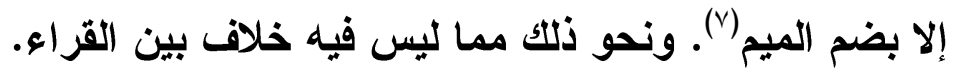

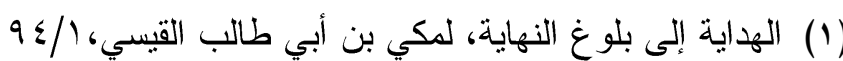

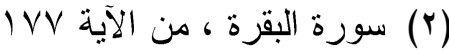

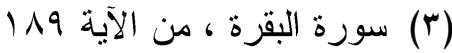

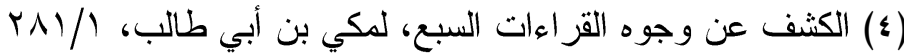

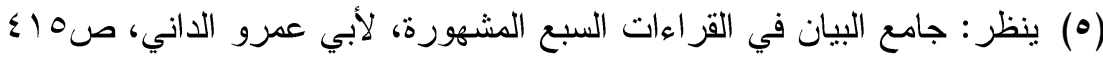

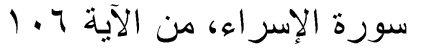

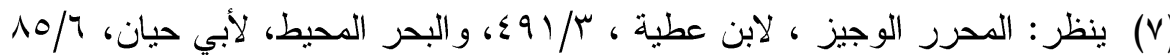




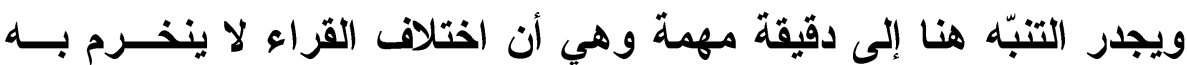

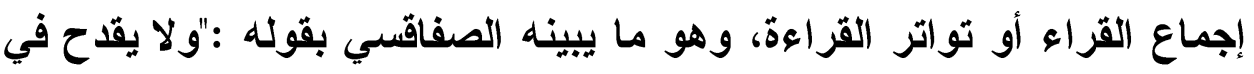
ثبوت التواتر اختلاف القراعة؛ فقد تتواتر القراعة عند قوم دون قوم. فكل مسن فئن

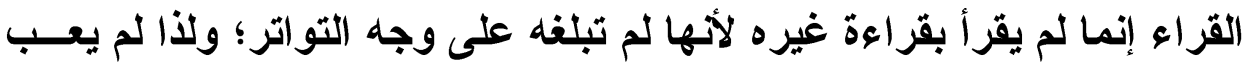

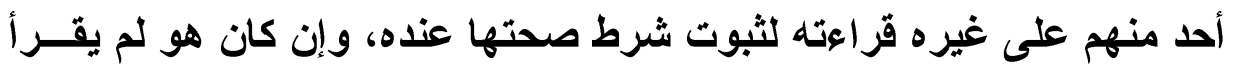

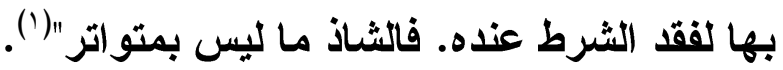

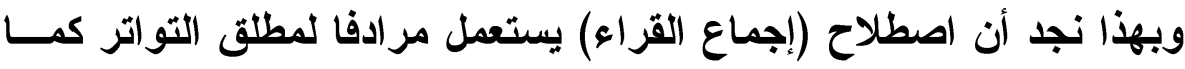

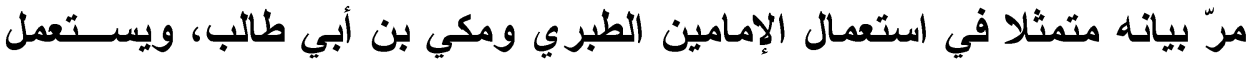

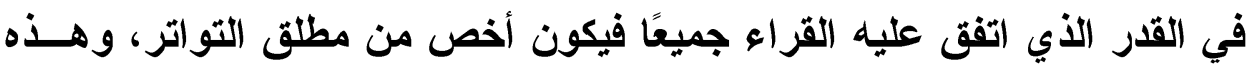

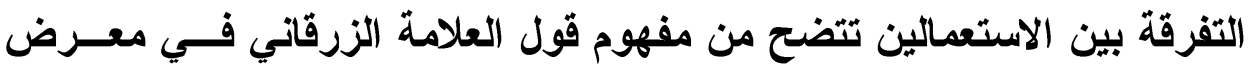

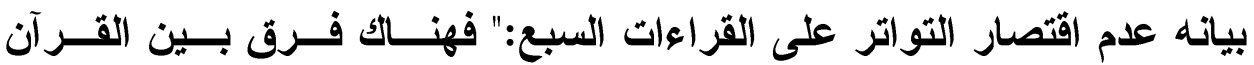

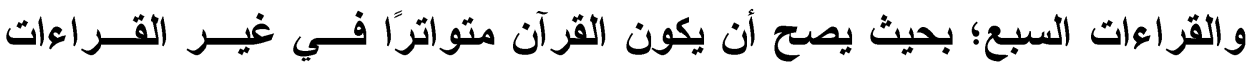
السبع، أو في القدر الأي اتفق عليه القراء جميعًا، أو في القدر الأي اتفق أتى عليه

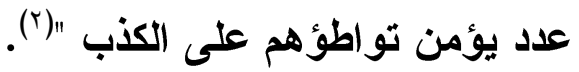

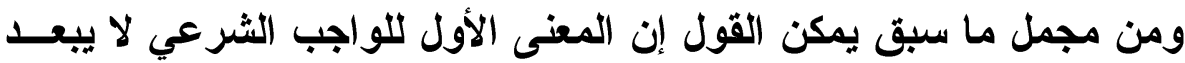

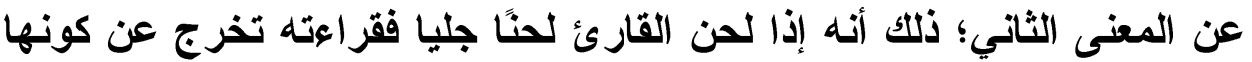

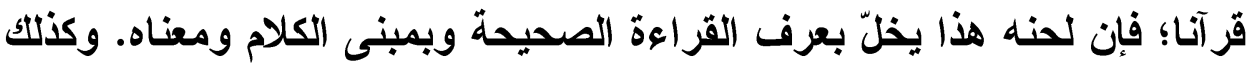

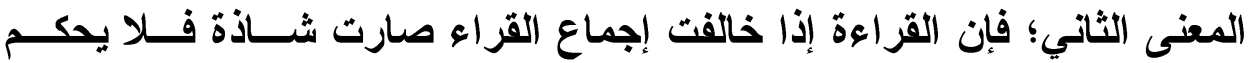

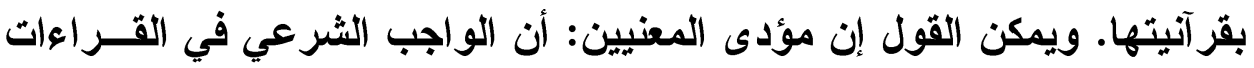
والأداء ما يتعلق بتمييز القرآن عن غيرهن آندون ***

(1) غيث النفع ، للصفاقسي ، صع الزئ (1)

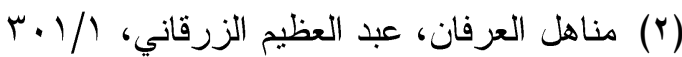




\section{اصطلاحات الأحكام في علم القراءات وفن الأداء بين المدلول الشرعي والاستعمال الصناعي}

\section{المبرمث الفنالث}

دلالات اصطلام (الواجب المنـاعي) وإطلاقاته في علم القراءات وفنز الأداء

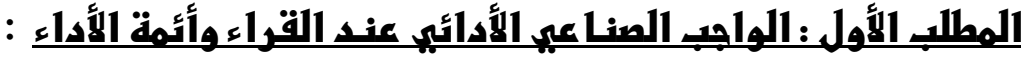

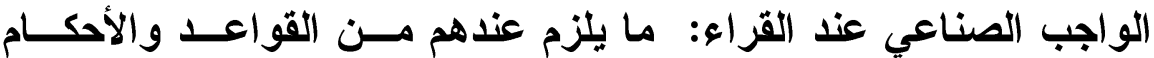

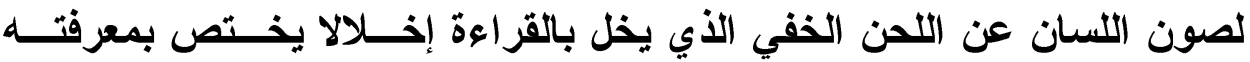

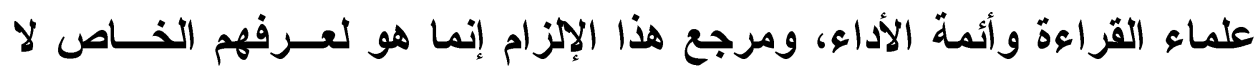

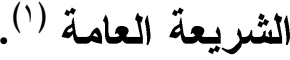

وعبر عن ذلك صاحب متن السلسبيل بقوله:

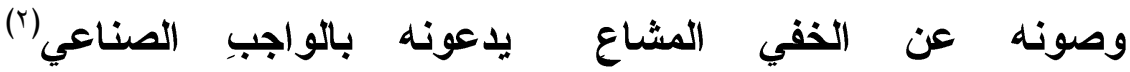
واللحن الخفي لا يخل بالمعنى ولا الإعراب، غير أنه يخل بقواعد فن الأداء

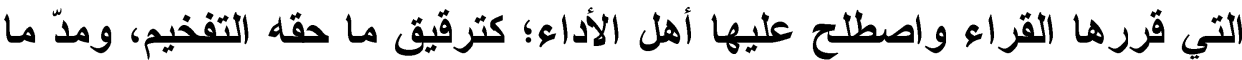

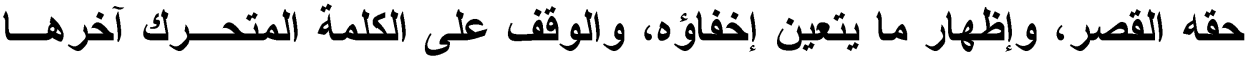

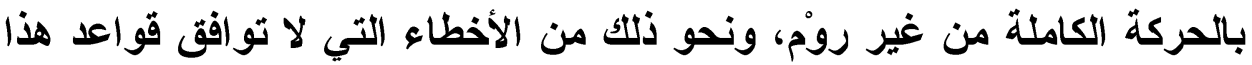

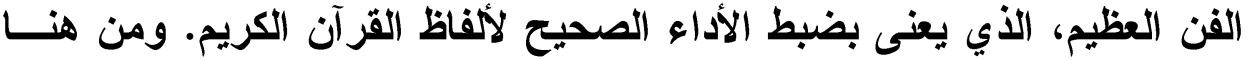

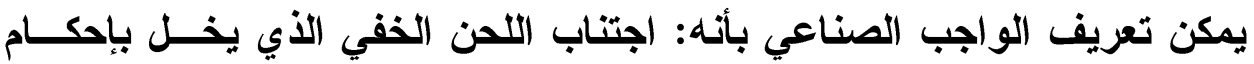

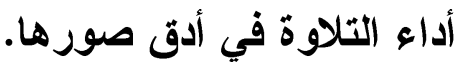

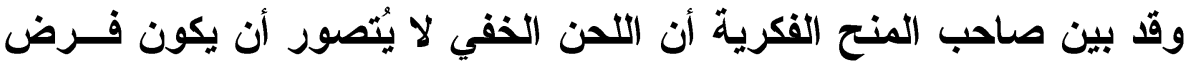

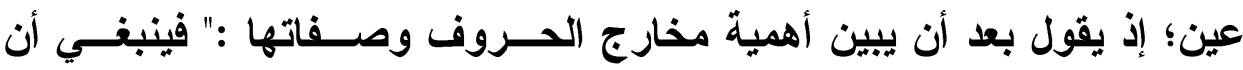
ير اعي جميع قو اعدهم وجوبًا فيما يتغير به المبنى ويفسد المعنى ، واســــــابًا

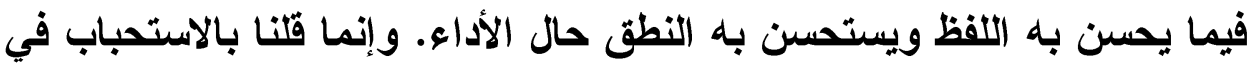

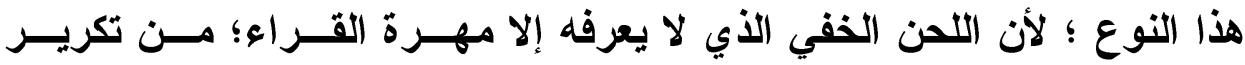

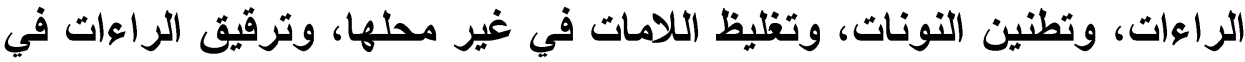

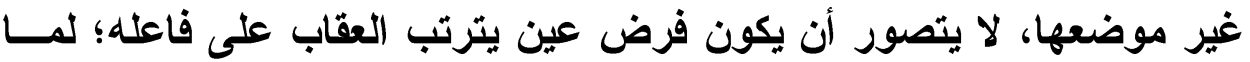

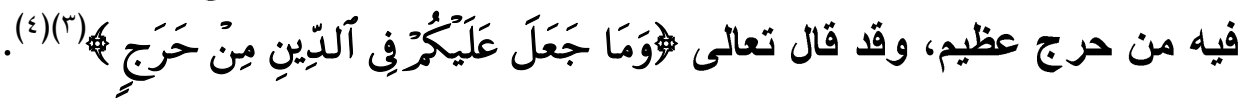

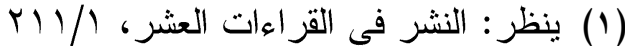

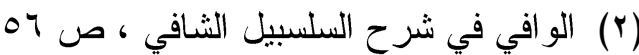

$$
\begin{aligned}
& \text { V^ سورة الحج، من الآئية } \\
& \text { ( ) المنح الفكرية في شرح المقدمة الجزرية، ملا علي القاري، ص لالح } 117
\end{aligned}
$$


وللواجب الصناعي استعمالات مختلفة، تتمثل فيما يأتي:

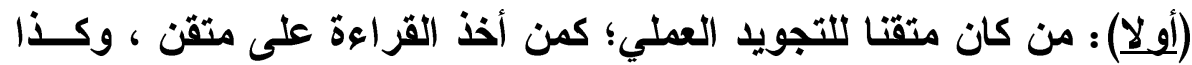

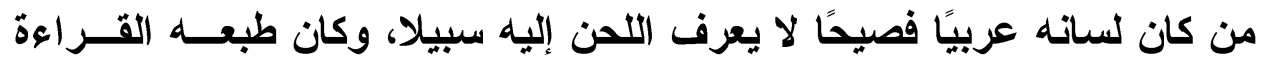

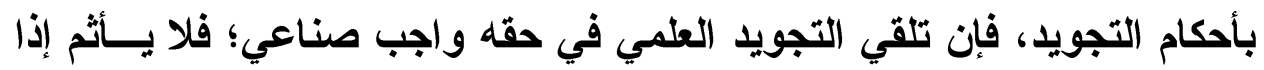

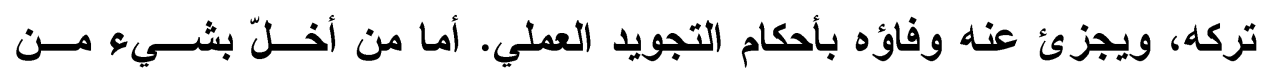

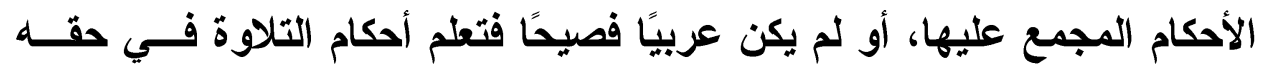
واجب شرعي؛ قال أبو حامد الغزالي :" والذي يكثر اللحن في القرآن إن إن كــان

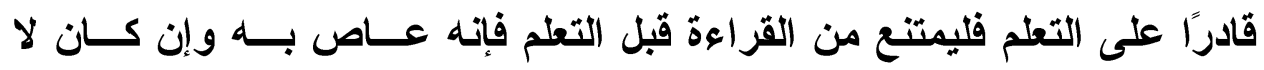

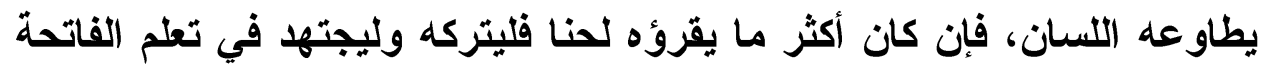

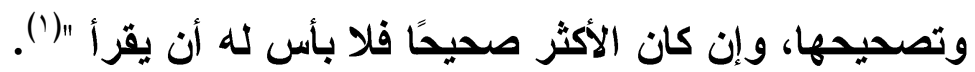

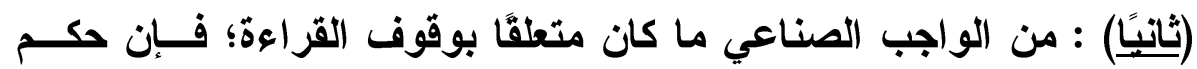
القراء بوجوب الوقف على بعض المواضع ليس مراده ما هو مقرر في الأحكام

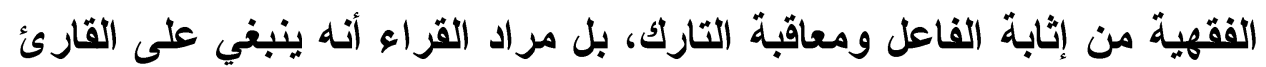

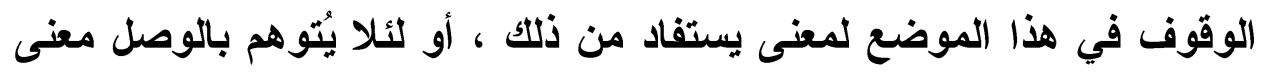

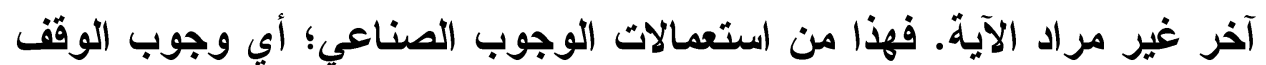
صناعة.

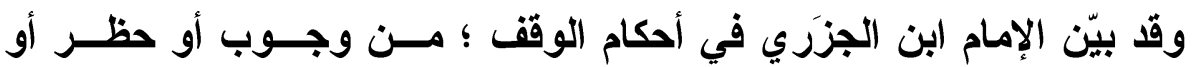

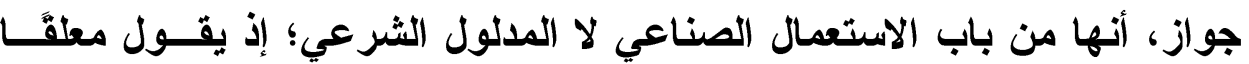

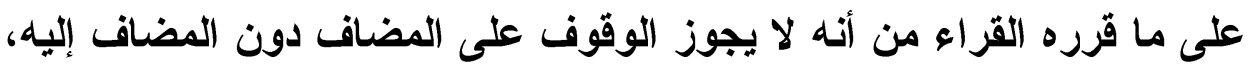

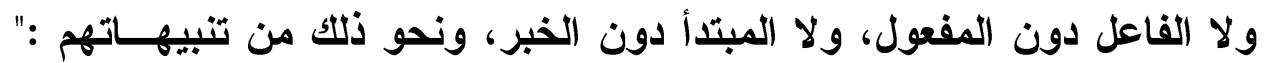

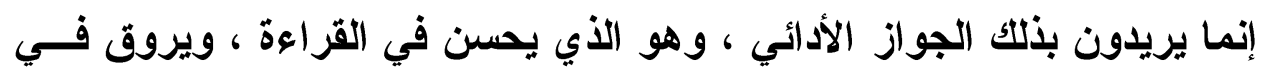

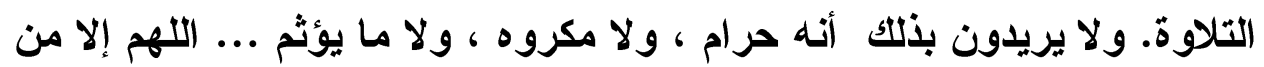

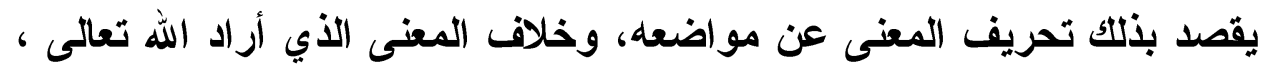
فإنه - والعياذ بالله - يحرم عليه ذلتك، ويجب ردعه بحسبه على ما تقتضهـيه وخليه الشريعة المطهزة، والله تعالى أعلم" (r).

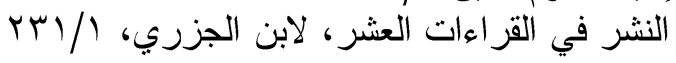


اصطلاحات الأحكام في علم القراءات وفن الأداء بين المدلول الشرعي والاستعمال الصناعي

ويقول عن الوقف الواجب عند القراء :" من الأوقاف ما لو وصــل طرفـــاه

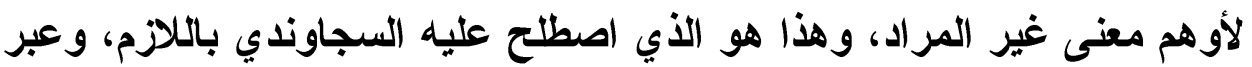

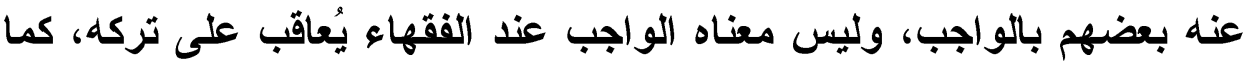
توهمه بعض الناس" (1) (ثالثثا) : من استعمالات الواجب الصناعي ما كان من باب اختلاف القـــراء

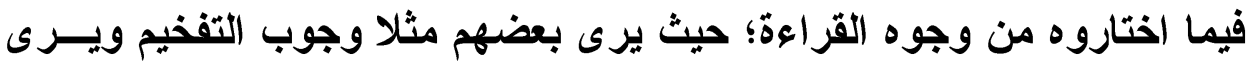

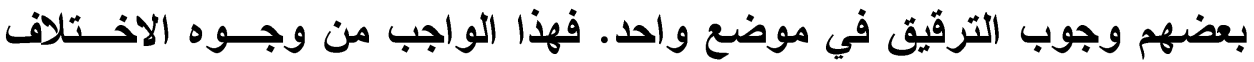

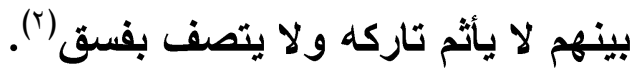

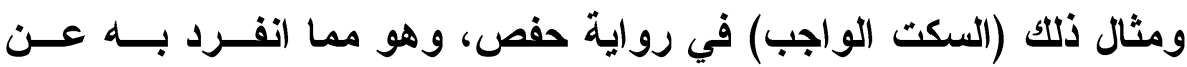

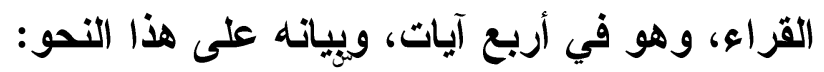

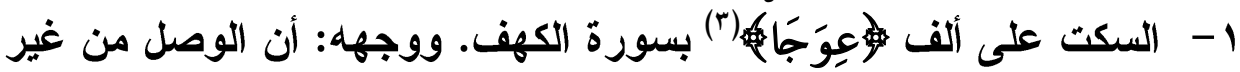

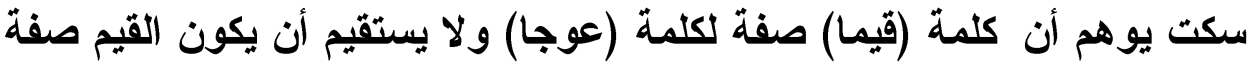
لالمعوج

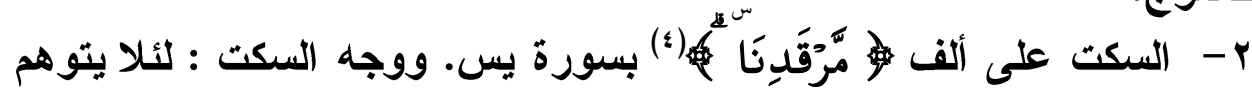

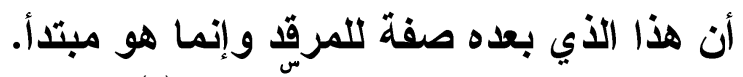

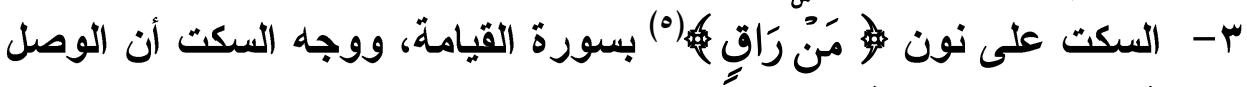

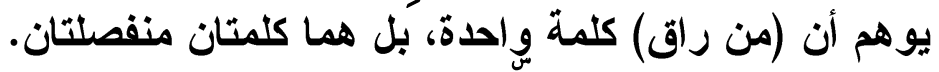

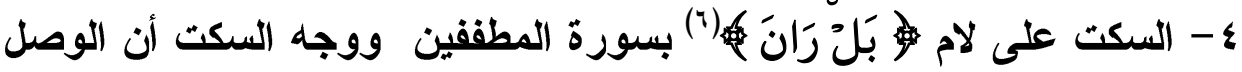

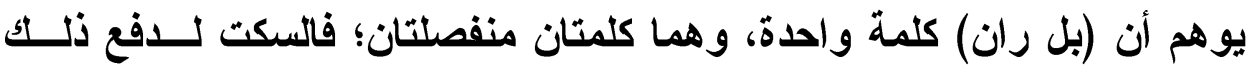

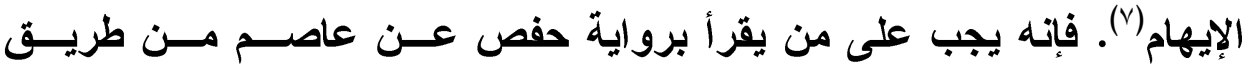

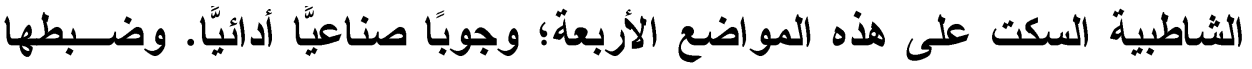

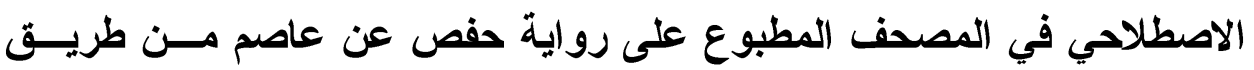

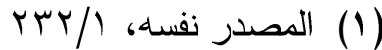

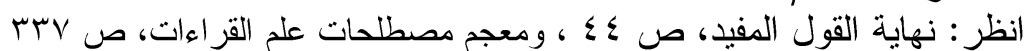

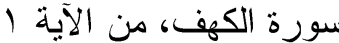

$$
\begin{aligned}
& \text { سورة يس، من الآية الآنة } \\
& \text { سورة القيامة، من الآية الآنة }
\end{aligned}
$$

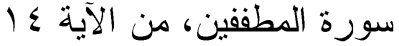

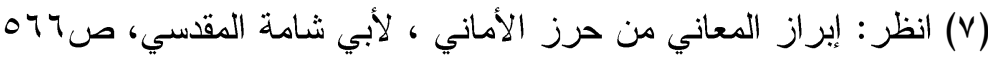


مجلة كلية الآداب، جامعة سوهاج، العدد السادس والأربعون، الجزء الأول، يناير \1 ا بم

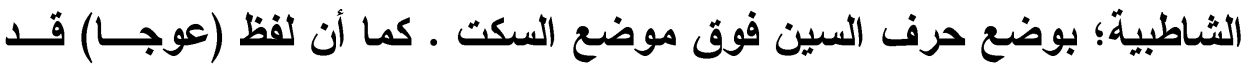
رسم من غير تنوين لمنع الوصل بالسكت عليه.

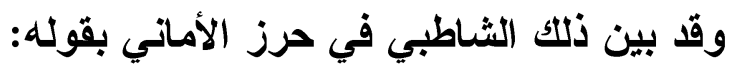

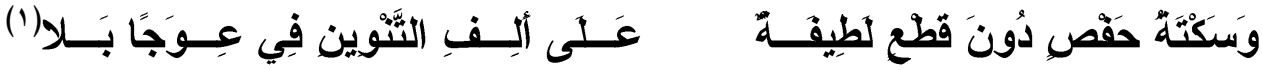

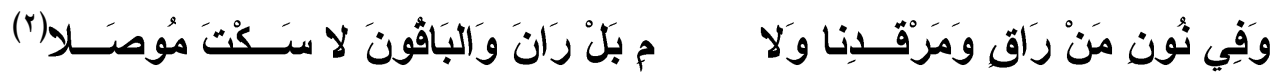
هذا ، وقد أجمل صاحب متن السلسبيل استعمالات الواجب الصناعي بقوله:

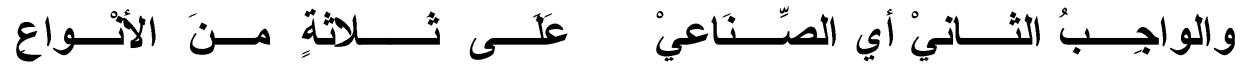

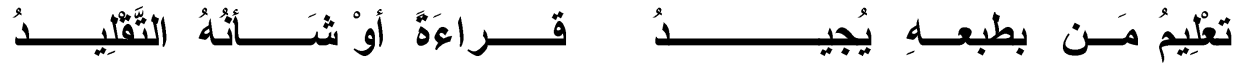

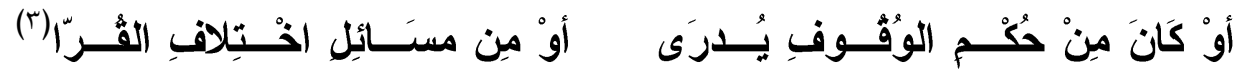

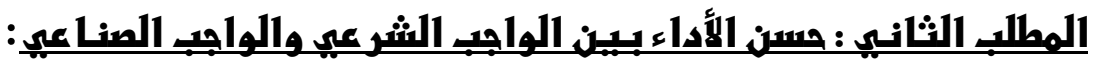
يجدر بين يدي هذا المطلب أن نتبين وجه الفرق بين الجاتب العلمي النظري

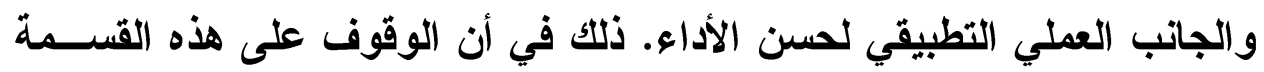

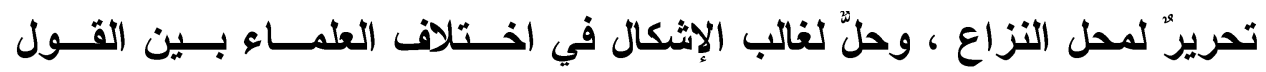

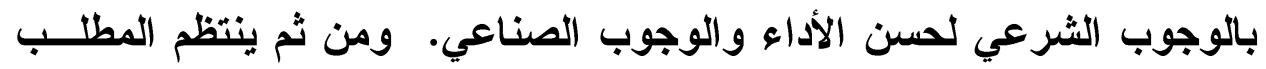
في هذين الفرعين:

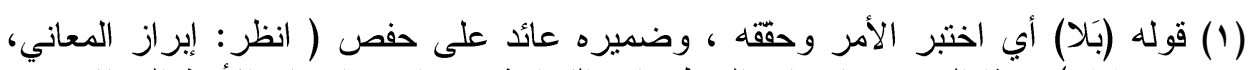

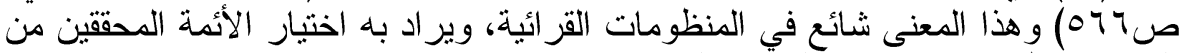
القراء، ونظيره ما جاء في المقدمة الجزية الجزية:

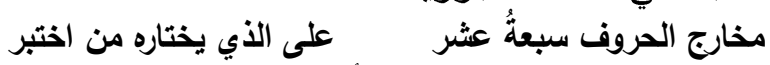

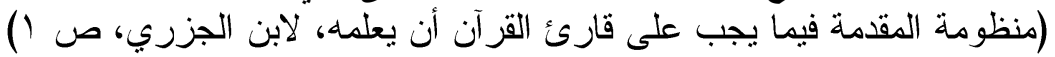

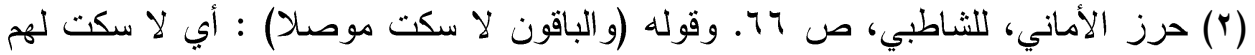

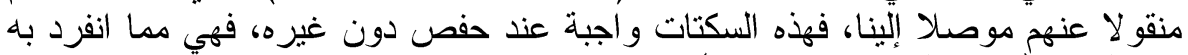

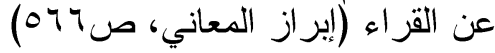

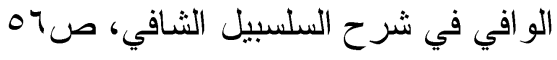




\section{(أولا) حسن الأداء (التجويد) بين النظرية والتطبيق:}

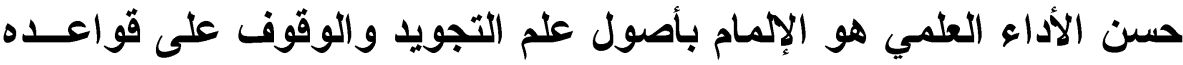
وضوابطه المسطرة في مصنفات أهل الفن. أما حسن الأداء العملي فهو تطبيث

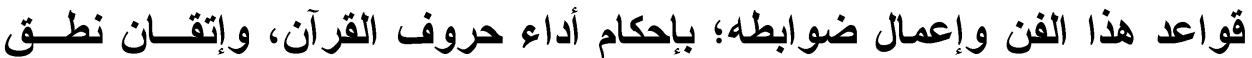

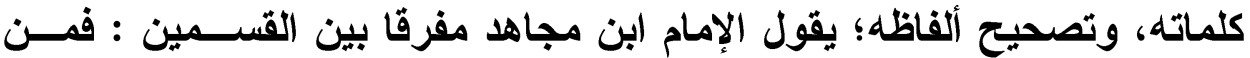

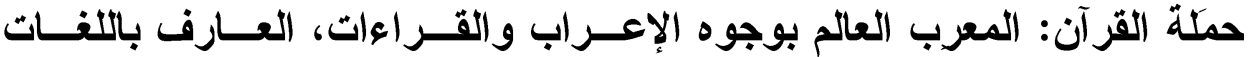

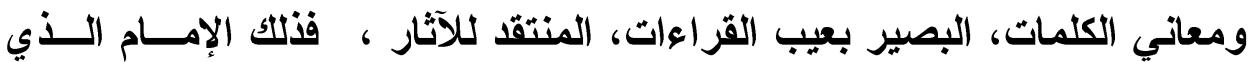

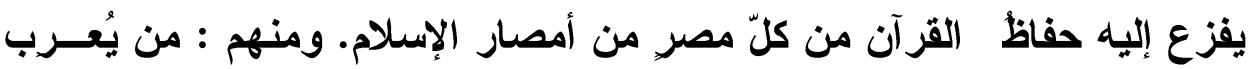

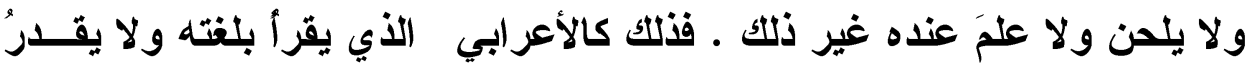

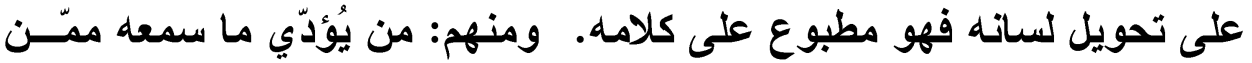

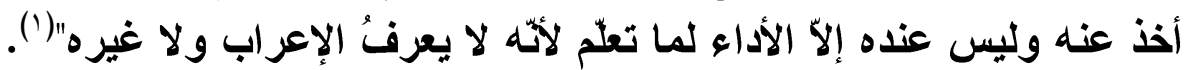

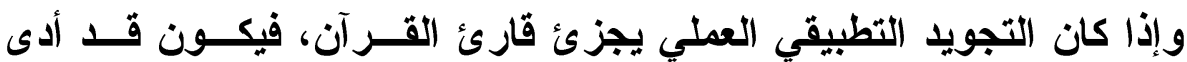
الواجب الثرعي في ترتيل القرآن وإقامة حروفه وألفاظه، على نحو ما سيتبين

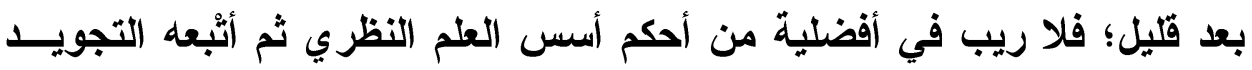

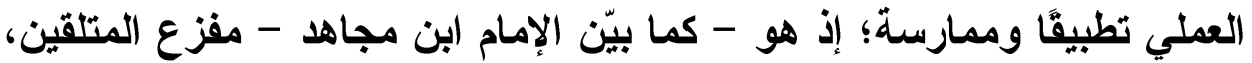

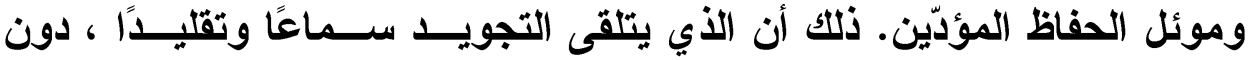

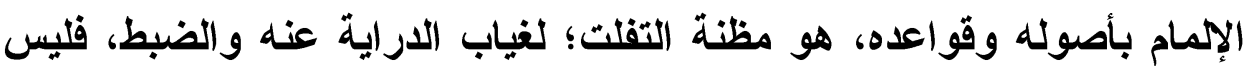

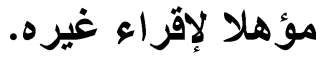

ويجلّي مكيّ بن أبي طالب القيسيّ هذه الأفضلية في معرض تميــزهـ بــين

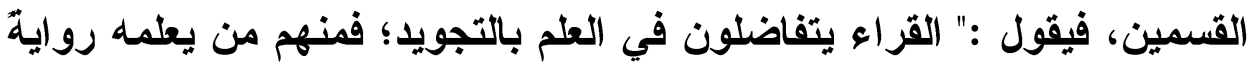

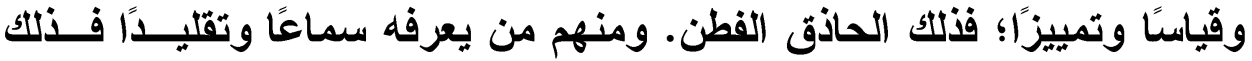

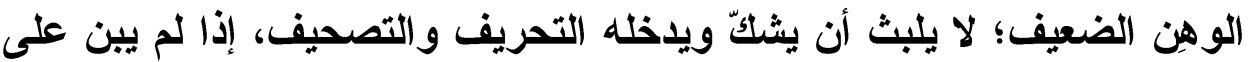
أصل، ولا نقل على فهم. فنقل القرآن فطنة ودراية أحسن منه سماعًا ورواية،

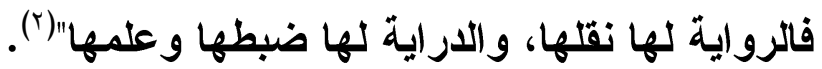


وفي كل الأحوال فلا مندوحة لقارئ القرآن عن تطبيــث قواعـــ تجويـــهـ،

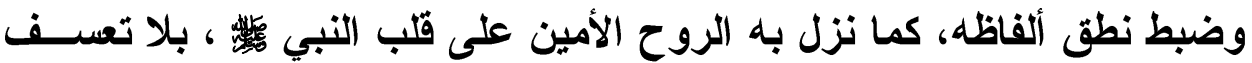

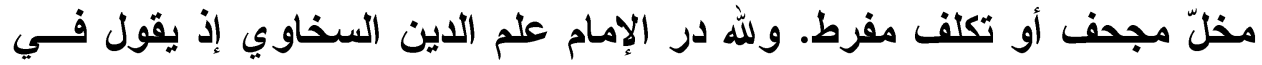

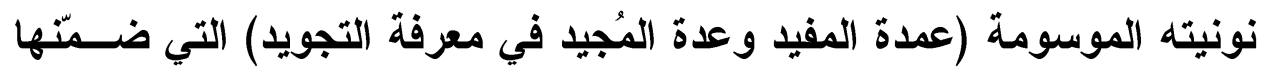
كتابه القيم (جمال القراء):

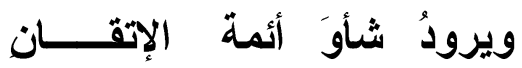

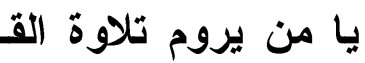

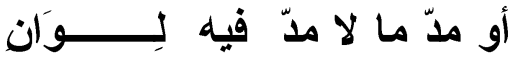

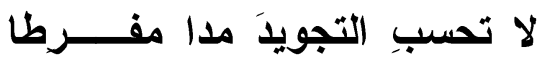

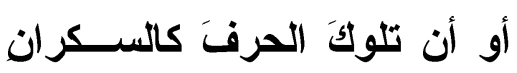

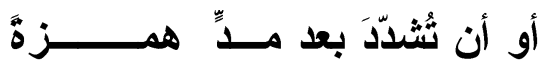

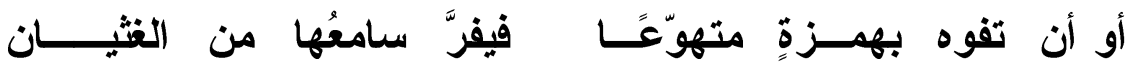

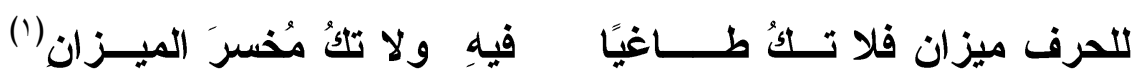
(ثانيًا) حسن الأداء (التجويد) بين الواجب الثرعي والواجب الصناعي:

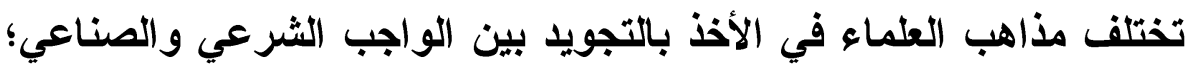

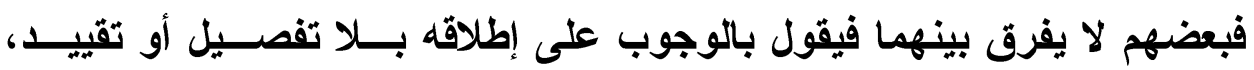

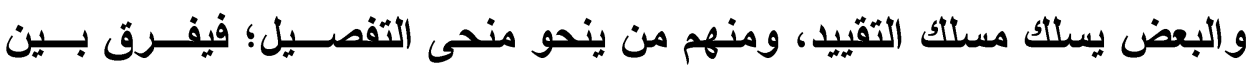
الواجب الثرعي والصناعي. وممن تناول هذه المسألة من القراع:

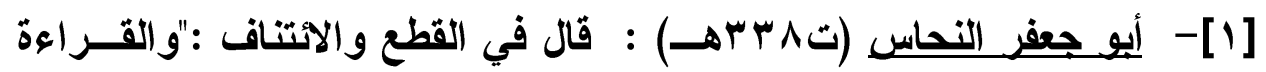

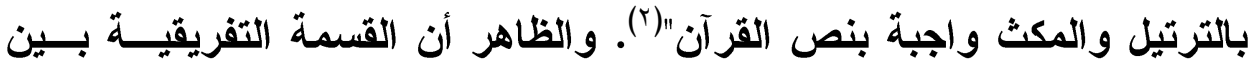

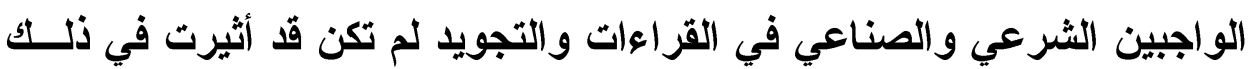

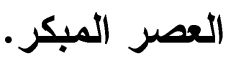

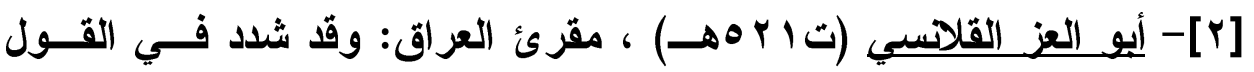

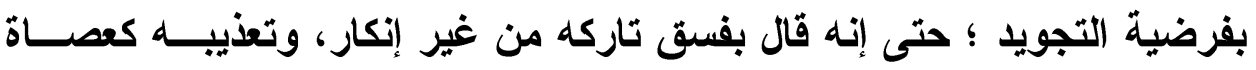

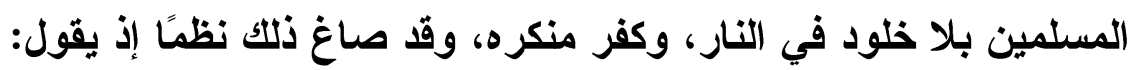

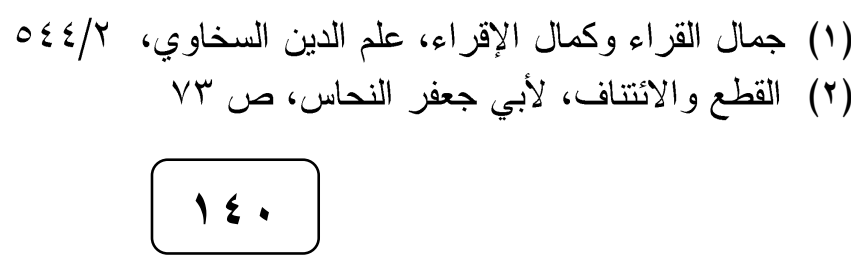


اصطلاحات الأحكام في علم القراءات وفن الأداء بين المدلول الشرعي والاستعمال الصناعي

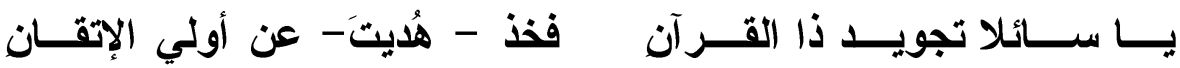

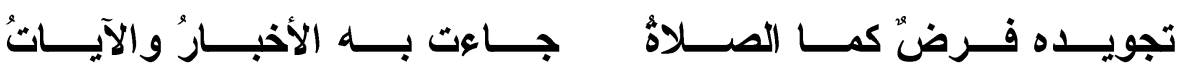

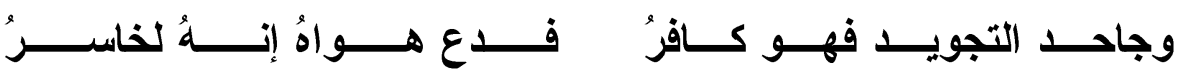

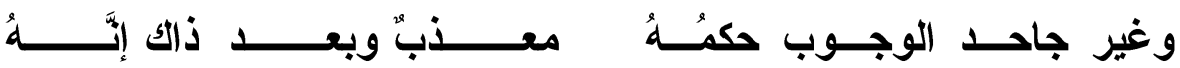

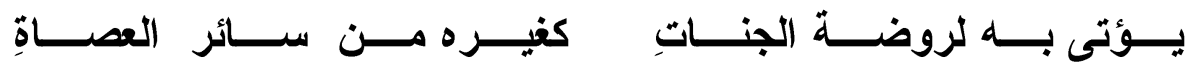

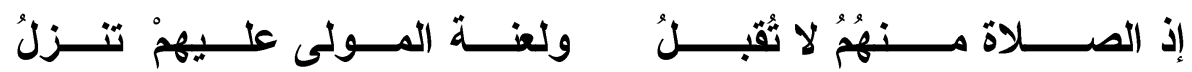

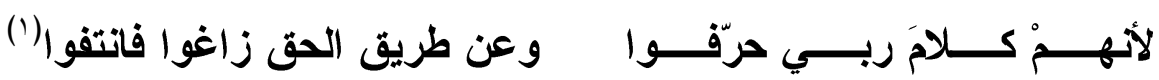

وبين يدي هذه الأبيات للإمام القلانسي ينبغي أن نقف وقفة مهمة للتفريق

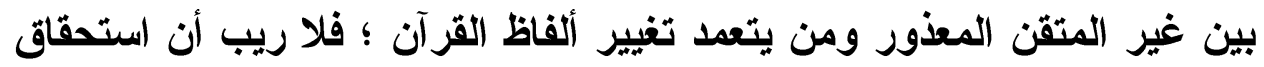
العذاب واللعن للعاصي المسلم لا يُتصور بحق من كان أميَّا غير متقدن لم لم يتمكن

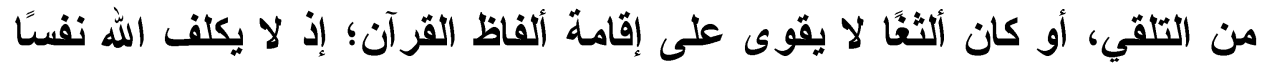

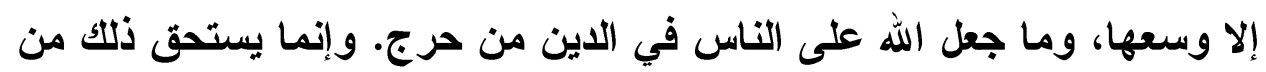
عمد إلى تغيير ألفاظ القرآن وتحريف معانيه، أو تقاعس عن عن تعلم حسن الأداء مع استطاعته.

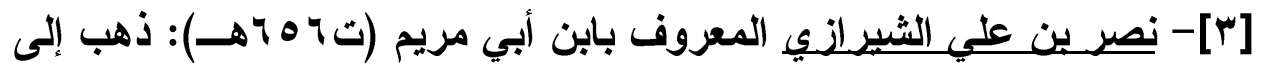

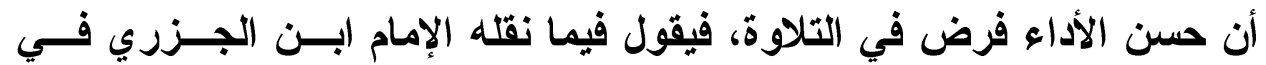

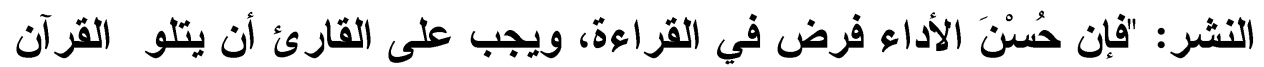

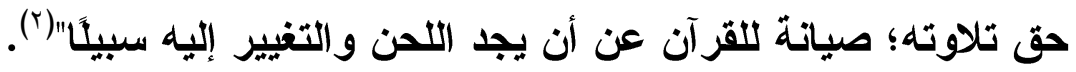

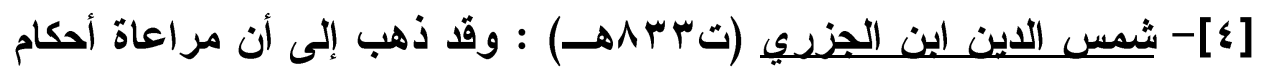

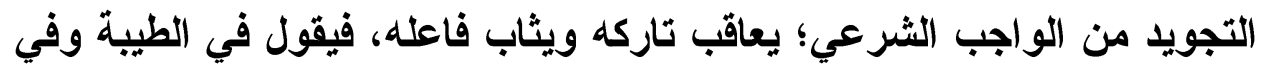

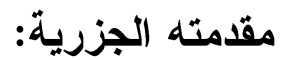

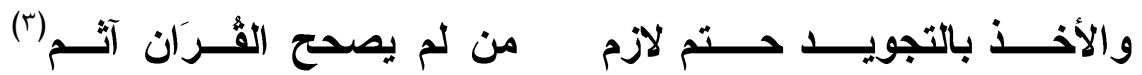

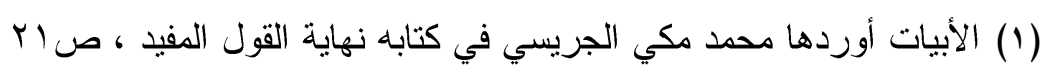

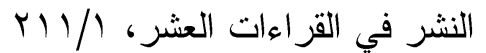

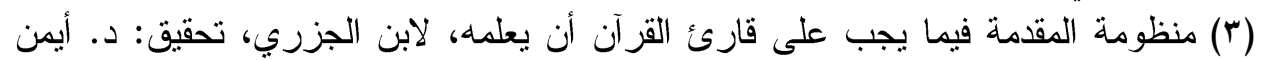
رشدي سويد، صن المنمة 


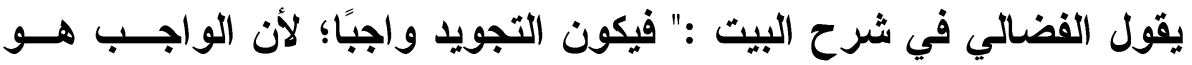

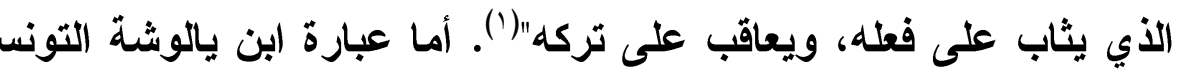

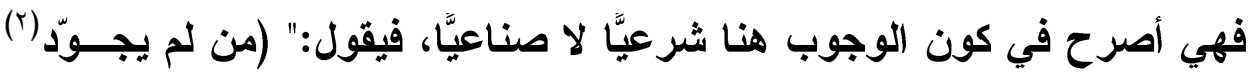

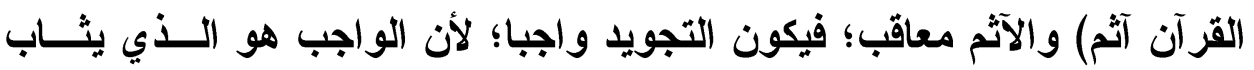

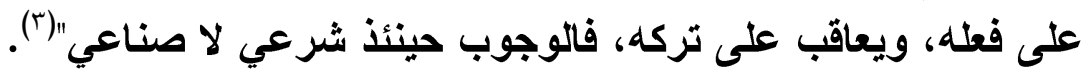

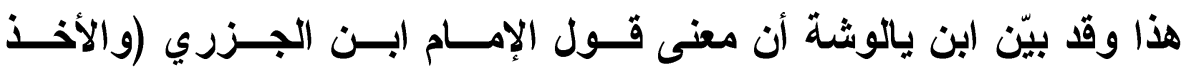

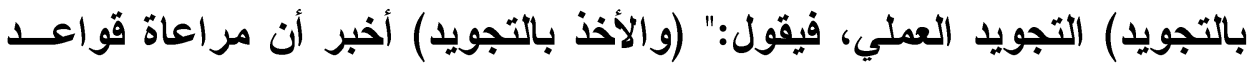

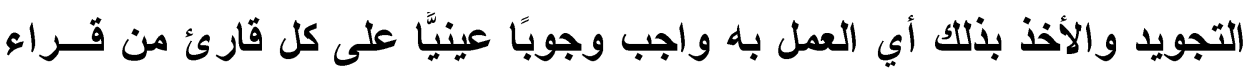

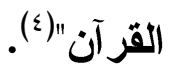

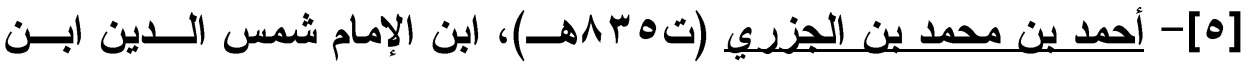

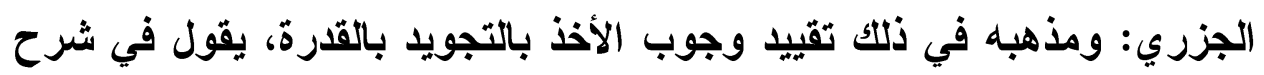

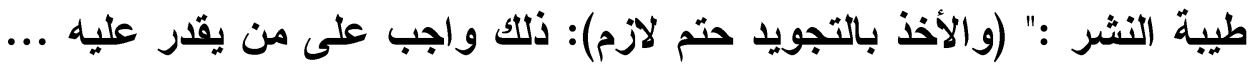

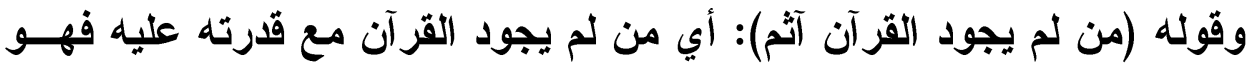

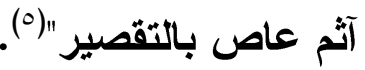

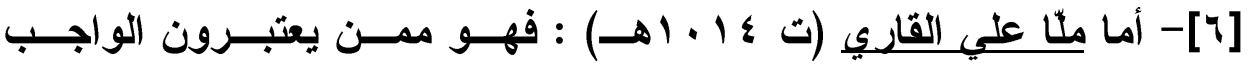

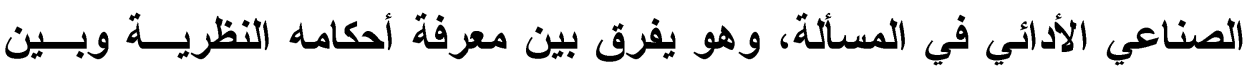

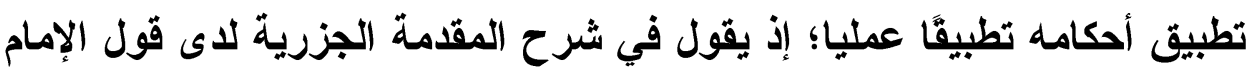

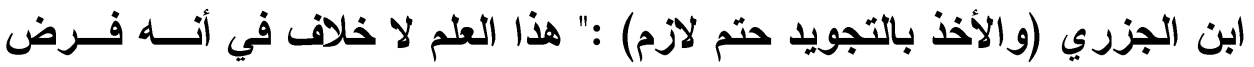

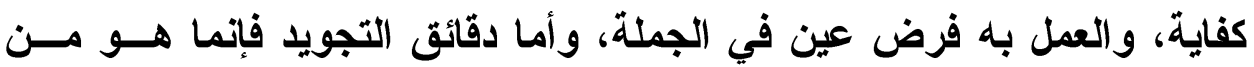

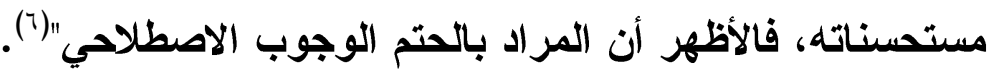

(1) الجواهر المضيّة على المقدمة الجزرية، سيف الدين بن عطاء اله الفضالي، ص.

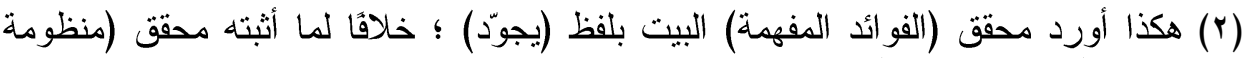

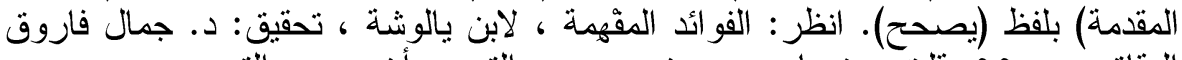

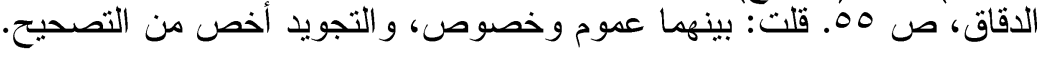

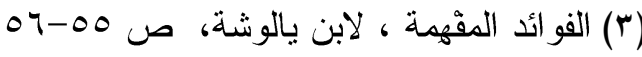

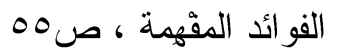

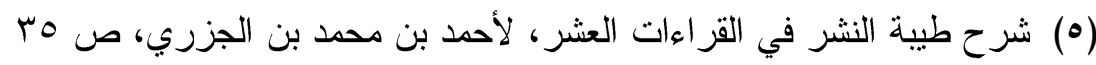

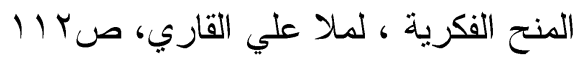


اصطلاحات الأحكام في علم القراءات وفن الأداء بين المدلول الشرعي والاستعمال الصناعي

والأي أراه راجحًا: التفصيل والتقييد في المسألة؛ فالتجويد العلمي واجـبـ

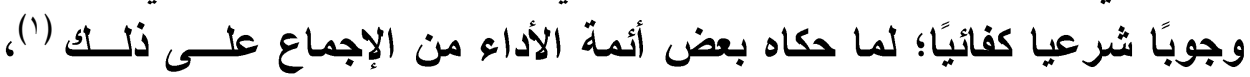

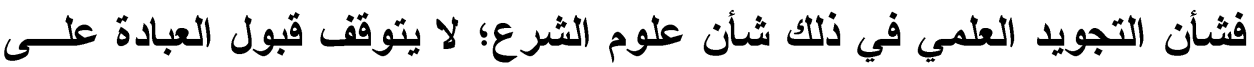
معرفتها.

أما التجويد العملي فهو واجب وجوبًا شرعيًّا عينيًا على من يقدر عليه تلقيًا

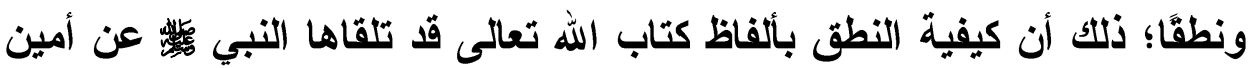

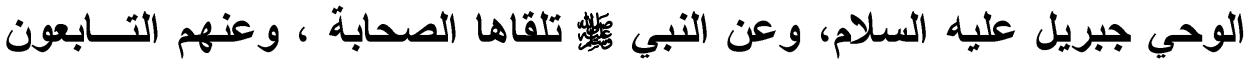

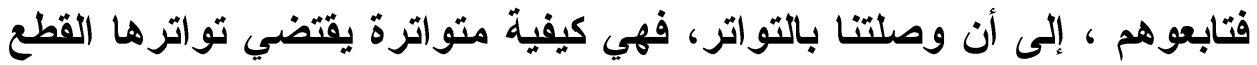

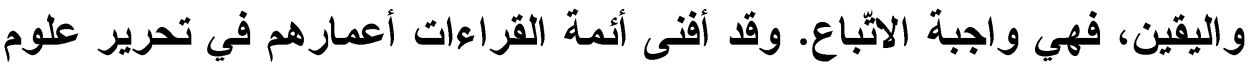

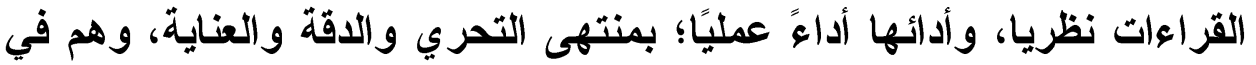

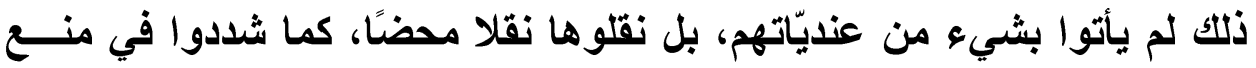
القياس في القراعة ، فهم على نحو ما قال الشاطبي:

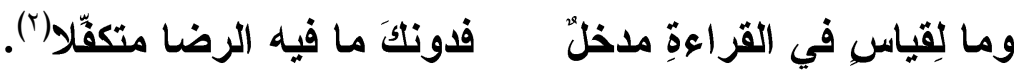
والوجوب الثرعي العيني للتجويد العملي مقيد بالقدرة على التلقي والنطق. ويلال على التقييد ما أخرجه الثيخان من حديث عائشة ل أنها قالت: قال رسئ رسول الله

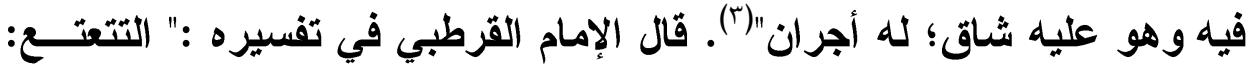

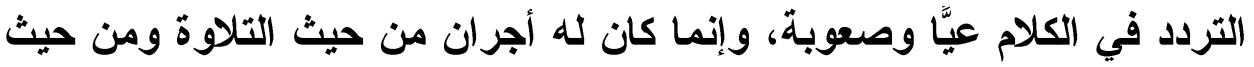

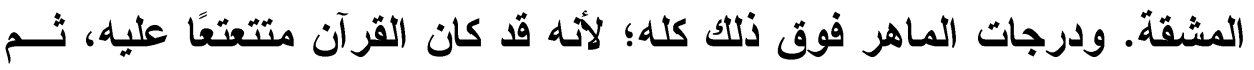

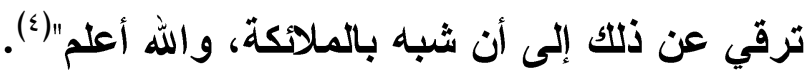

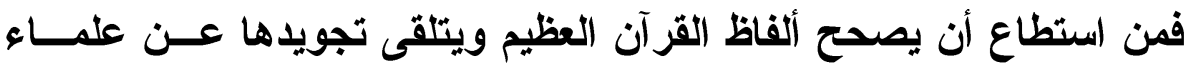

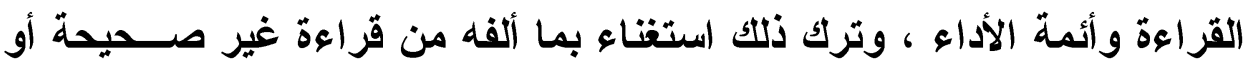

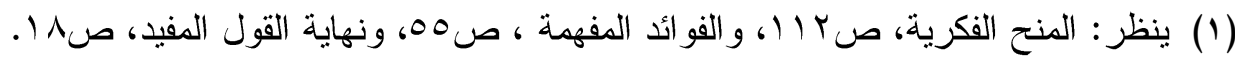

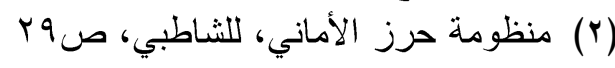

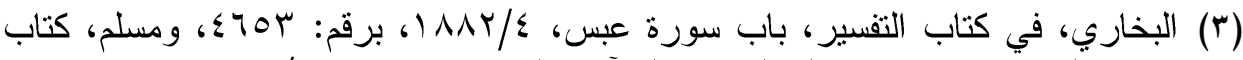

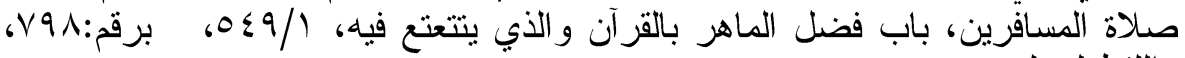
و اللفظ لمسلد.

$$
\text { الجامع لأحكام القرآن، للقرطبي، V/1 }
$$


استنكاقًا عن الرجوع إلى أهل الاختصاص؛ كان آثمًا فاسقًا مستحقًا لعقــاب الله تعالى.

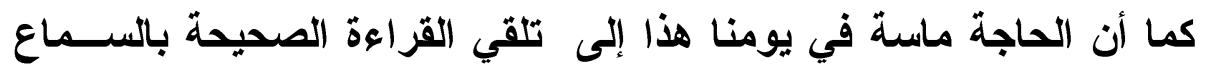

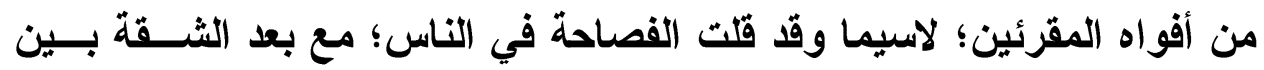

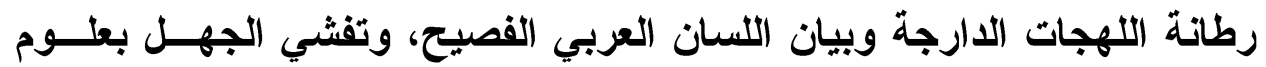

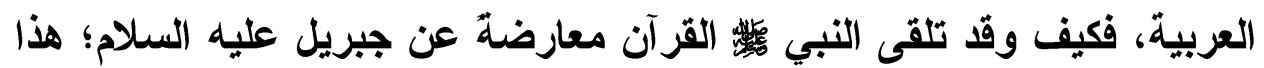

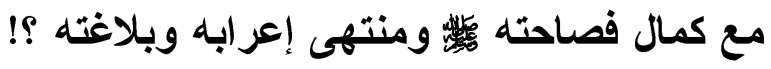

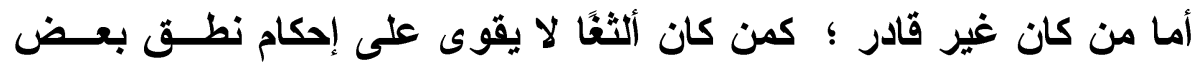
الحروف أو من لم يجد من يتلقى عليه قواعد النطق الصحيح، لا سيما من كان

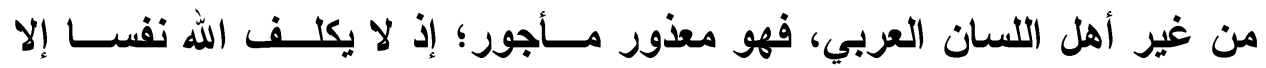
وسعها.

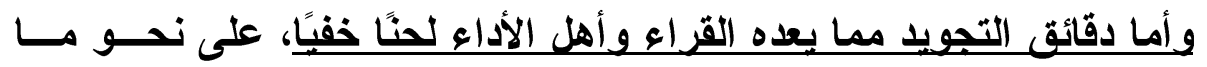

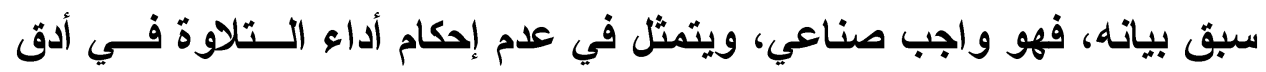

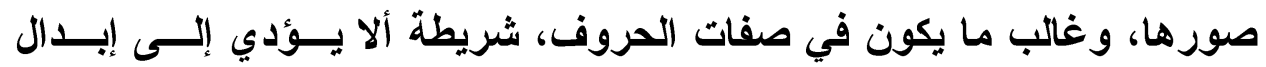

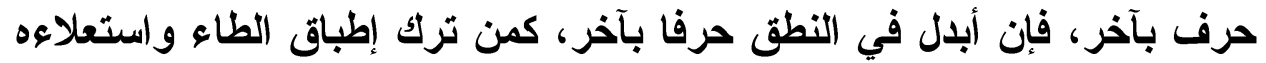

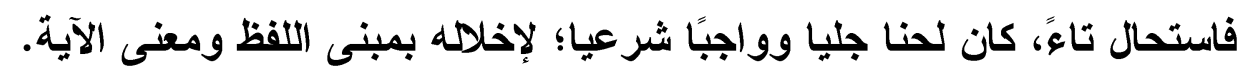

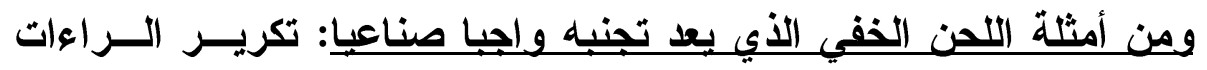

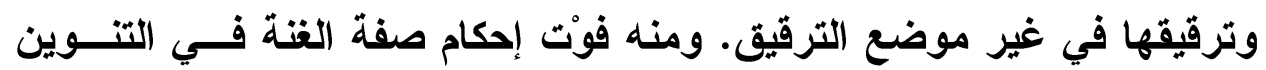

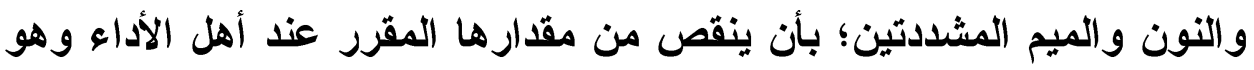

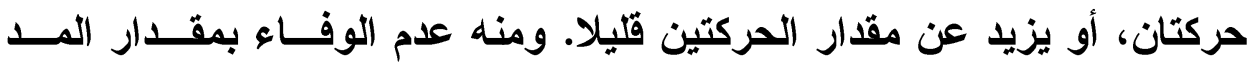
الكلازم؛ بأن يجعله خمس حركات، والمقرر عند أهل الأداء ست. ومنه أيضَّــا:

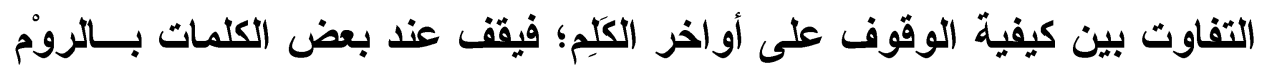

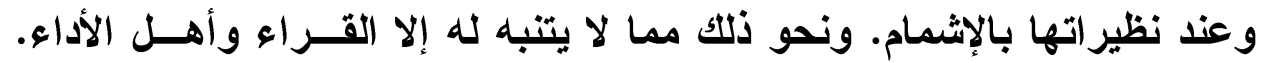

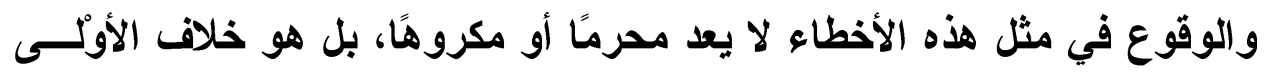

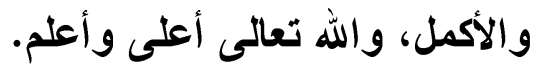




\section{اصطلاحات الأحكام في علم القراءات وفن الأداء بين المدلول الشرعي والاستعمال الصناعي}

\section{النماتنهة}

وفي ختام الاراسة، أسجل أهم النتائج والتوصيات، وتتمثل فيما يأتي:

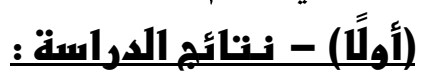

ا - مؤدى مصطلح (الواجب الثرعي) ، على اختلاف تعاريفه واستعمالاته عند

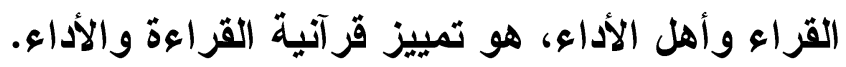

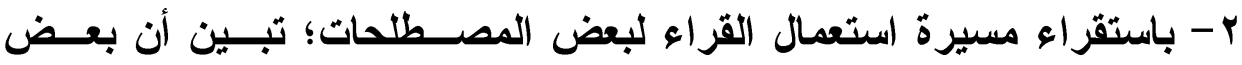

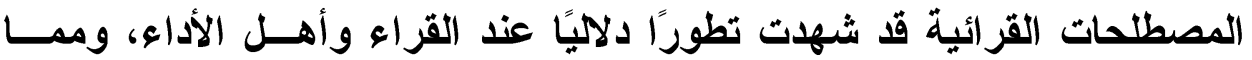

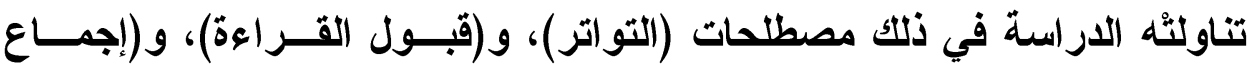

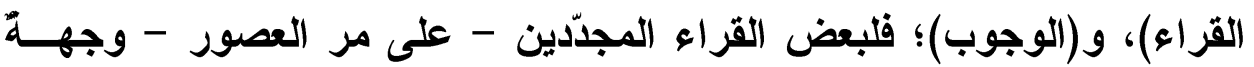
مصطلحية هو موليها، في سبيل تقعيد وتقريب علم القراعات القات القر آنية.

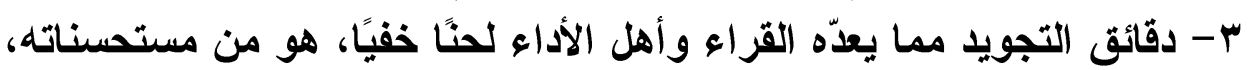

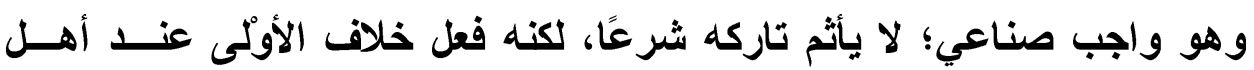

\section{(ثانيًاً) - التنوصيات:}

ا - أوصي الباحثين بالعناية بقضايا المصطلح في العلوم الثرعية؛ عناية تصل

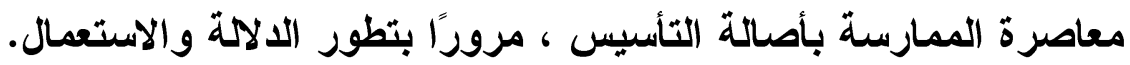

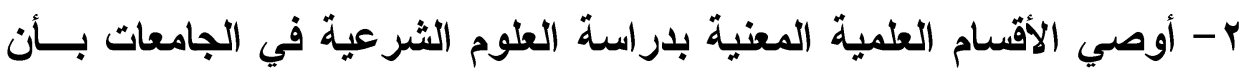

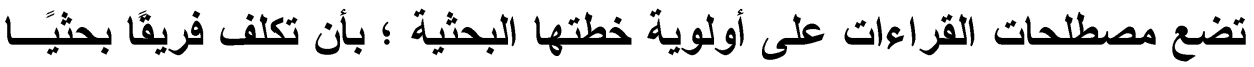

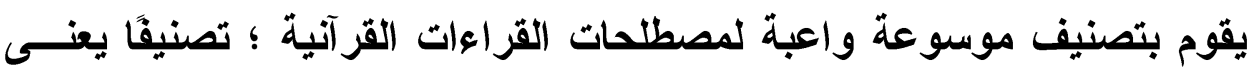

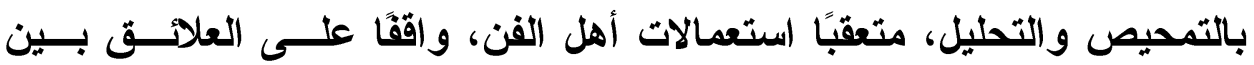

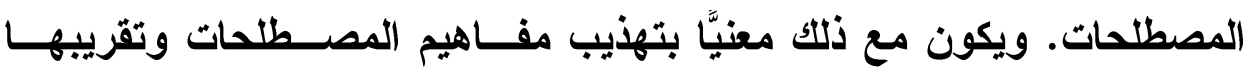




\section{المصادر والمراجيه:}

(أوبًا)(1-)

ا. ـ الإبانة عن معاني القراعات، لمكيّ بن أبي طالب القيسيّ، تحقيق: عبـــ

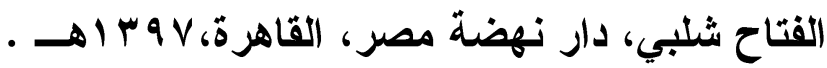

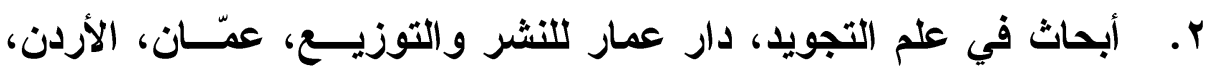

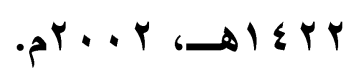

r. إبراز المعاني من حرز الأماني، عبد الرحمن بن إسماعيل بن إبراهيم

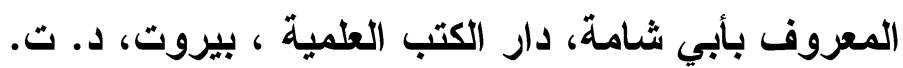

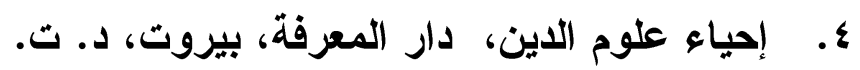

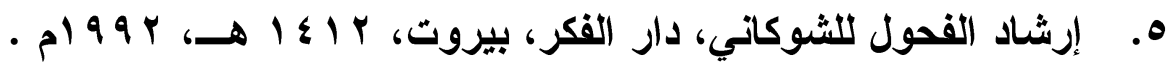

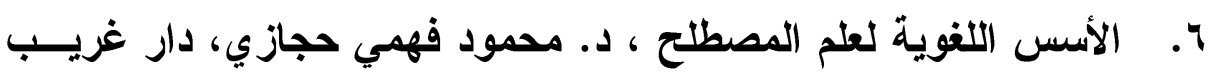

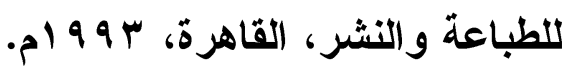

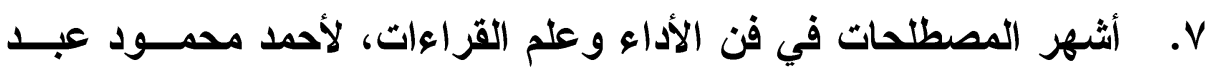

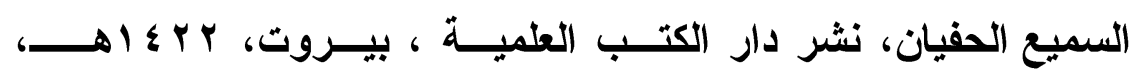

$$
\text { . } 1
$$

^. أصول السرخسي، محمد بن أحمد بـن أبــي ســهل شــــ الأثمــة

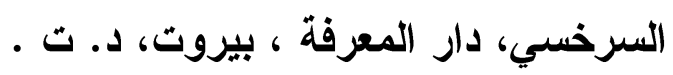

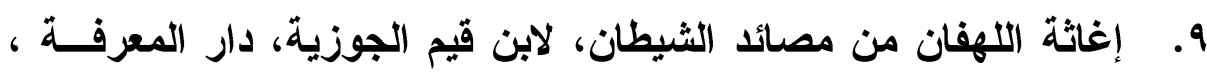

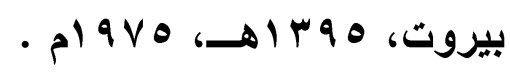

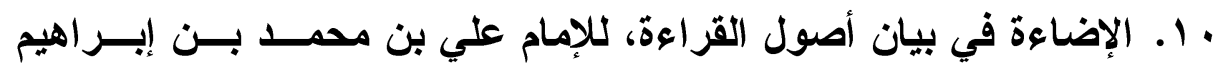

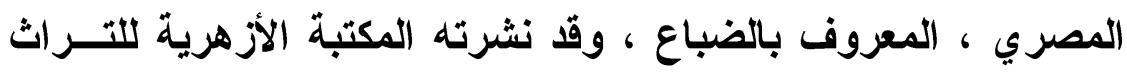

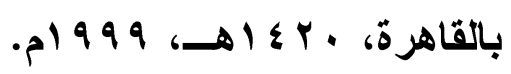

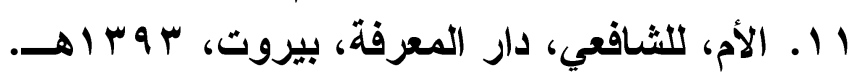

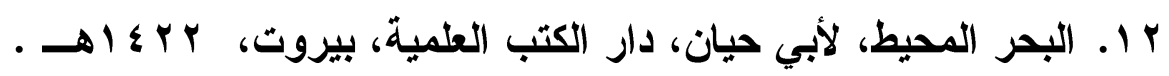

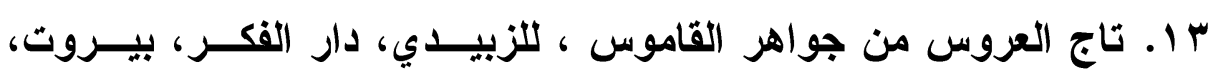

$$
\text { - } 1 \text { \& }
$$

ع ا. تحفة المحتاج في شرح المنهاج، لابن حجر الهيتمي، المكتبة التجارية

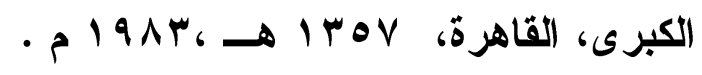


ه ـ. التعريفات، علي بن محمد بن علي الجرجـــي، دار الكتــاب العربــي،

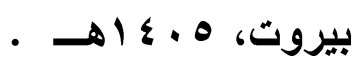

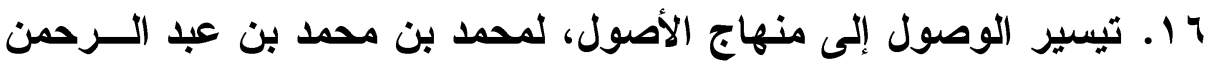

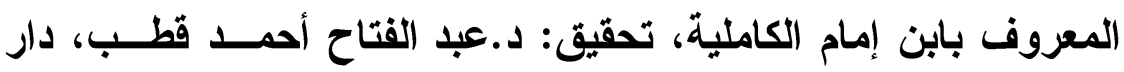

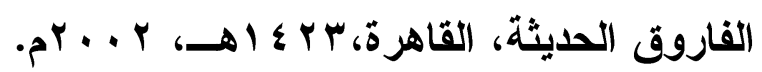

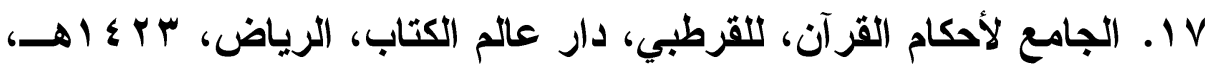

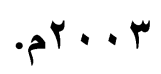

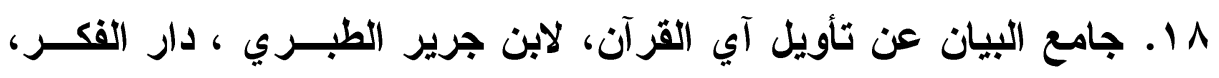

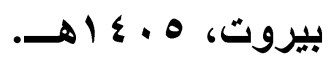

9 1 . جامع البيان في القراعات السبع المشهورة، لأبي عمرو الداني، تحقيق:

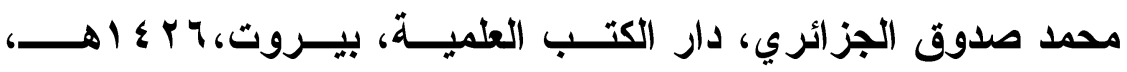

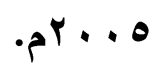

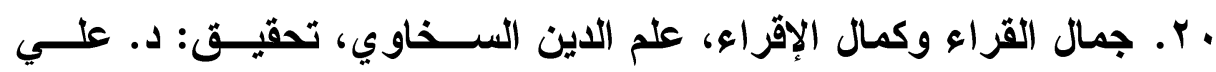

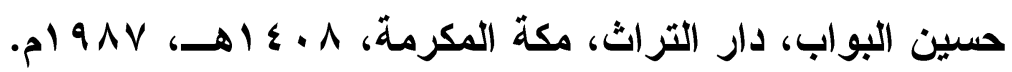

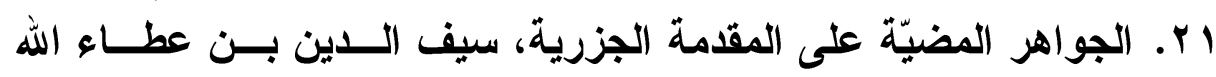

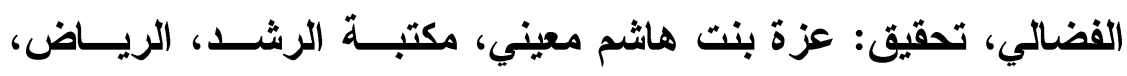

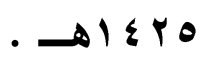

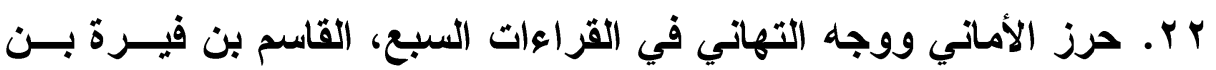

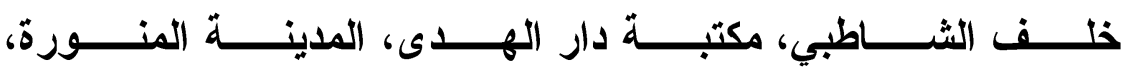

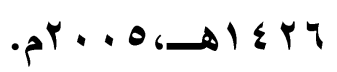

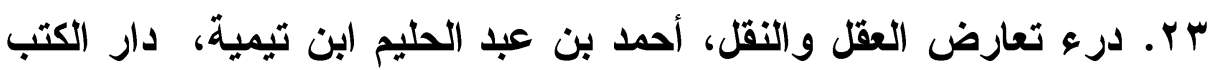

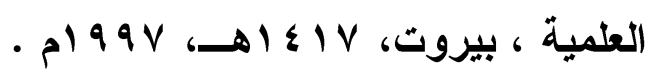

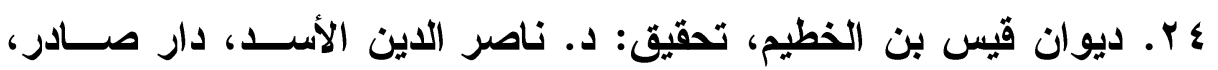

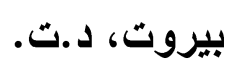

ه r. الرعاية لتجويد القراعة وتحقيق لفظ التلاوة، مكي بن أبي طالــب، دار

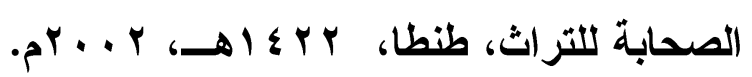

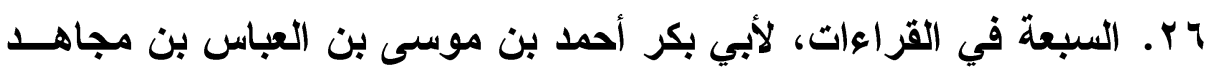

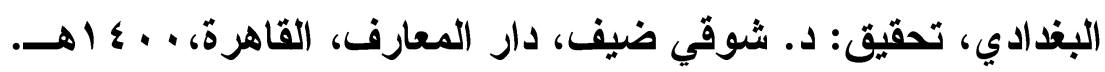


rV . . سلسلة الأحاديث الصحيحة، محمد ناصر الاين الألباني، مكتبة المعارف ه

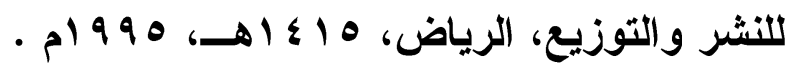

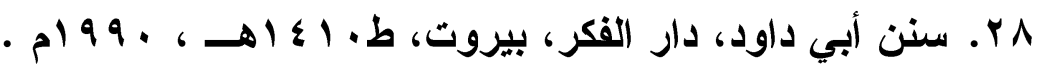

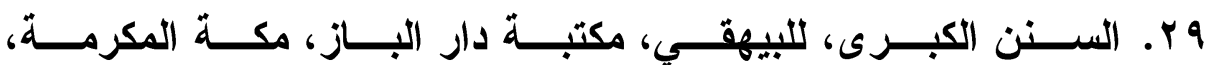

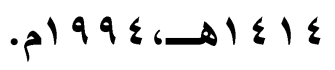

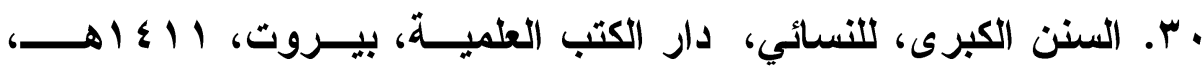

$$
\text { - 1991 }
$$

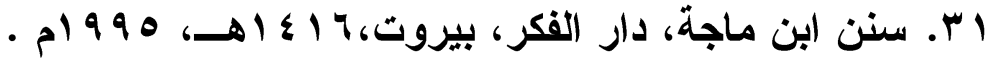

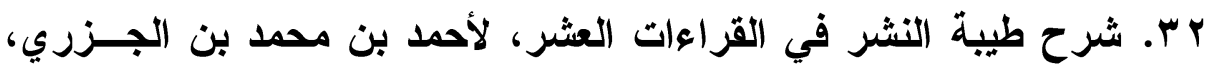

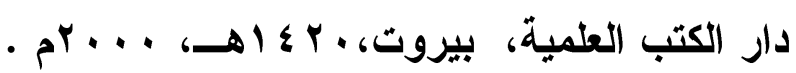

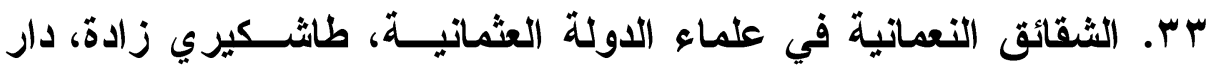

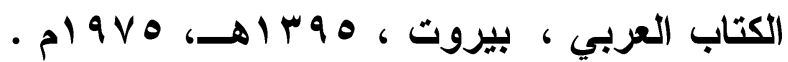

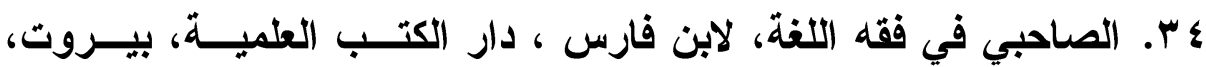

$$
\text { - } 99 \mathrm{~V} \text { أه }
$$

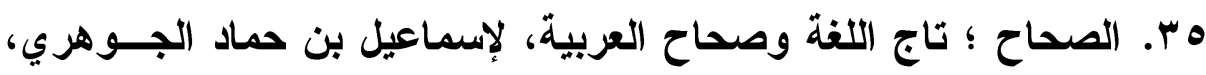

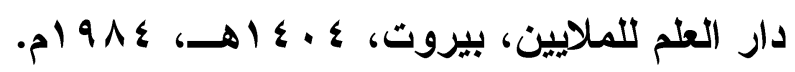

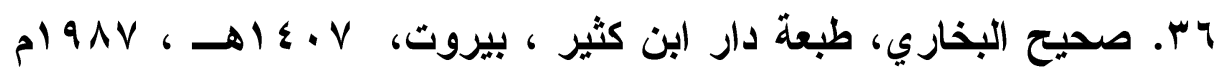

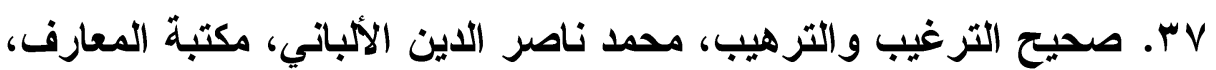

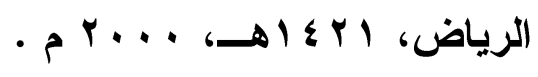

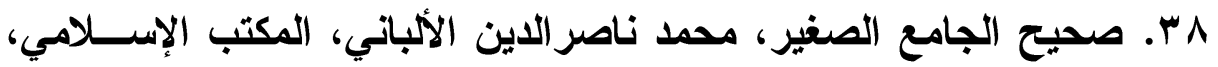

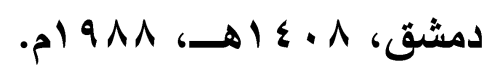

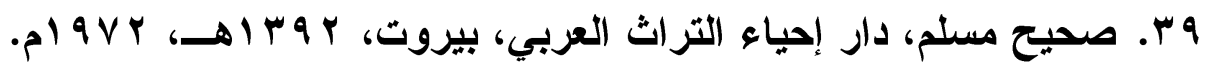

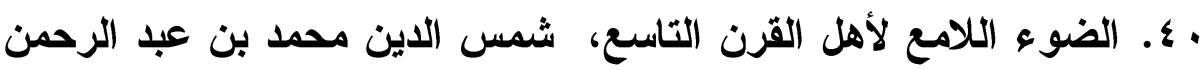

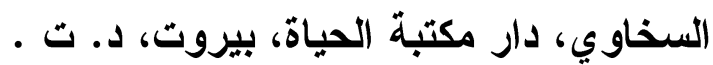

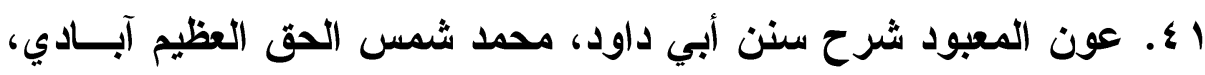

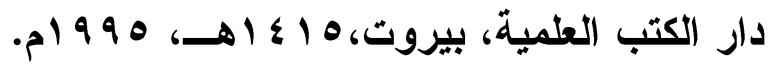


اصطلاحات الأحكام في علم القراءات وفن الأداء بين المدلول الشرعي والاستعمال الصناعي

r ع. غاية النهاية في طبقات القزاء، لابن الجـزري، مكتبــة ابـن تيميــة،

القاهرة.

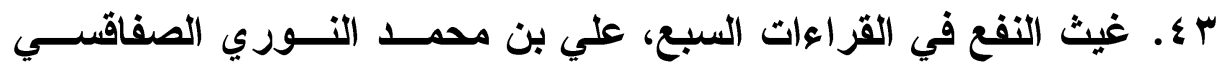

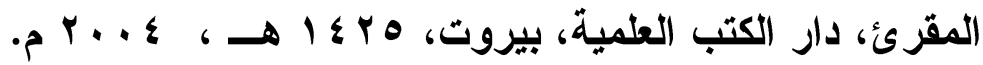

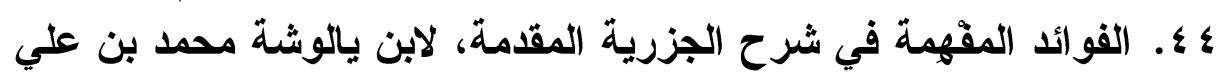

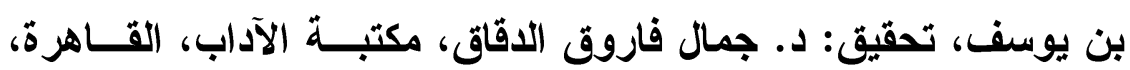

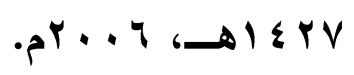

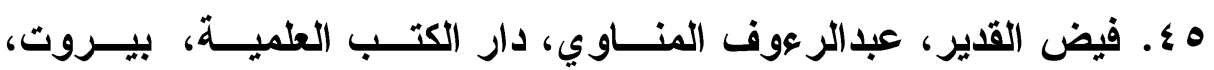

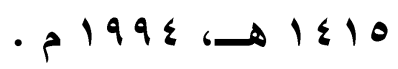

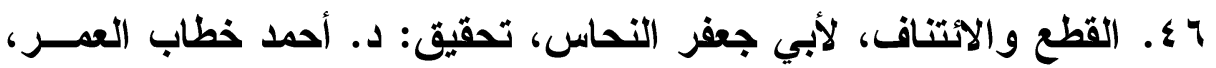

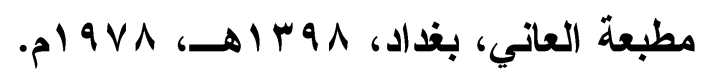

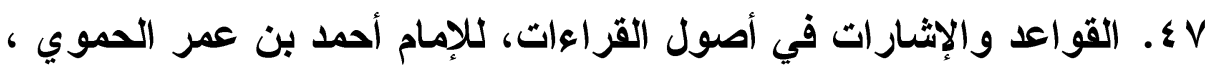

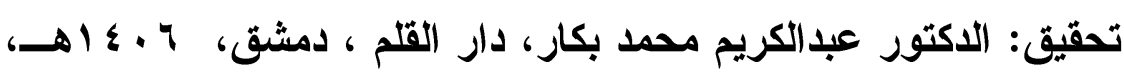

$$
\text { م } 917
$$

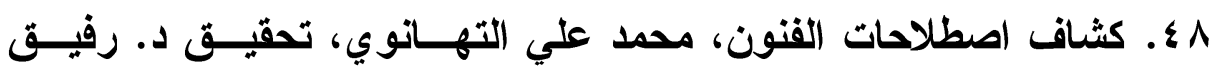

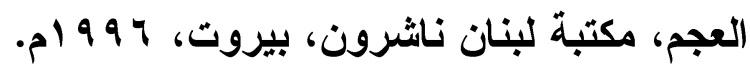

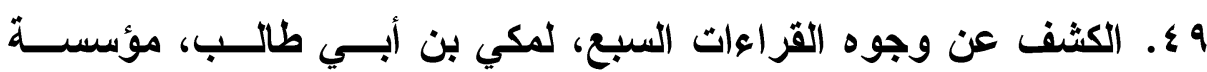

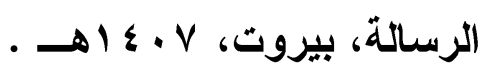

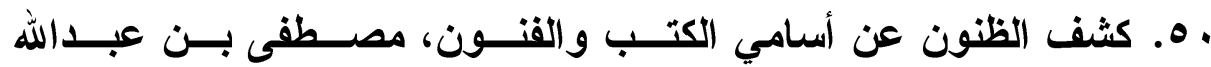

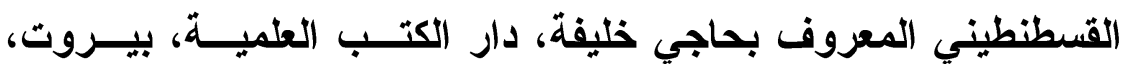

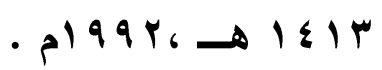

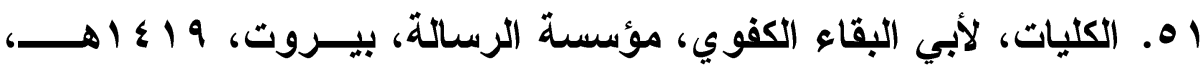

$$
\text { - م) } 991
$$

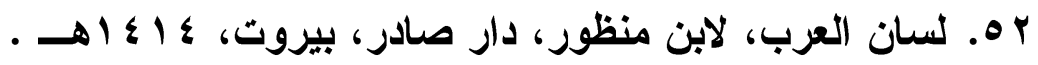

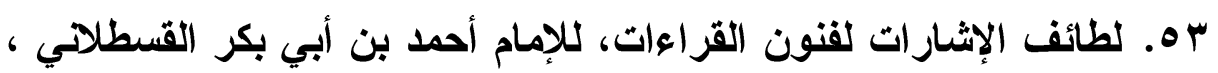

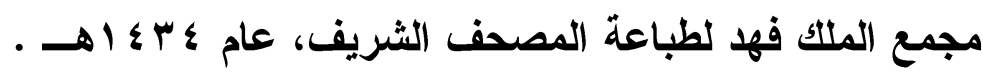

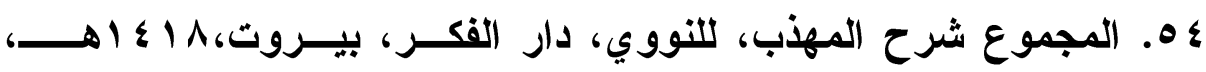




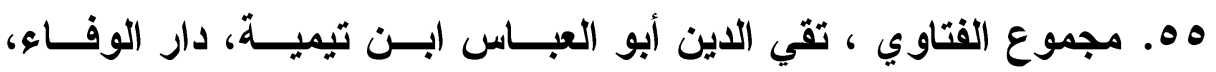

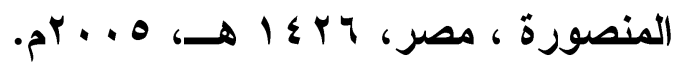

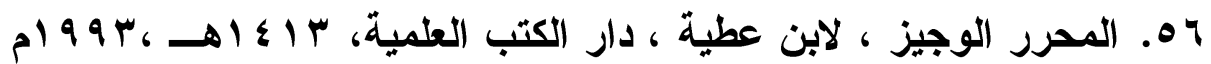

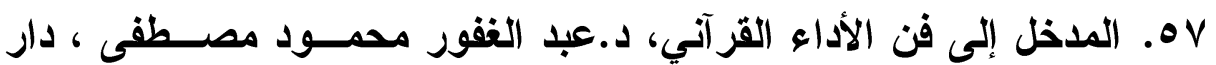

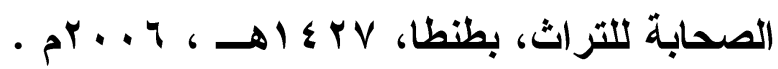

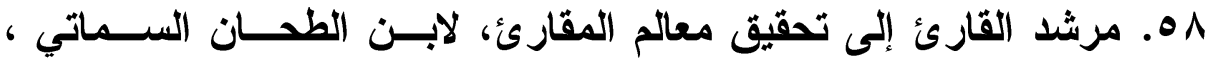

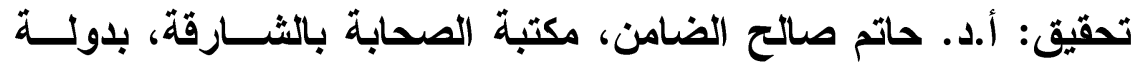

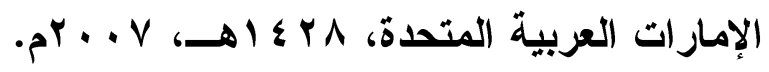

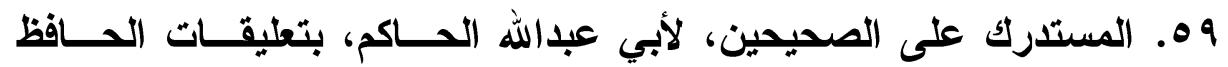

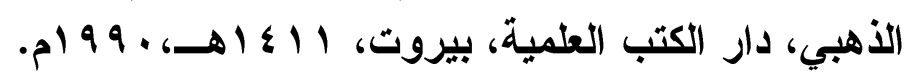
• 7. ه ا 7. مسند الإمام أحمد، مؤسسة قرطبة، القاهرة، د.ت.

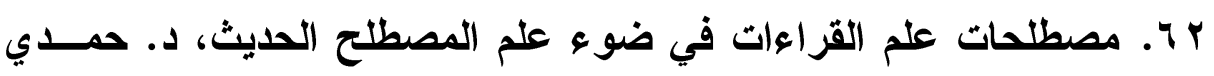

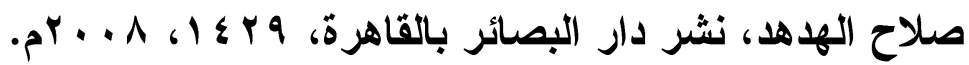

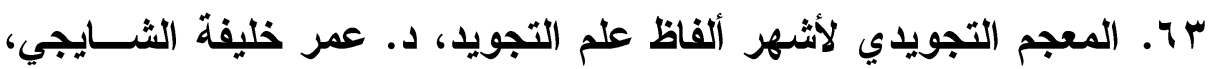

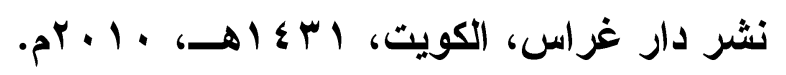

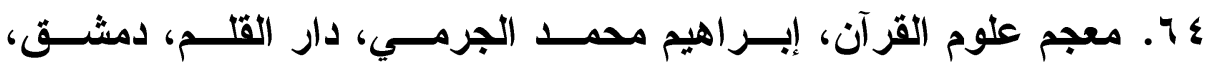

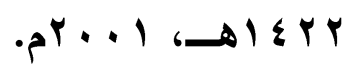

ه 7. معجم مصطلحات علم القراعات القرآنية وما يتعلق به، أ.د. عبد العلي

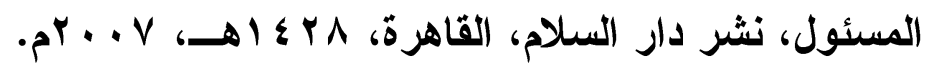
ד 7.

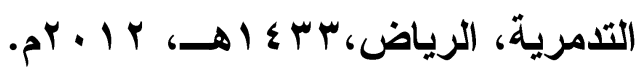
TV

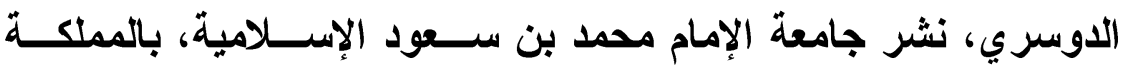

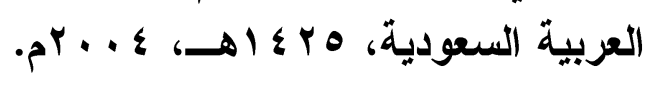

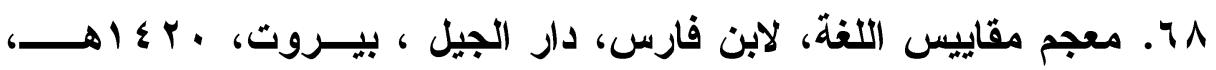




\section{اصطلاحات الأحكام في علم القراءات وفن الأداء بين المدلول الشرعي والاستعمال الصناعي}

9 7. المعجم الوسيط، مجمع اللغة العربية بالقاهرة، مكتبة الثروق الدولية،

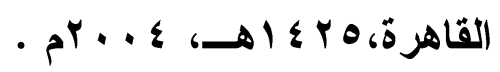

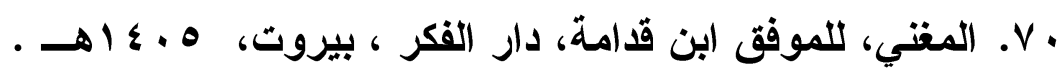
V. المغني في أصول الفقه، لجلال الادين عمر بن محمد الخبازي، دارئ تحقيق:

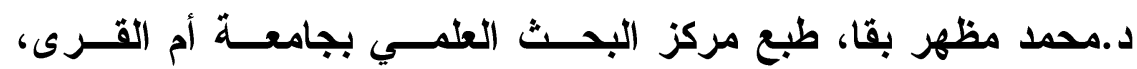

$$
\rightarrow \varepsilon \cdot r
$$

r V V مفتاح دار السعادة ، لابن القيم، دار الكتب العلمية ، بيروت، د.ت.

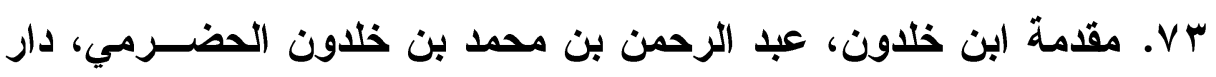

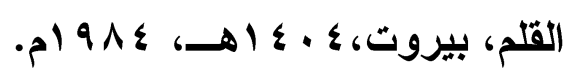

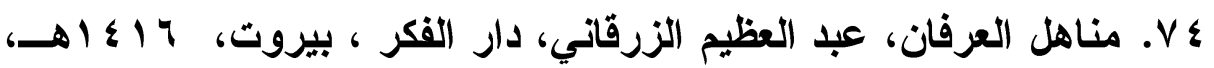

$$
\text { . } 1997
$$

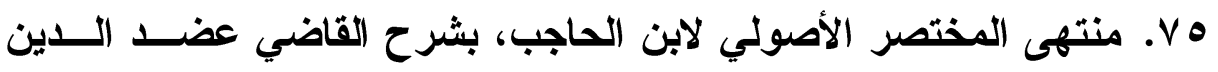

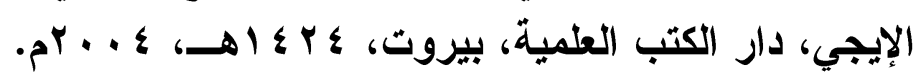

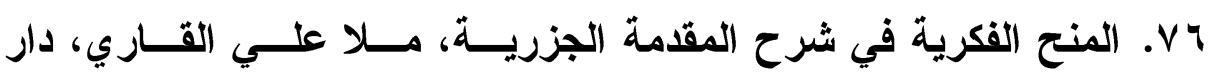

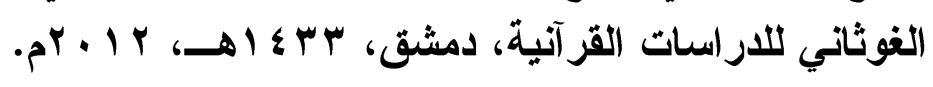

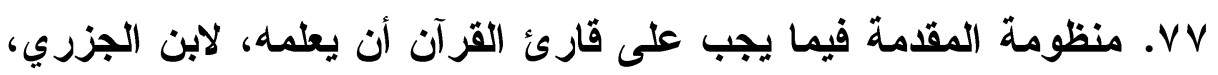

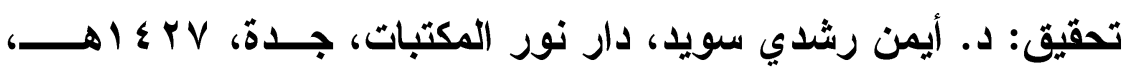

$$
\text { . } 7
$$

^^. منهاج الوصول إلى علم الأصول، قاضي القضاة عبـــ الله بـن عمـر

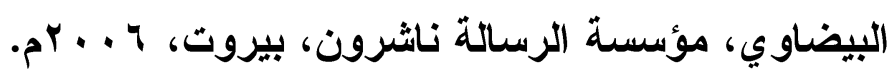

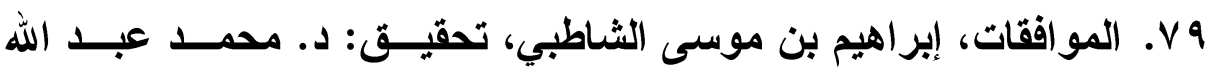

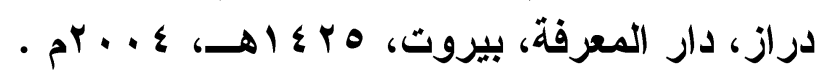

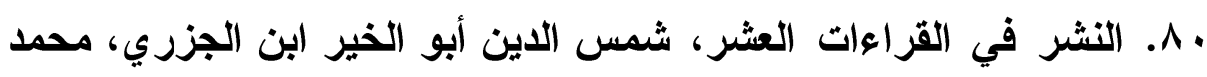

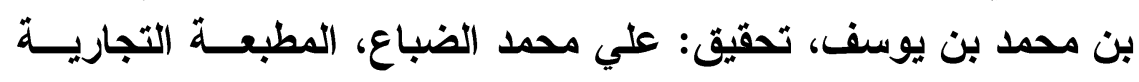

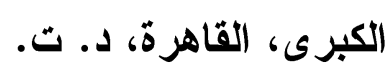

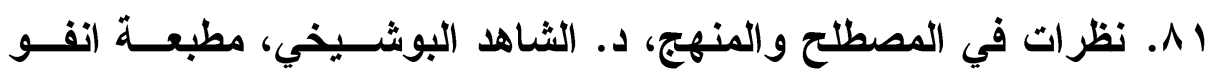

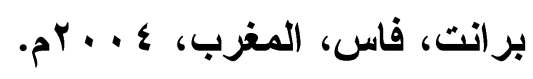


r ـ. نهاية السول، لجمال الاين عبد الرحيم الإسنوي، عالم الكتب ، بيروث، د. ث.

بـ. نهاية القول المفيد في علم التجويد، محمد مكــي الجريسـي ، مكتبــة

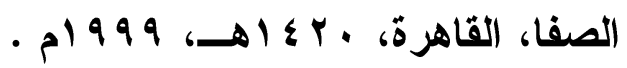

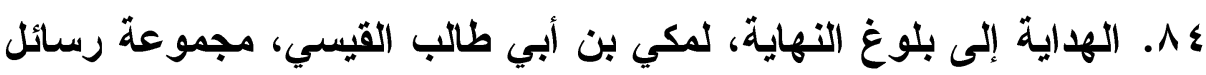

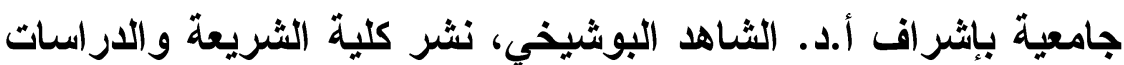

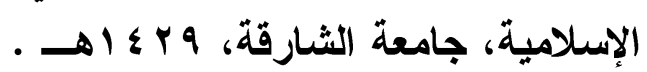

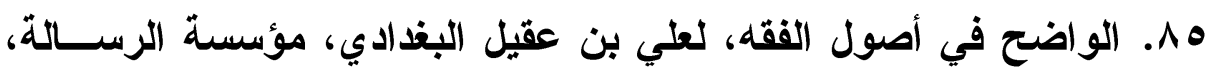

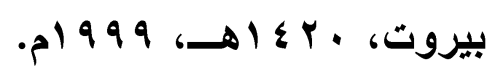

\ 1. الوافي في شرح السلسبيل الثافي في علم التجويد، لعثمان بن سليمان

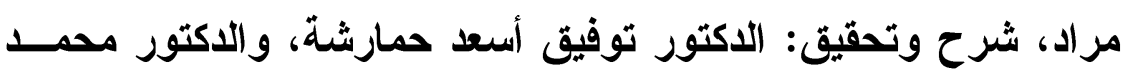

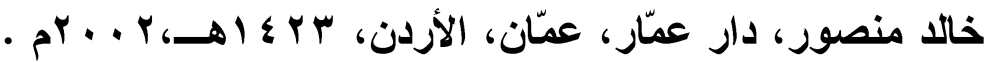

\section{(ثانبيًا) - الدوربيات :}

1. بحث بعنوان: (كتاب التتبيه على اللحن الجلي واللحن الخفــي، لأبــي

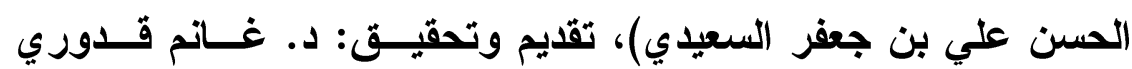

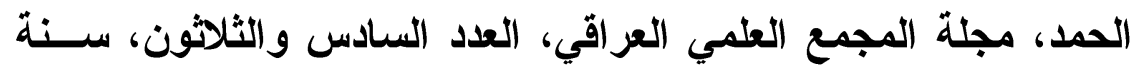
- $19 \wedge 0$ 